\title{
Prediction of Maximum Scour Depth Using Scaled Down Bridge Model in a Laboratory
}

\author{
Rupayan Saha
}

Follow this and additional works at: https://researchrepository.wvu.edu/etd

\section{Recommended Citation}

Saha, Rupayan, "Prediction of Maximum Scour Depth Using Scaled Down Bridge Model in a Laboratory" (2017). Graduate Theses, Dissertations, and Problem Reports. 6556.

https://researchrepository.wvu.edu/etd/6556

This Thesis is protected by copyright and/or related rights. It has been brought to you by the The Research Repository @ WVU with permission from the rights-holder(s). You are free to use this Thesis in any way that is permitted by the copyright and related rights legislation that applies to your use. For other uses you must obtain permission from the rights-holder(s) directly, unless additional rights are indicated by a Creative Commons license in the record and/ or on the work itself. This Thesis has been accepted for inclusion in WVU Graduate Theses, Dissertations, and Problem Reports collection by an authorized administrator of The Research Repository @ WVU. For more information, please contact researchrepository@mail.wvu.edu. 


\title{
Prediction of Maximum Scour Depth Using Scaled Down Bridge Model in a Laboratory
}

\author{
Rupayan Saha \\ Thesis submitted \\ to the Benjamin M. Statler College of Engineering and Mineral Resources \\ at West Virginia University \\ in partial fulfillment of the requirements for the degree of \\ Master of Science in \\ Civil and Environmental Engineering
}

Seung Ho Hong, Ph.D., Chair

Leslie C. Hopkinson, Ph.D.

Omar I. Abdul-Aziz, Ph.D.

Department of Civil and Environmental Engineering

Morgantown, West Virginia

2017

Keywords: Maximum scour depth prediction, Physical model, Bridge scour Copyright 2017, Rupayan Saha 


\section{ABSTRACT \\ Prediction of Maximum Scour Depth Using Scaled Down Bridge Model in a \\ Laboratory}

\section{Rupayan Saha}

Recently, United States faced catastrophic flooding in West Virginia, Texas, Louisiana, Oklahoma, and Arkansas, and the flooding resulted in several bridge failures. Among them, Bridge scour is one of the main causes of many bridge failures, and leads to financial losses as well as loss of life. Since 1960, a lot of scour research has been completed and several estimation methods were already in the hand of hydraulic engineers. However, scouring is still a challenging topic. Currently, the issues of scour are once again rising because the occurrence of extreme weather events are expected to increase in frequency. Furthermore, current practice of scour estimation shows over-prediction and sometimes, under-prediction. One possible reason is adding separate estimates of contraction and local scour when in fact these processes occur simultaneously. Another possible reason is that current scour equations are based on experiments using free-surface flow in idealized-rectangular flumes even though extreme flood event can cause bridge overtopping flow in combination with submerged orifice flow and the resulting scouring depth is site-specific. In this study, experiments were carried out by professor Hong at the hydraulics laboratory in the School of Civil and Environmental Engineering at the Georgia Institute of Technology in a compound shape channel using 1:60 bridge model of the Towaliga River Bridge at Macon, Georgia including river bathymetry in different flow conditions (free, submerged orifice and overtopping flow). Finding a solution regarding maximum scour depth calculation in clear water scour condition using required analysis of experimental results is contributed by myself. Based on the findings from laboratory experiments coupled with widely used empirical scour estimation methods, such as Colorado State University (CSU) pier scour equation, MelvilleSheppard equation and Ambient pier scour method, a comprehensive way of predicting maximum scour depth is suggested which overcomes problem regarding separate estimation of different scour depths. During the analysis, the effect of flow contraction on local scour was evaluated, and the result confirmed the necessity of single scour depth prediction method rather than separate estimation of different scour depths. In addition, an area-average contraction scour depth prediction method using ambient bed elevation around the local scour was also suggested and analyzed by measured flow contraction ratio. Also, the effect of vertical flow contraction and the effect of existence of a pier bent (located close to the abutment) on the maximum scour depth was investigated. The results show that in pressure flow, a combination of lateral and vertical contraction boosted the maximum scour depth. Results from the existence of the pier bent show that the location of maximum scour depth is unbiased on the presence of the pier bent but the amount of maximum scour depth is relatively higher due to the discharge redistribution when the pier bent is absence rather than its presence. 


\section{ACKNOWLEDGEMENTS}

This thesis could not be completed without the assistance, understanding and counselling of several people throughout the research work. I would like to express my sincere gratitude to my supervisor, Dr. Seung Ho Hong, for his continuous guidance, support and encouragement during my research. I appreciate the wisdom and confidence that he has imparted to me during our association.

I would also like to thank Dr. Hopkinson and Dr. Abdul-Aziz for serving as committee members. The work presented here was conducted at Hydraulics Laboratory of Georgia Institute of Technology and could have only been achieved through the collaborative effort of many individuals. Moreover, I have received support from the Department of Civil \& Environmental Engineering of West Virginia University with the office and computer facilities. I would like to express my appreciation to all of them.

I would like to recognize the support and help received from all of my colleagues and friends. They always refuel me with courage and inspiration to overcome any hardship encountered during this research period.

I am greatly indebted to my parents for their love and support. Without their many years of encouragement and support, I may never have reached where I am today.

Finally, I thank God for granting me success in all my endeavors. 


\section{Table of Contents}

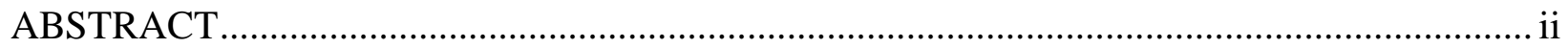

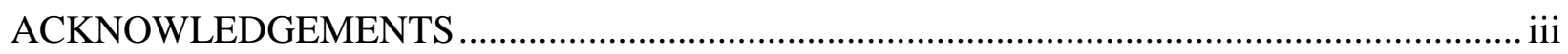

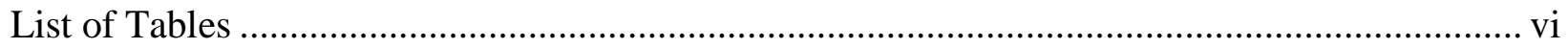

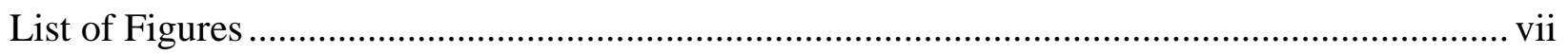

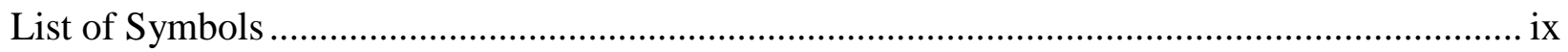

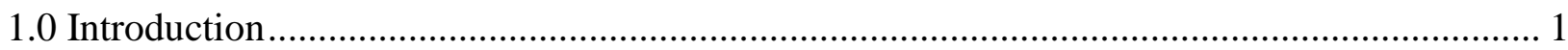

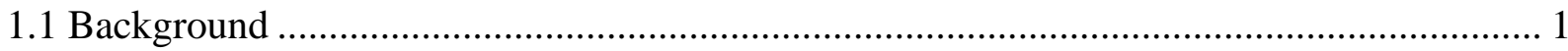

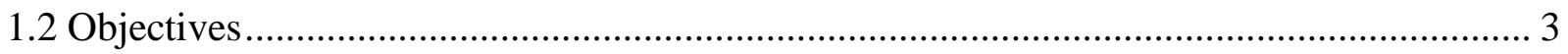

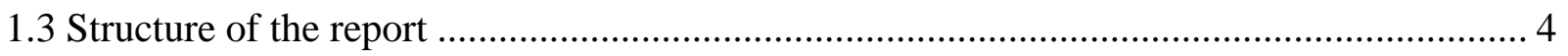

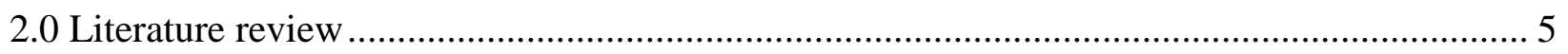

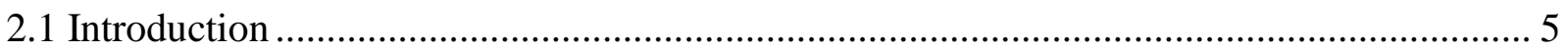

2.2 Types of scour

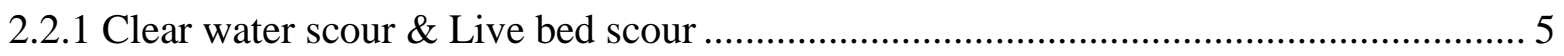

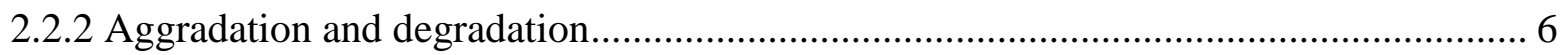

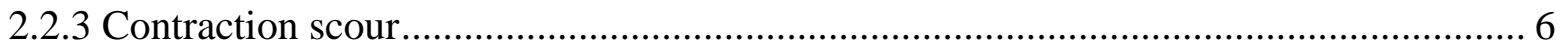

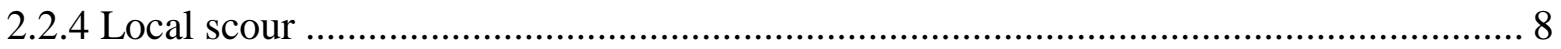

2.3 Pressure flow (Overtopping and Submerged orifice flow) ................................................. 9

2.4 Interaction between contraction scour and local scour .................................................. 11

2.5 Problems of laboratory and numerical models regarding scour depth calculation ............. 13

2.6 Predicted equations for local scour depth ................................................................... 15

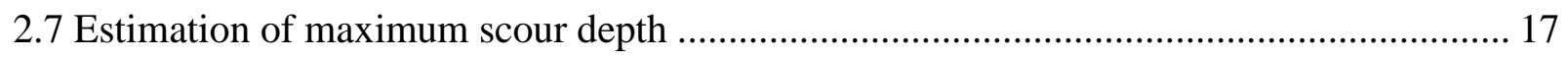

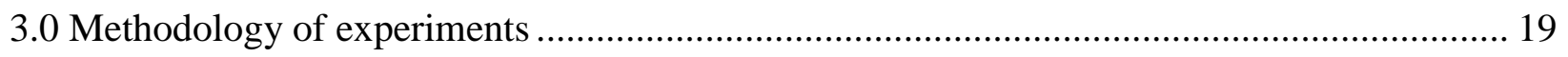

3.1 Experimental equipment …………………………............................................ 20

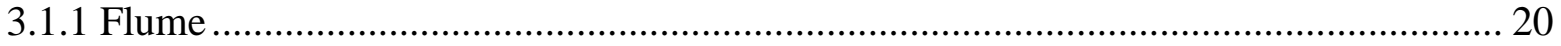




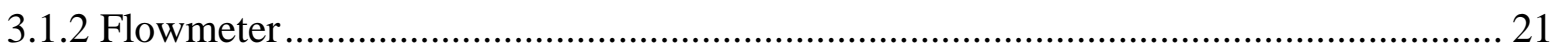

3.1.3 Acoustic Doppler Velocimeter (ADV) .................................................................... 22

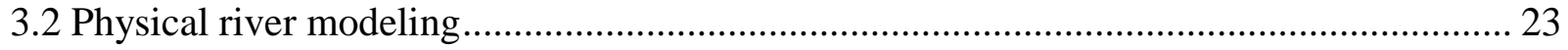

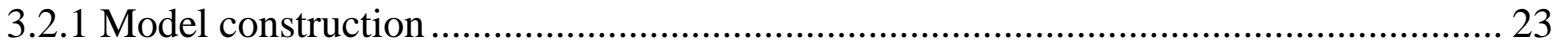

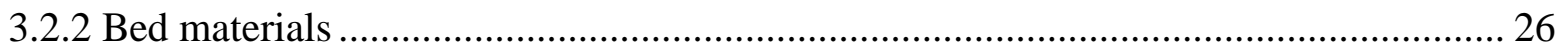

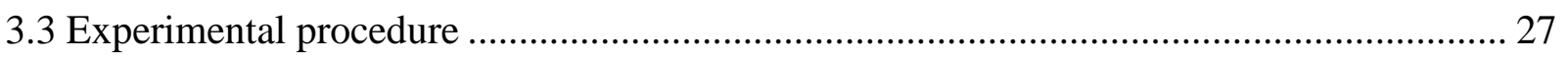

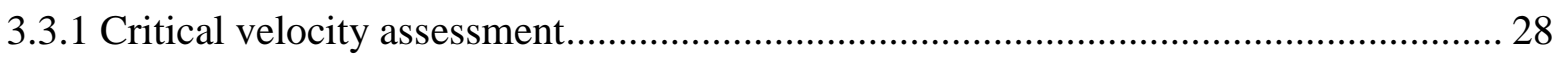

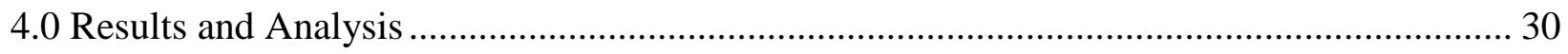

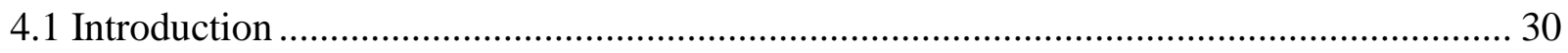

4.2 Experimental program and velocity measurements .......................................................... 30

4.3 Verification of physical laboratory modeling ………………............................................ 34

4.4 Location and measurement of the maximum scour depths ................................................. 35

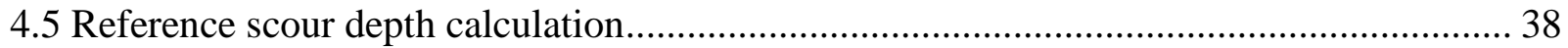

4.6 Prediction of maximum scour depth ………………....................................................... 39

4.7 Prediction of contraction effect on local scour.................................................................. 47

4.8 Area average contraction scour depth prediction .............................................................. 48

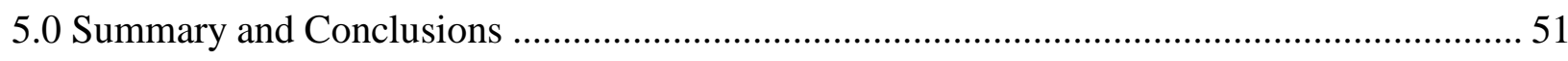

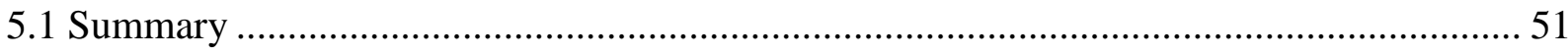

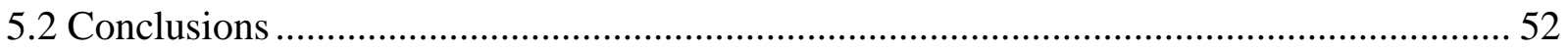

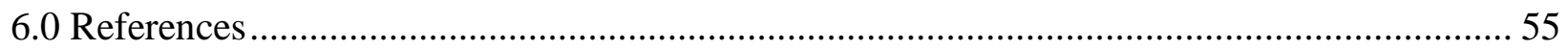

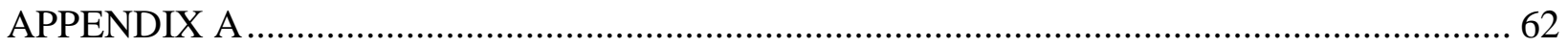

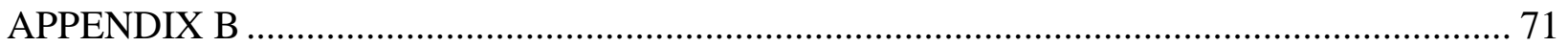




\section{List of Tables}

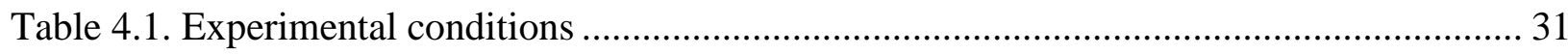

Table 4.2 Summary of maximum scour depth measured location and calculation .................... 37

Table 4.3. Summary of pier scour calculation using HEC-18 and M/S equations ..................... 39

Table 4.4. Summary of experimental results to calculate maximum scour depth .................... 50 


\section{List of Figures}

Figure 1.1. Ellsworth Barranca Bridge experiencing problem due to scour in Ventura County, California (California Department of Transportation) .................................................................... 2

Figure 1.2. Scour around bridge piers on the Tinau River, Nepal (Shrestha, 2015)....................... 2

Figure 3.1. Laboratory model of Towaliga River bridge ........................................................... 19

Figure 3.2. Location and view of Towaliga River Bridge ......................................................... 20

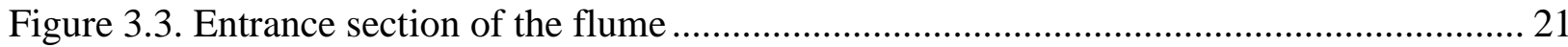

Figure 3.4. Tailgate of the flume to adjust the flow depth downstream ..................................... 21

Figure 3.5. Plan view of flume for model construction ............................................................ 25

Figure 3.6. Geometry of compound channel for (a) plan view; (b) cross section view at bridge

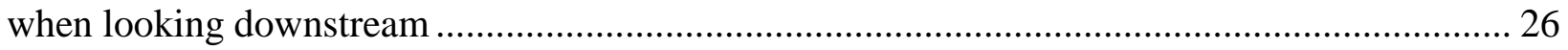

Figure 3.7. Sediment size distribution of the bed material for this study ..................................... 27

Figure 4.1. Plan view of velocity measurement locations ........................................................... 32

Figure 4.2. Approach flow velocity distributions for run 1 when looking downstream................ 33

Figure 4.3. Velocity distributions at upstream face of bridge section for run 1 when looking

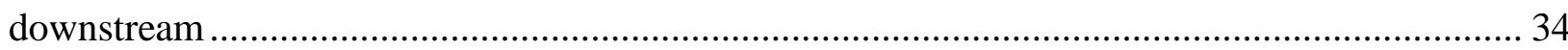

Figure 4.4. Comparison between measured laboratory data and observed field data.................... 35

Figure 4.5. Bridge cross-section comparison after scour for run 2 2........................................... 36

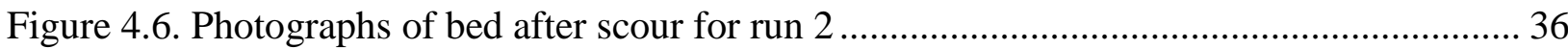

Figure 4.7. Schematic diagram of notations to calculate maximum scour depth ........................... 37

Figure 4.8. Schematic diagram for calculation of contraction scour using flow depth ................ 40

Figure 4.9. Normalized additional scour depth using CSU equation as a function of $q_{2} / q_{1} \ldots \ldots . . . .41$

Figure 4.10. Evaluation of vertical contraction effect using normalized additional scour depth as

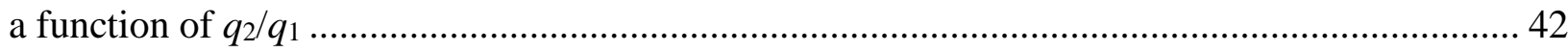

Figure 4.11. Normalized additional scour depth using $\mathrm{M} / \mathrm{S}$ equation as a function of $q_{2} / q_{1} \ldots \ldots . . .43$ 
Figure 4.12. Theoretical pier scour depth ratio using CSU and M/S equation in terms of flow

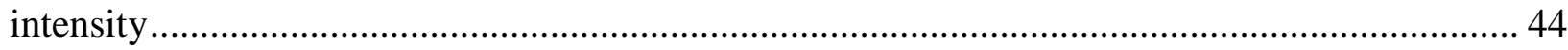

Figure 4.13. Adjusted ambient bed level after scouring of run 3 ........................................ 45

Figure 4.14. Normalized additional scour depth using ambient method as a function of $q_{2} / q_{1} \ldots . .46$

Figure 4.15. Normalized local scour depth due to contraction as a function of $q_{2} / q_{1} \ldots \ldots \ldots \ldots \ldots . . . . . .48$

Figure 4.16. Normalized area average contraction scour depth as a function of $q_{2} / q_{1} \ldots \ldots \ldots \ldots \ldots . . . . .49$ 


\section{List of Symbols}

$a=$ Pier width;

$a^{*}=$ Effective pier width;

$D_{\mathrm{m}}=$ Diameter of the smallest non-transportable particle in the bed material $\left(1.25 d_{50}\right)$;

$d_{50}=$ Median diameter of bed material;

$d *=$ Dimensionless grain diameter;

$d_{\mathrm{cs}}=$ Average contraction scour depth;

$d_{e s}=$ Maximum equilibrium scour depth;

$d_{p s}=$ Equilibrium pier scour depth;

$d_{c s u}=$ Calculated theoretical pier scour depth via CSU equation;

$d_{m s}=$ Calculated theoretical pier scour depth via M/S equation;

$d_{a m b}=$ Ambient pier scour depth;

$f_{1}=$ Flow-structure interactions factor;

$f_{2}=$ Flow-sediment interactions factor;

$f_{3}=$ Sediment-structure interactions factor;

$F=$ free flow;

$\mathrm{Fr}_{2}=$ Froude number at the upstream face of pier;

$h_{b}=$ Vertical bridge opening height before scour;

$K_{1}=$ Correction for pier nose shape;

$K_{2}=$ Correction for angle of attack of flow;

$K_{3}=$ Correction for bed condition;

$L_{r}=$ Length scale;

$O T=$ Overtopping;

$P=$ Submerged orifice flow;

$Q=$ Discharge through the bridge;

$q=$ Discharge per unit width;

$R=$ Hydraulic radius;

$S G=$ Specific gravity;

$t=$ Thickness of the separation zone at the location above maximum scour;

$V_{1}=$ Approach flow velocity; 
$V_{l e}=$ Average upstream velocity within the area from which all streamlines go under the bridge deck;

$V_{2}=$ Mean velocity of flow directly upstream of the pier;

$V_{b}=$ Average velocity of the flow through the bridge opening before scour occurs;

$V_{c}=$ Critical velocity;

$w=$ Depth of weir flow when flow overtops a bridge deck;

$W_{1}=$ Width of the approach section;

$W_{2}=$ Width of the contracted section;

$X=$ Distance from upstream face of bridge to maximum scour depth location;

$Y_{0}=$ Average depth of flow in the contracted section prior to contraction scour;

$Y_{1}=$ Average flow depth in the approach section;

$Y_{l e}=$ Flow depth below the stagnation point upstream, below which all streamlines go under the bridge superstructure;

$Y_{2}=$ Flow depth directly upstream of the pier;

$Y_{m}=$ Measured flow depth at the location of maximum scour depth;

$u *=$ Shear velocity $=\left(\tau_{0} / \rho\right)^{1 / 2} ;$

$u *_{c}=$ Critical value of shear velocity;

$\tau_{0}=$ Mean boundary shear stress;

$\tau *_{c}=$ Shields parameter;

$\rho=$ Fluid density;

$k_{s}=$ Equivalent sand-grain roughness height;

$\gamma=$ Specific weight of fluid;

$\gamma_{s}=$ Specific weight of sediment. 


\subsection{Introduction}

\subsection{Background}

Scour is the removal of bed material from the river bed and banks due to the complex flow pattern by the combination of fluvial and geomorphic process. Typically, bridge scour refers to the removal of bed materials such as sand and rocks through the bridge opening. When a bridge is constructed on a river, the flow pattern around the bridge will be significantly different because the unique flow field will be developed locally around the bridge pier and abutment. Furthermore, area contraction through the bridge opening by existence of embankment/abutments at both and/or one side of the river will result in higher flow velocity due to the acceleration. This unique flow field with the higher velocity can seriously damage the bridge foundation by decreasing the embedded depth of the foundation. Thus, if the depth of the foundation is not deep enough, the chance of bridge failure will become higher.

Sometimes, bridge can be failed because of several reasons, such as earthquake, flooding, and etc. Among them, bridge scour has been identified with the most common cause of bridge failures in the United States (Kattell and Eriksson 1998). For example, about $60 \%$ bridge failures of total bridge collapse in United States since 1950 were related to the scour of bridge foundations (Shirhole and Holt, 1991). The Colorado Department of Transportation (CDOT) estimated a minimum of 30 state highway bridges were destroyed and 20 were seriously damaged by flood in the year of 2013 (Novey, 2013). In Nepal, due to the degradation of the bed materials during 2014 flooding, the foundation of highway bridge over the Tinau River was exposed (Shrestha, 2015). As explained in the above examples, it is justified to say that bridge scour is one of the main bridge safety problems all over the world.

In the economic point of view, it was reported that, in 1993 alone, more than 2,500 bridges were destroyed or severely damaged due to scour caused by severe flooding, which reflects around $\$ 178$ million of the total repair costs (Arneson et al., 2012). Additionally, in 1994, over 1,000 bridges were closed in Georgia during flooding, and the financial cost toward to the Georgia Department of Transportation (GDOT) was estimated to be around \$130 million (Stamey, 1996). There is a substantial amount of direct cost associated with repair and replacement of river bridges damaged by flood. However, the indirect cost to local businesses and industries due to disruption 
in commercial activities was estimated five times more than for the direct repair cost (Hallegatte, 2015). Figures $1.1 \& 1.2$ give a clear illustration of the scour problem around bridge piers and its consequences. Figure 1.1 displays Ellsworth Barranca Bridge which has been classified as "scour critical" by California Department of Transportation in 2011. Figure 1.2 shows main highway bridge over the Tinau River in Nepal which has deeper scour around the bridge pier and resulting foundation exposure.

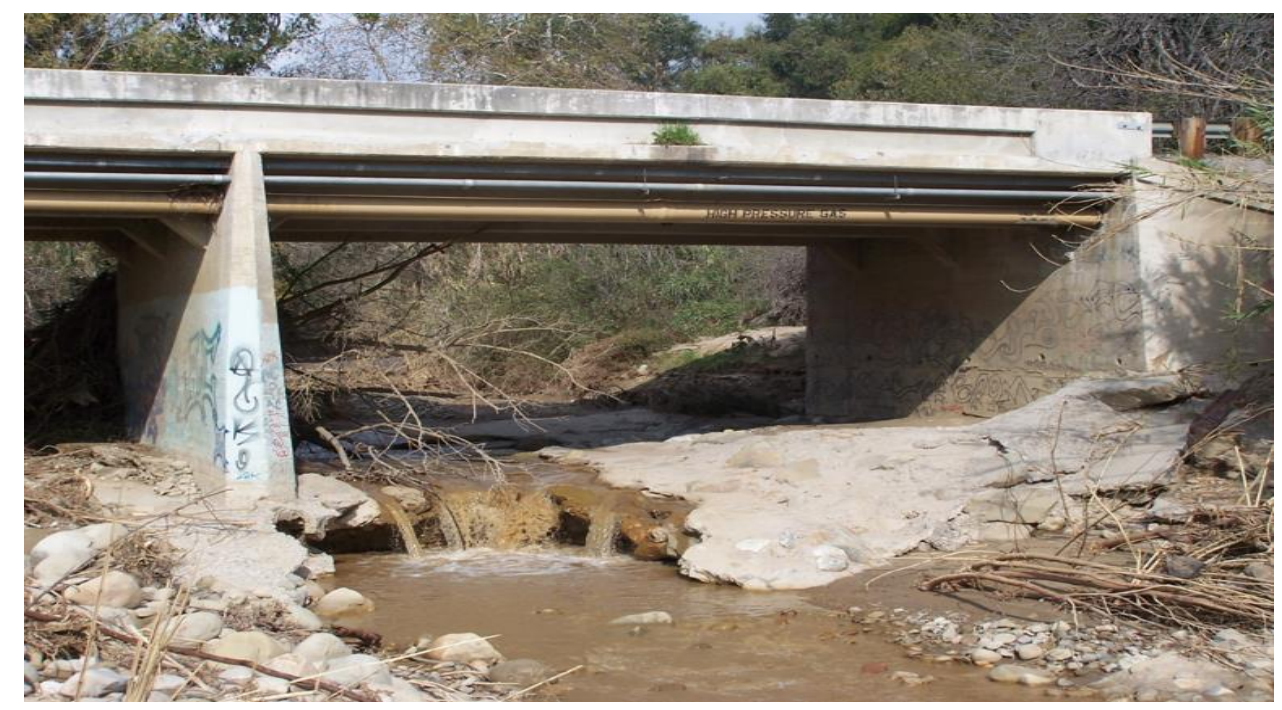

Figure 1.1. Elsworth Barranca Bridge experiencing problem due to scour in Ventura County, California (California Department of Transportation)

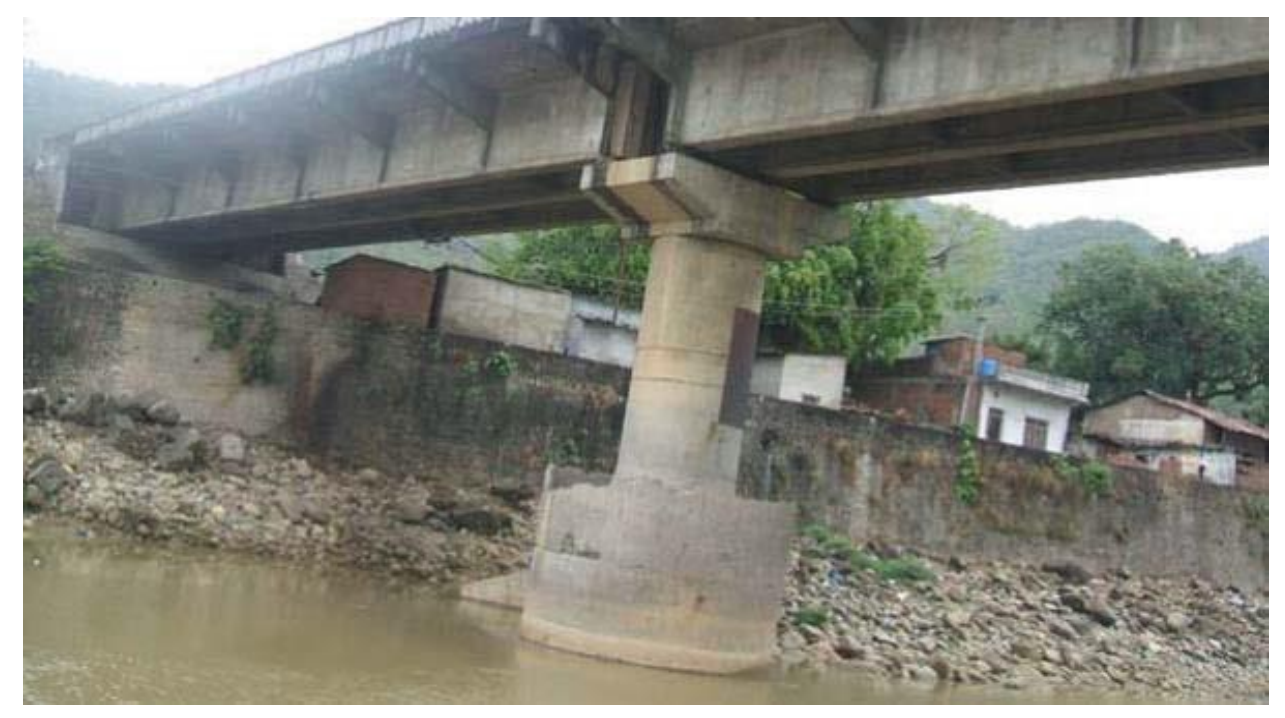

Figure 1.2. Scour around bridge piers on the Tinau River, Nepal (Shrestha, 2015) 
Even though bridge scour is one of the main cause of bridge failures, there are not enough evidence to acknowledge any equations that can be used to predict bridge scour depth precisely. Thus, engineers applied large safety factor for bridge design which increases construction cost because overestimation of the scour depth results in deeper foundation, and leads to an uneconomical design of bridges. However, without applying large safety factor to compensate the lack of accurate method, bridge design would result in shallow foundation and provide more chance to foundation exposure during the flooding which is definitely dangerous for bridge safety.

One of the possible reasons of lacking accurate scour prediction method is that many of the scour predictor equations were derived from simplified laboratory studies. The complex flow motion around the bridge obstruction presented by the bridge foundation and site-specific river geometries cannot be reproduced in a simplified-idealized laboratory setting such as in rectangular flume as in the previous research. Moreover, there are limited number of field data that can be used for validation of laboratory results. Generally, maximum scour depth reached at the peak flooding event. Scour hole became larger on the rising stage of water level and reached maximum at the peak of the flood and partially was filled back on the falling stage. So it is hard to measure the maximum scour depth because of the safety of measuring crews during peak flooding.

In addition to the un-realistic laboratory setting, another possible reason for the inaccurate prediction of scour depth is that current Federal Highway Administration (FHWA) guidelines assume that contraction and local scour are independent processes. So they recommend separate calculation of contraction and local scour and then, summation of the two to estimate total scour depth. However, contraction and local scour is not independent process. Research by Hong (2005) and Hong and Abid (2016) showed the evidence of reduced contraction scour depth due to interaction with the local pier scour. As a matter of fact, very few laboratory studies have been conducted to find a way to predict maximum scour depth by one equation which is the main focus of this thesis.

\subsection{Objectives}

The laboratory experiments were conducted in Georgia Institute of Technology, Atlanta, using a 1:60 scale down hydraulic model of the Towaliga River Bridge at Macon, Georgia 
including full rive bathymetry by professor Hong. This research is an attempt to understand the following key points for improving estimation methods of maximum scour depth in three different flow types (Free, Submerged orifice, and Overtopping flow). Key problems that have been attempted to be solved through the current study of scour are as follows:

- To evaluate the effect of flow types on maximum scour depth in a clear water condition;

- To develop a method to find contraction effect on local scour in different flow types;

- To identify the difference between lateral and vertical contraction scour in a compound channel;

- To evaluate the change of area average contraction scour depth with flow contraction in compound channels;

- To investigate the effect of existence of a pier bent (located closed to the abutment) on the maximum scour depth;

- To develop a methodology that can be used to predict maximum scour depth in an improved way using previously established scour equations.

\subsection{Structure of the report}

Appropriate literature reviews of experimental studies on contraction scour, local scour around bridge pier, and interaction between contraction scour and local scour is presented in Chapter 2. The details of the Acoustic Doppler Velocimeter (ADV) system, experimental set-up and procedures, and river modeling in the lab are provided in the Chapter 3 . The experiments were carried out by Dr. Hong. My contribution was finding a solution to calculate maximum scour depth based on the experimental data analysis with proper investigation. The results and the analysis are presented in Chapter 4. Finally, conclusions and recommendations are presented in Chapter 5. 


\subsection{Literature review}

\subsection{Introduction}

Scour calculation is one of the essential fraction in bridge design procedure because scour is one of the main causes of bridge failure. It is caused by flowing water that removes the bed material around the bridge foundation. As scour developed, the bridge foundations are exposed and becoming unstable. Thus, accurate prediction of scour at the bridge foundation becomes the primary ground by engineers for the safety of bridge.

Using the available literatures, this chapter sums up description on different types of scour such as clear water and live bed scour, scour due to aggradation and degradation, contraction scour and local scour. This description includes mechanisms of scour and important factors in process of scour. Then, pressure flow is described because we are intended to investigate the effect of different flow types, free flow and pressure flow, on maximum scour depth. After that, interaction between contraction scour and local scour is presented, and problems regarding scour depth prediction are discussed. Later, empirical equations for theoretical pier scour depth calculation (CSU and Melville-Sheppard equations) are described because the theoretical pier scour calculation is used as reference scour depth for the maximum scour depth calculation. Finally, the necessity of having a unifying equation for maximum scour depth prediction around bridge piers is explained based on the existing literatures.

\subsection{Types of scour}

\subsubsection{Clear water scour \& Live bed scour}

According to Chabert et al. (1956), there are two types of scour that varies depending on the approach flow velocity. One of them is clear water scour, where sediments move from scour holes, but not replaced by the sediment of approach flow. The other is live bed scour, where the scour hole is continuously refilled with sediment by the approach flow. The deciding factor between clear water and live bed scour is the ratio of approach flow velocity $\left(V_{1}\right)$ to the critical velocity $\left(V_{c}\right)$, in which critical velocity $\left(V_{c}\right)$ is the flow velocity for initiation of motion for 
sediment. Calculation of critical flow velocity using a graphical Shields diagram will be described later in sub-chapter 3.3.1.

Clear water scour in the vicinity of the foundation structure starts with an initial period of rapid erosion and is followed by equilibrium. That is, in clear water scour, an equilibrium scour depth is reached when the flow can no longer remove particles from the scour hole. However, in live bed scour, as the bed materials transported from the upstream drops it into the scour hole continuously, there is a continuous process of adding and removing bed materials into the scour hole. Under live bed scour conditions, when the amount of sediment being removed from the hole and the amount entering is equal, equilibrium scour depth is reached.

\subsubsection{Aggradation and degradation}

Aggradation is the deposition of material being carried by the flowing water from the upstream whereas degradation is the lowering of the river bed because of the gradual and general removal of sediments from the riverbed. Long-term aggradation and degradation of a riverbed can be caused by human changes in the river or natural processes. Dams, reservoirs, change of land use or natural change of water elevation are some of the effective factors for aggradation and degradation (Kalantari, 2014).

\subsubsection{Contraction scour}

Contraction scour occurs throughout the contracted area induced by man-made structures and/or natural geometries. This scour involves the removal of material from the bed or banks across the channel width. The most common cause of the contraction scour is the encroachment of bridge embankments either into the main channel or into the flood plain. When the flow area becomes less due to the construction of bridge abutments/embankments, the velocity is increased and the corresponding shear stress on the contracted channel becomes higher. Thus, the bed sediment within the channel contraction is eroded. 
Contraction scour can occur either in clear water or live bed condition. Current analytical methods for computing clear water contraction scour is outlined in HEC-18 based on a sediment transport theory suggested by Laursen (1963). The equations are defined as follows:

$$
\begin{aligned}
& Y_{2}=\left[\frac{K_{u} Q^{2}}{D_{m}^{2 / 3} W_{2}^{2}}\right]^{3 / 7} \\
& d_{c s}=Y_{2}-Y_{0}
\end{aligned}
$$

where, $Y_{2}$ is the average equilibrium flow depth in the contracted section after the contraction scour, in $\mathrm{ft}$; $Q$ is the discharge through the bridge, in $\mathrm{ft}^{3} / \mathrm{s} ; D_{\mathrm{m}}$ is the diameter of the smallest nontransportable particle in the bed material $\left(1.25 d_{50}\right)$ in the contracted section, in $\mathrm{ft} ; d_{50}$ is the median diameter of bed material, in $\mathrm{ft}$; $W_{2}$ is the width of the contracted section less pier widths, in $\mathrm{ft}$; $d_{\mathrm{cs}}$ is the average scour depth in the contracted section, in $\mathrm{ft}$; $Y_{0}$ is the average depth of flow in the contracted section prior to contraction scour, in $\mathrm{ft}$; and $K_{\mathrm{u}}$ is a constant value of 0.0077 for English units.

The depth of live bed scour in a contracted section can be predicted by using a modified version of Laursen's equation (HEC-18), which is defined as:

$$
\begin{aligned}
& \frac{Y_{2}}{Y_{1}}=\left(\frac{Q_{2}}{Q_{1}}\right)^{\frac{6}{7}}\left(\frac{W_{1}}{W_{2}}\right)^{k_{1}} \\
& d_{c s}=Y_{2}-Y_{0}
\end{aligned}
$$

where, $Y_{1}$ is the average flow depth in the approach section, in $\mathrm{ft}$; $Q_{1}$ is the flow in the upstream transporting sediment, in $\mathrm{ft}^{3} / \mathrm{s} ; Q_{2}$ is the flow at the contracted section, in $\mathrm{ft}^{3} / \mathrm{s} ; W_{1}$ is the width of the approach section, in $\mathrm{ft} ; k_{1}$ is an exponent determined from the ratio of shear velocity in the upstream section to the fall velocity of bed material based on transportation mode of bed material. HEC-18 recommended that contraction scour must be computed separately for the main channel and the left and/or right floodplain areas using ( $2.1 \& 2.2)$ equations. 


\subsubsection{Local scour}

Changes in the flow pattern around hydraulic obstacles such as a pier and an abutment will result in a stronger erosive stress and the bed materials around the hydraulic obstacles can be removed from the streambed locally due to the higher erosive force, and this is called local scour.

Many researchers (Melville (1975); Ettema (1980); Qadar (1981); Chiew (1984); Davoren (1985); Hamill (1999); Melville and Coleman (2000); Richardson and Davis (2001); Sheppard (2004); Barbhuiya and Dey (2004); Khwairakpam et al. (2012)) in the past stated that the basic mechanism of local scour is a system of vortices developed around the base of bridge local structures such as a pier and an abutment. To understand the scour mechanism around a bridge pier, it is necessary to understand the flow field around a pier. As reported by Melville and Coleman (2000), the principal features of the flow field at a bridge pier are down-flow at upstream side of the pier, the horseshoe vortex at the base of the pier, the surface roller at upstream side of the pier and wake vortices downstream of the pier. This flow field is three-dimensional and unsteady due to the ongoing interactions between these turbulent flow structures (Ettema et al., 2011).

In open channel flow, the velocity profiles shows logarithmic distribution over the depth, such that maximum velocity occurs at the water surface and zero at channel bed. When the flow encounters the upstream face of the pier, flow velocity abruptly becomes to zero, this causes pressure to decrease in the downstream direction (Figliola and Beasley, 2011). A downward pressure gradient forms at the nose of pier, causing increased flow velocity in a downward motion (Dey et al., 1995). The down-flow, once initiated, induces scouring action at the upstream base of the pier (Chiew, 1984). Then, the down-flow curls up and wraps around the pier, initiating formation of the horseshoe vortex as explained in Ozturk et al. (2008). As described earlier, other turbulent structures around the pier also effect on scour. A bow wave can be generated when the upward flow forms a circulation near the free surface that causes the flow depth to increase in front of a bridge pier (Simpson, 2001). It is noted that a bow wave does not dominate the local pier scour mechanism unless the flow depth is too shallow and about equal to the sum of the diameters of a horseshoe vortex and a bow wave (Lee, 2006). Wake vortices are developed due to flow separation on the bridge pier. Strong wake vortices may develop a large scour hole downstream from the piers. The behavior of wake vortices mimics a tornado, removing sediment from the channel bed 
in an upward motion. The volume of sediment transported by wake vortices is smaller than the volume of sediment transported by the horseshoe vortex system (Williams, 2014). Vortices (Horseshoe and Wake) contribute to the removal of bed material and the deepening of the scour hole and the depth of the scour hole continues to increase until it is reached to equilibrium (Shrestha, 2015).

\subsection{Pressure flow (Overtopping and Submerged orifice flow)}

Throughout the extreme hydrologic events, pressure flow might occurs in the bridge. One of the objectives of this study is to evaluate the effect of flow types on maximum scour depth in clear water condition. Thus, previous studies on the topic of pressure flow condition are summarized in this section.

During the extreme flood events, pressure flow occurs when a bridge deck is insufficiently high such that the bridge superstructure becomes a lateral barrier to the flow, causing the flow vertically contract as it passes under the deck. Depending on the amount of discharge and bridge deck elevation, some amount of water can be overtopped of bridge deck. In the pressure flow, because of the vertical flow contraction in addition to the exiting lateral flow contraction, the scour depth become larger.

Investigations of bridge scour in pressure flow have been reported by Arneson and Abt (1998), Umbrell et al. (1998) and Lyn (2008). Arneson and Abt (1998) conducted a series of flume tests and proposed the following regression equation,

$$
\frac{d_{e s}}{Y_{1}}=-0.58+1.27\left(\frac{Y_{1}}{h_{b}}\right)+4.44\left(\frac{h_{b}}{Y_{1}}\right)+0.19\left(\frac{V_{b}}{V_{c}}\right)
$$

where, $d_{e s}=$ maximum equilibrium scour depth, $Y_{1}=$ depth of approach flow before scour, $h_{b}=$ vertical bridge opening height before scour, $V_{b}=$ average velocity of the flow through the bridge opening before scour occurs, and $V_{c}=$ critical velocity of the bed material in the bridge opening defined by,

$$
V_{c}=1.52 \sqrt{g(s-1) d_{50}}\left(\frac{Y_{1}}{d_{50}}\right)^{1 / 6}
$$


where, $g=$ gravitational acceleration, $\mathrm{s}=$ specific gravity of sediment, and $d_{50}=$ median diameter of bed materials. Meanwhile, Umbrell et al. (1998) also conducted a series of flume tests at the FHWA's Hydraulics Laboratory. Applying conservation of mass and assuming that the velocity under a bridge at scour equilibrium is equal to the critical velocity of the upstream flow, they presented the following equation,

$$
\frac{d_{e s}+h_{b}}{Y_{1}}=\frac{V_{1}}{V_{c}}\left(1-\frac{w}{Y_{1}}\right)
$$

where, $V_{1}=$ approach flow velocity that is less than or equal to the critical velocity $V_{c}$, and $w=$ depth of weir flow when flow overtops a bridge deck and $w=0$ for partially submerged flow. Using flume experimental data, Umbrell et al. (1998) modified equation as follows,

$$
\frac{d_{e s}+h_{b}}{Y_{1}}=1.102\left\lceil\left.\frac{V_{1}}{V_{c}}\left(1-\frac{w}{Y_{1}}\right)\right|^{0.603}\right.
$$

where the critical velocity is estimated by equation (2.4) except that the coefficient, 1.52, is replaced by 1.58 . Another study was reported by Lyn (2008), who reanalyzed Arneson's (1998) and Umbrell's (1998) data sets and proposed the following power law,

$$
\frac{d_{e s}}{Y_{1}}=\min \left[0.21\left(\frac{V_{b}}{V_{c}}\right)^{2.95}, 0.6\right]
$$

where, $V_{b}$ and $V_{c}$ are the same as in equation (2.4). Lyn's (2008) equation is an empirical model, but he identified the spurious regression of equation (2.4) and the low quality of Umbrell's (1998) data set. In another experiments by Hahn and Lyn (2010), they observed that the maximum scour occurred at a location downstream of the vertical contraction section.

Shen et al. (2012) collected data from a recent pressure flow scour study conducted at Turner-Fairbank Highway Research Center (TFHRC), McLean, VA. Two uniform sands were used in the experiments to test the effect of sediment size on scour morphology. Furthermore, to find the effect of different number of girders in bridge deck, two different deck models was constructed in their experiments. Each test lasted till equilibrium was attained. Using the experimental data and Computational Fluid Dynamics (CFD), a formula was developed to calculate pressure flow scour depth under various bridge inundation conditions. The maximum scour depth was evaluated by using contraction scour equations combined with a correlation of 
separation zone thickness under the inundated bridge. Considering clear water condition, an equation for vertical contraction scour depth was obtained,

$$
h_{b}+d_{e s}=\left(\frac{V_{1 e} Y_{1 e}}{K_{U} d_{50}^{1 / 3}}\right)^{\frac{6}{7}}+t
$$

where, $h_{b}=$ the clearance depth of the bridge before scour, $d_{e s}=$ the maximum equilibrium scour depth measured from the non-scoured stream bed, $V_{l e}=$ the average upstream velocity within the area from which all streamlines go under the bridge deck, $Y_{l e}=$ the depth below the stagnation point upstream, below which all streamlines go under the bridge superstructure, $K_{U}=11.17$ for English units, $d_{50}=$ sediment size, $t=$ the thickness of the separation zone at the location above maximum scour. This equation was also included in HEC-18 for prediction of pressure flow scour underneath an inundated deck during an extreme flood event. Even though several researches have been conducted for the scour in pressure flow as explained above, all of the studies were conducted in a rectangular flume without lateral contraction. Thus, the current equations are only valid for the case of the pressure flow without lateral flow contraction which is un-realistic compared to the actual field.

\subsection{Interaction between contraction scour and local scour}

Contraction scour is the consequence of flow acceleration due to contraction in the flow area, while local scour is caused by local vortex induced by the downward flow along the upstream nose of the obstruction and their interaction with sediment materials around the base of the obstruction. When the bridges are constructed in the river, those two flow pattern tends to occur concurrently, which made local scour and contraction scour time dependent. The interaction of bridge contraction scour and pier scour was studied by Hong (2005) using a 1:45 scaled hydraulic model of the Ocmulgee River bridge at Macon, Georgia. Two different circumstances were considered in the laboratory to investigate the interaction. Those were "with the bridge piers" and "without the bridge piers". Hong (2005) found that contraction scour depth became less "with the

bridge piers" compared to the "without the bridge piers" because of the interaction between flow contraction and existence of local piers. Discharge redistribution across the bridge cross section as scour developed over time can be the reason for this behavior. Because pier scour developed much 
faster than the contraction scour, rapid development of pier scour changes the discharge distribution across the bridge cross section before the contraction scour has fully developed.

Nyarko and Ettema (2011) also conducted a series of flume experiments to evaluate the interactions between pier scour and abutment scour. They varied the location of pier from a spillthrough and a wing-wall abutments, and investigate the proximity of a pier to the abutment scour depth. Their results reported that when a pier was located within the immediate vicinity of an abutment (within approximately three times floodplain flow depth from the toe of an abutment), abutment scour dominated at the maximum scour depth. However, they pointed out when a pier was at the toe of a spill-through abutment on an erodible floodplain, pier presence reduced abutment scour depth by approximately $10-20 \%$ because the pier is acted as retaining riprap stone. But around the wing-wall abutment, pier presence increased abutment scour depth by less than $10 \%$ due to additional turbulence generated by flow around the pier.

In the field studies, Holnbeck et al. (1993) compared measured contraction and abutment scour at U.S. 87 over Razor Creek in Montana with calculated scour depth. They used the computer model WSPRO for the calculation of hydraulic variables and applied the results to Laursen's livedbed equation to compute contraction scour. For the abutment scour and pier scour through the bridge, the Froehlich live bed equation and Colorado State University (CSU) equation were used respectively. Then, with the results calculated from separate equations for each scour depth (pier, abutment and contraction scour depth), total scour depth was decided by summation of the three individual scour depths. The results showed that calculated total scour depths were larger than the observed scour depth in the field, and indicated that linear summation of local scour and contraction scour resulted in over-predicted total scour depth because of interaction among the each scour type.

Another field study can be found in Lee and Hedgecock (2007). The U.S. Geological Survey (USGS), in cooperation with the Alabama Department of Transportation, observed clear water contraction scour at 25 bridge sites in the Black Prairie Belt of the Coastal Plain of Alabama (Lee and Hedgecock, 2007). Theoretical clear water contraction scour depths were computed for each bridge and compared with observed scour. This comparison showed that theoretical scour depths, in general, exceeded the observed scour depths by about 475 percent. 
An evaluation of existing abutment scour formulas by Strum et al. (2011) concluded that independent scour processes cannot be assumed because the severe contraction in flow area through the bridge opening tends to cause scour processes to act concurrently, and it is difficult to separate the contraction and local scour processes. However, HEC-18 still suggested that local and contraction scour processes are independent and summed for total scour depth. Thus, as explained in the objective of this study, a universal way to predict maximum scour depth using one equation need to be developed rather than using separate equations for different types of scour to calculate the maximum scour depth.

\subsection{Problems of laboratory and numerical models regarding scour depth calculation}

Predicting bridge scour using available information is very important in preventing catastrophic failure of bridges and possible loss of life. Thus, a lot of research have been conducting to suggest better scour prediction methods and they were available in literatures. Though most empirical equations for predicting bridge scour depth have been demonstrated under certain laboratory or field condition, they may not be suitable where laboratory or field conditions are changed (Deng and Cai, 2010). Also, it is difficult to mimic the field conditions in laboratory due to the complex interaction between the flow, sediment and riverbed.

However, Hong and Sturm (2006) and Hong and Abid (2015) showed that the complex field geometries can be reproduced in the laboratory based on scaling techniques. In their experiments, they matched up the Froude number between laboratory and field, and carefully chose the sediment size to simulate the experiment in clear water condition. They successfully reproduced field velocity distributions of historic flood events in the laboratory. Furthermore, they found measured field live bed contraction scour depth can be reproduced in the maximum clear water condition in the laboratory within $5 \%$ error limit.

In another study by Ghazvinei et al. (2015) on contraction scour at protruding bridge abutments, maximum contraction scour depth and their location were predicted by using parametric analysis (PA). Parametric analysis is a technique to examine the model behavior systematically using various inputs variables. Statistical and graphical tests indicated that the PA method gives reliable prediction of the contraction scour depth around a protruded abutment in a 
compound channel. The study found that the depth and location of the maximum contraction scour vary for different ratios of abutment length to floodplain width. This ratio was defined as abutment protrusion ratio. But this model technique focused on the relationship between measured equilibrium contraction scour depth and only input variables rather than considering interactions between different variables and parameters.

While development of empirical equations for scour prediction is ongoing, another form of scour prediction is being investigated as well. The use of artificial neural networks (ANN) and computational fluid dynamics (CFD) has been initiated for the purposes of flow simulation and scour prediction. In a numerical study on experimental data, Najafzadeh et al. (2015) investigated scour depth in long contractions of rectangular channels using the Adaptive Neuro-Fuzzy Inference System (ANFIS) and Support Vector Machines (SVM). For modeling of ANFIS and SVM, the input parameters that affect the scour phenomena are average flow velocity, critical threshold velocity of sediment movement, flow depth, median particle diameter, geometric standard deviation, un-contracted and contracted channel widths. The performances of the developed models are compared with traditional equations given by Laursen (1963), Komura (1966), Gill (1981), and Lim (1993) developed with long contraction and rectangular shape channel assumption. The results showed that the developed ANFIS and SVM model successfully predict the scour depth. However, actual channel shape is not rectangular and there is no clear definition of long and short contraction. Thus, application of ANFIS and SVM to the actual river geometry is doubtable.

The mechanism of flow around a pier structure is so complicated that it is difficult to establish a general empirical model to provide accurate estimation for scour. But the advantage of laboratory studies of bridge scour is that they help to understand the effect of different variables and parameters associated with scour and hence improve the scour prediction equations, but also help to develop alternative or improved approach of scour countermeasures. On the other hand, in order to verify the accuracy of the developed numerical models, most numerical models were developed along with laboratory models and their results were compared with each other. So anyhow laboratory models are essential to establish an equation of maximum scour depth and in our study, we conducted physical modeling in similar approach made by Hong and Abid (2015) using the Froude number similarity between laboratory and field. 


\subsection{Predicted equations for local scour depth}

Empirical equations that were developed on bridge pier scour attempted to predict equilibrium scour depth using the various variables. They have been mainly developed for systems under clear water conditions with non-cohesive sediments (Guo, 2012). The majority of variables which affect scour depth can be categorized into five groups (Chiew, 1984):

- Fluid properties: density, $\rho$; kinematic viscosity, $v$; and temperature, which is not a primary concern in the lab but rather in the field, where it cannot be controlled.

- Time: Scour is a temporal process.

- Flow properties: water depth, $Y$; energy slope; shear stress in uniform flow; angle of attack, $\theta$; mean flow velocity, $V$; and critical velocity of bed material, $V_{c}$.

- Pier characteristics: pier diameter, $a$; shape; surface condition; pier orientation; and debris accumulation.

- Sediment characteristics: sediment density, $\rho_{s}$; median sediment size or diameter, $d_{50}$; uniformity of particle size distribution, $\sigma_{g}$; cohesiveness; shape factor; angle of repose; and fall velocity.

The most commonly used equation for prediction of equilibrium pier scour depth is the HEC-18 equation. The HEC-18 equation, also known as the CSU equation, can be used both for clear water and live bed conditions (Deng and Cai, 2010). The CSU equation was initially developed from a plot of laboratory data set measured by several researchers including Chabert and Engeldinger (1956), and Shen et al. (1966). After the initial development, HEC-18 equation has been progressively modified over the years and is currently recommended by FHWA for estimating equilibrium scour depths at simple piers (Arneson et al. 2012) as follow:

$$
\frac{d_{p s}}{Y_{2}}=2 K_{1} K_{2} K_{3}\left(\frac{a}{Y_{2}}\right)^{0.65} F r_{2}^{0.43}
$$

where, $K_{1}=$ Correction for pier nose shape $\left(K_{1}=1\right.$ for circular piers $)$,

$K_{2}=$ Correction for angle of attack of flow $\left(K_{2}=1\right.$ for direct approach flow $\left.\theta=0^{\circ}\right)$,

$K_{3}=$ Correction for bed condition $\left(K_{3}=1.1\right.$ for clear water scour $)$,

$$
F \mathrm{r}_{2}=\text { Froude number }=V_{2} /\left(g y_{2}\right)^{0.5},
$$


$a=$ Pier width,

$d_{p s}=$ Equilibrium scour depth,

$Y_{2}=$ Flow depth directly upstream of the pier,

$V_{2}=$ Mean velocity of flow directly upstream of the pier,

$g=$ Acceleration of gravity

It rarely under-predicts scour depth but often generated an unnecessarily high prediction (Guo, 2012). Mueller (1996) found that this equation was useful in design purposes because observed scour depth by USGS was typically less than calculated scour depth using CSU equation. But due to over prediction, the construction cost becomes higher. In another study, Johnson (1995) concluded that predicted scour depths were substantially larger than observed scour in the field for high Froude numbers $\left(F r_{2}>0.8\right)$ but worked well in very low Froude numbers.

Another commonly used pier scour prediction method is the Melville-Sheppard or M/S equation (2011). M/S equation (2011) is an improvement of previous findings such that it follows the same parameter approach of the Melville (1997) and updates the method proposed by Sheppard and Miller (2006) including particle size. M/S equation combines pier geometry, shape, and angle of attack as in one variable (effective pier width, $a^{*}$ ), and distinguishes between clear water and live bed flow conditions. The equation is as follows:

$$
\frac{d_{p s}}{a^{*}}=2.5 f_{1} f_{2} f_{3}
$$

where, $f_{1}$ is flow-structure interactions, $f_{2}$ is for flow-sediment interactions, and $f_{3}$ is for sedimentstructure interactions. Here,

$$
\begin{aligned}
& f_{1}=\tanh \left[\left(\frac{Y_{2}}{a^{*}}\right)^{0.4}\right] \\
& f_{2}=\left\{1-1.2\left[\ln \left(\frac{V_{2}}{V_{c}}\right)\right]^{2}\right\} \\
& f_{3}=\left[\frac{\left(\frac{a^{*}}{d_{50}}\right)^{1.13}}{10.6+0.4\left(\frac{a^{*}}{d_{50}}\right)^{1.33}}\right]
\end{aligned}
$$


where, $a^{*}=$ Effective pier width, $V_{2}=$ Mean velocity of flow directly upstream of the pier, $V_{c}=$ Critical velocity for movement of $d_{50}, d_{50}=$ Median particle size of bed material.

Although the HEC-18 equation provides good results for most applications, the M/S equation should be considered as an alternative, particularly for wide piers $\left(Y_{2} / a<0.2\right)$ in shallow flows with fine bed material. Because in addition to the similar variables in HEC-18 equation, additional variables such as bed sediment size $\left(d_{50}\right)$, effective pier width $\left(a^{*}\right)$ and the flow intensity were considered in $\mathrm{M} / \mathrm{S}$ equation for the calculation of pier scour depth. So in comparison of HEC18 and M/S equation takes better account of the flow-pier, the flow-sediment and the pier-sediment interactions (Tejada, 2013). While the majority of provisions of the HEC-18 or M/S equation for hydraulic design of bridge piers, recent developments in scour research have indicated the need for an updated equation (Ettema et al., 2011). Several investigations have served to compare these equations with experimental results and/or field measurements, and determine which of them, if any, offer an accurate prediction of bridge scour. The HEC-18 equation appeared to rarely offer a low estimate of scour depth, but often generated an unnecessarily high prediction. For serviceability concerns, conservative estimates are clearly more desirable than low estimates; however, such estimation will yield an uneconomical design (Guo, 2012). As discussed, overestimation occurs as a result of various phenomena. One of these, which is a primary weakness of currently used equilibrium scour depth estimation methods, lies in their failure to include or articulate some pertinent influences (Ettema et al., 2011). Both equations were derived from experimental data of laboratory on idealized rectangular channel with no contraction. But in real field, most of the channels are curvilinear and compound in shape, and natural or man-made contractions present in it. So influence of these relevant parameters will need to consider to get precise estimation of pier scour depth from this equations.

\subsection{Estimation of maximum scour depth}

The main focus of the early researches was the prediction of the ultimate scour depth around bridge piers. Studies showed that scour reaches to an equilibrium level after a while. As a result, if the bridge foundation depth are deep enough than the equilibrium scour depth, the bridge will not be vulnerable during flooding. However, due to uncertainties related to the complex field 
environments such as non-uniform flow distribution and sediment size, irregular shape of geometry, and etc., the scouring is still an important and challengeable research topic. Although using equilibrium scour depth around a bridge pier is a good practice to design a bridge, sometimes it shows an overly conservative design compared to the field measurements. Because peak discharge of floods last for a shorter time than the equilibrium time, scour may not reach to the equilibrium state under those peak discharges during that time (Melville and Chiew, 1999). Contrary to the assumptions provided by Melville and Ciew (1999), a study by Shatanawi et al. (2008) on abutment scour in South Carolina found that at some sites the observed scour depth was greater than 100-year scour depth prediction. However, there was no evidence of a 100-year flood episode since the bridge has been built. Shatanawi et al. (2008) argued that repeated occurrences of smaller flooding events might cause scour that was greater than the scour prediction using 100year flooding.

In general, current methods for computing the total scour depth assume that contraction scour and local scour can be computed in an isolated way and then, they can be added. However, when the bridge is built, contraction scour depth is reduced because of interaction with piers and also both contraction and pier scour occur simultaneously but in different scour development rate (Hong, 2005). So in continuation of this findings, a single equation should be suggested to predict the maximum scour depth. As the contraction in the flow area tends to effect local scour process, we develop a relation to find out the contraction effect on local scour and predict maximum scour depth in an improved way using previously established pier scour equations for designing bridge foundations. As explained by Raudkivi and Ettema (1983), the designer need to have a unifying theory of scour with that they can have much confidence in scour depth predictions. 


\subsection{Methodology of experiments}

In this study, laboratory experiments on bridge scour were conducted by professor Hong at the hydraulics laboratory in the School of Civil and Environmental Engineering at the Georgia Institute of Technology, using a 1:60 scaled down hydraulic model of the Towaliga River bridge (SR-42) of Macon, Georgia including the full river bathymetry as shown in figure 3.1. The Towaliga River is a 52.3 mile long, a tributary of the Ocmulgee River in central Georgia. The Towaliga River passes through High Falls State Park in northwestern of Monroe County, then traverses the county and joins the Ocmulgee River near the town of Juliette. This region is about 50 miles south of Atlanta and about 35 miles north of Macon (figure 3.2). The drainage area of the river at SR-42 bridge over Towaliga River is $816 \mathrm{~km}^{2}$ and a field station was installed and operated by United State Geological Survey (USGS) to measure the water-surface elevation. Thus, the actual discharge amount occurring bridge scour during the extreme hydrologic events can be calculated by using measured rating curve for the bridge.

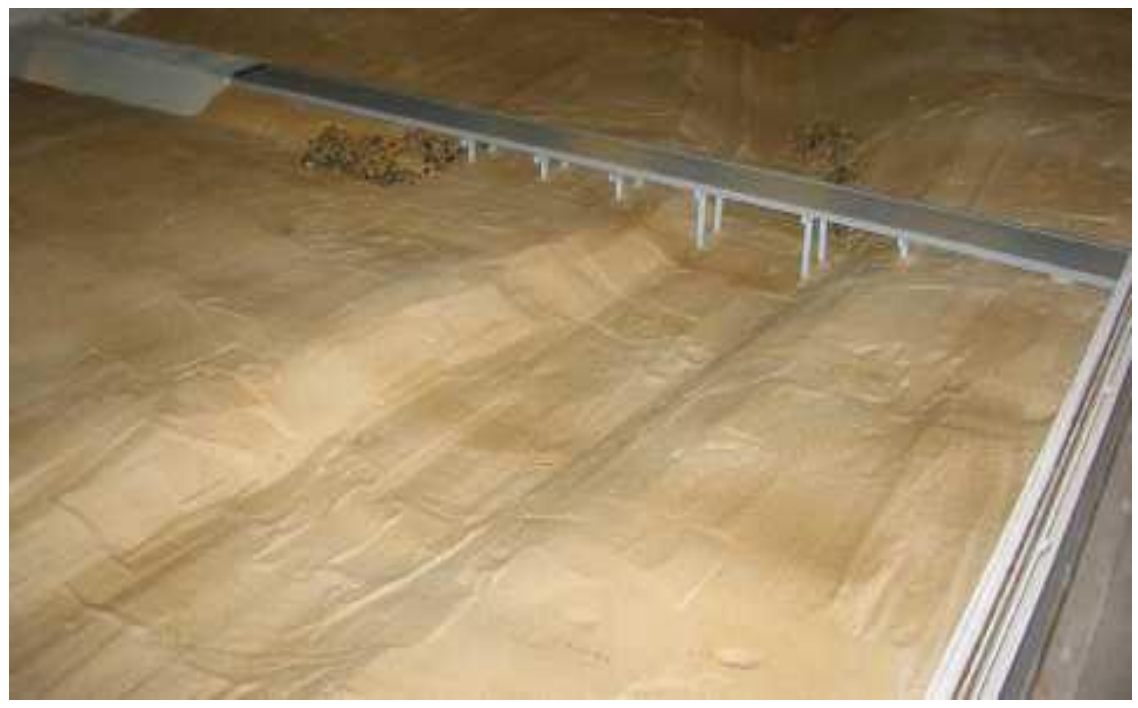

Figure 3.1. Laboratory model of Towaliga River bridge 


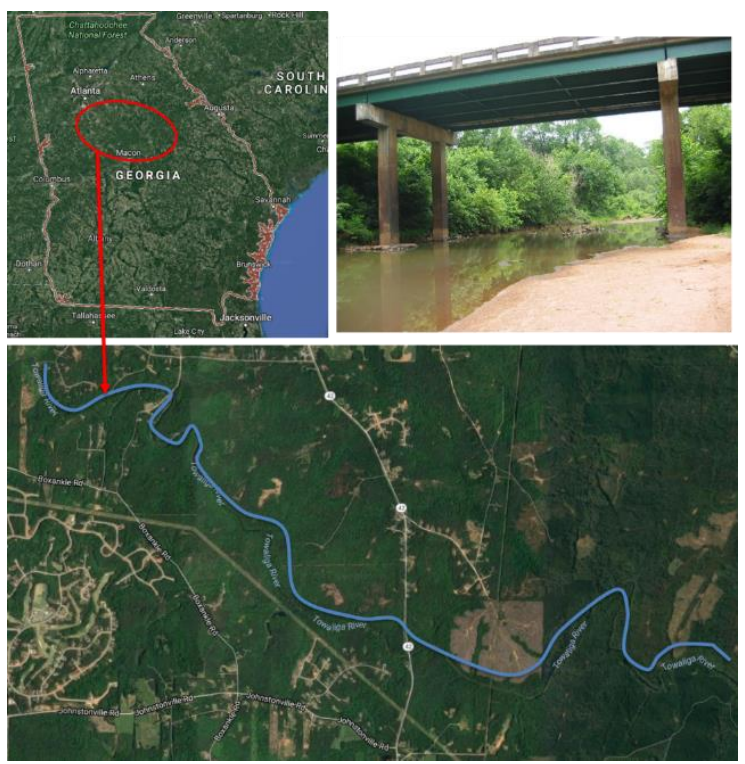

Figure 3.2. Location and view of Towaliga River Bridge

\subsection{Experimental equipment}

\subsubsection{Flume}

The river bathymetry and bridge model were built within the experimental flume having dimensions of $80 \mathrm{ft}$ long, $14 \mathrm{ft}$ wide and $2.5 \mathrm{ft}$ deep. As shown in figure 3.3, water flows into the head box of the flume vertically from the 12-in. supply pipe and the maximum water flow rate is up to $10 \mathrm{ft}^{3} / \mathrm{s}$ supplied by a large constant-head tank. Turbulence at the entrance of the flume was reduced by three chain fences which rolled with a horse-hair filter between the head wall of the flume and an overflow weir. At the downstream of the overflow weir, two baffles were installed one of which is made of offset wood slats and the other of which is a steel plate with $3 / 8$ in. diameter holes having a spacing of 9/16 in. A horse-hair filter was also put in between the two baffles. A tailgate was located at the downstream end of the flume to control the flow depth as demonstrated in figure 3.4. Adjustable rails on the top of the flume walls provided a level track for an instrument carriage. The Acoustic Doppler Velocimeter (ADV), which was used for velocity and bottom elevation measurement and the point gauge for the water surface elevation measurement, were mounted on the carriage and can be moved in three dimensions freely. 


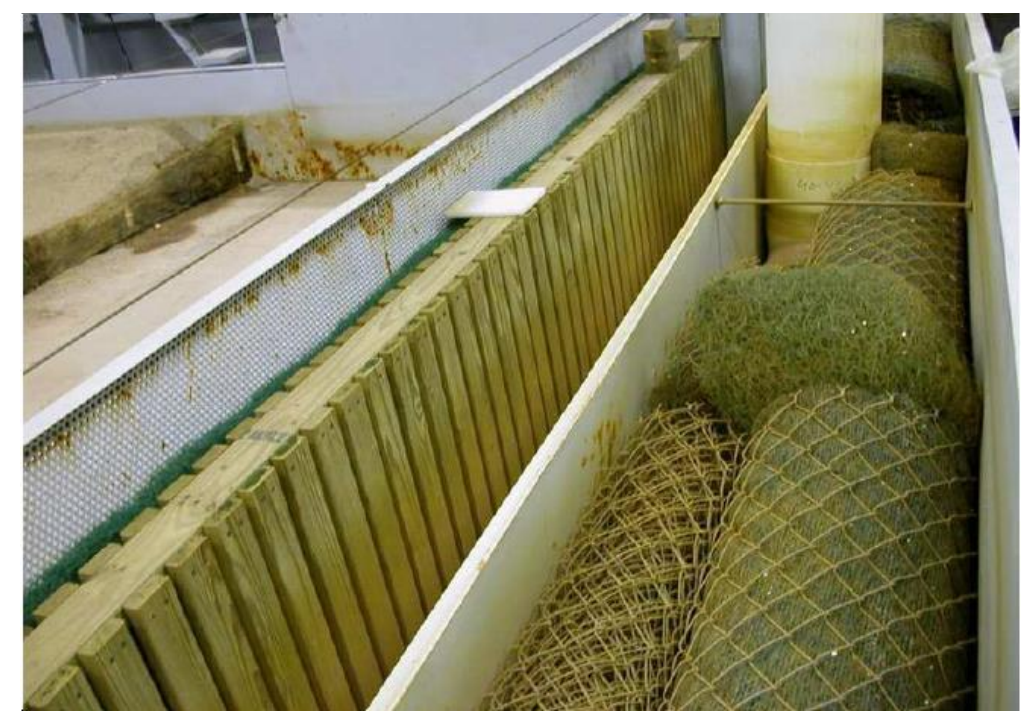

Figure 3.3. Entrance section of the flume

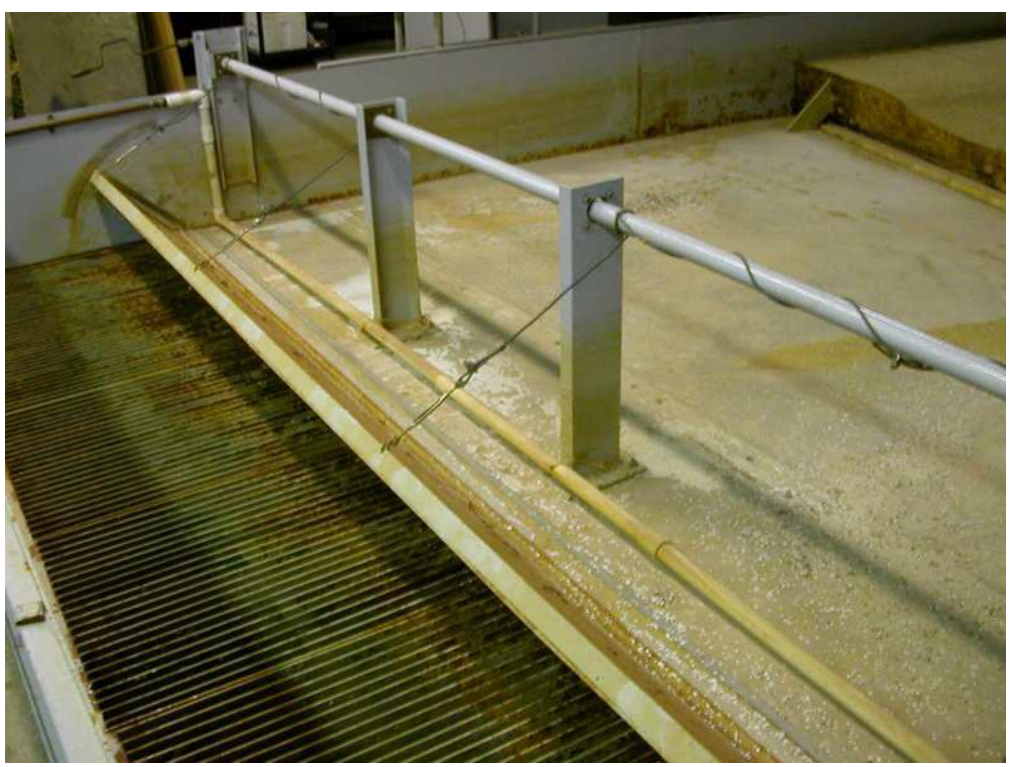

Figure 3.4. Tailgate of the flume to adjust the flow depth downstream

\subsubsection{Flowmeter}

The flow rate was measured by a magnetic flow meter which has an expected uncertainty of $\pm 0.01 \mathrm{ft}^{3} / \mathrm{s}$. 


\subsubsection{Acoustic Doppler Velocimeter (ADV)}

Acoustic Doppler Velocimeter (ADV) was used to measure instantaneous point velocities and turbulence quantities with three dissimilar types of probes: 3D down-looking, 3D side-looking and 2D side-looking. Velocity profiles across the deeper portions of the cross section were measured by a 3D down-looking probe while velocity profiles in shallow floodplain areas in the river models were measured by a 2D side-looking probe. When measurements were required to be taken at points close to the free surface and at shallow water depths, the 2D and the 3D side-looking ADV were used. The ADVs were mounted on a manufactured point gauge located on the steel rail of the instrument carriage.

The operation principle of the ADV is based on the Doppler frequency shift. The ADV measures the velocity in the sampling volume located at the intersection of the transmitted and received acoustic beam. A short pulse of sound at a known frequency from the transmitter propagates through the water. As the pulse passes through the sampling volume, sound is reflected in all directions by particulate matter (sediment, small organisms and bubbles). Some portion of the reflected energy travels back along the receiver beam axes. The reflected signal is sampled by the acoustic receivers and ADV processor measures the change in frequency for each receiver. The Doppler frequency shift measured by the receiver is proportional to the velocity of the reflecting particle that is assumed to move with the same velocity as water.

ADV has an inherent measurement noise. The noise is a result of the physical process by which the sound waves are scattered from particles in the water, and is referred to as Doppler noise. Doppler noise is random and can be assumed to follow a Gaussian distribution. Doppler noise can occur when the flow velocity exceeds the preset velocity range or when there is contamination from the previous acoustic pulse reflected from boundaries of complex geometries. Noise also occurs when a high degree of turbulence exists at the measuring position. One method of dealing with this noise is to filter the data as recommended by the manufacturer (SonTek 2001). Correlation coefficient and signal to noise ratio (SNR) are used primarily as data quality parameters. Correlation coefficient is a quality parameter that is a direct output of the Doppler velocity calculations. Signal strength is a measure of the strength of the return reflection from the water; it can be read as signal to noise ratio (SNR). The criterion for rejecting a time record at a given data point location was set at an overall average correlation coefficient less than $70 \%$, or 
equivalently, if less than $50 \%$ of the data were retained by filtering individual samples below the $70 \%$ correlation value, the entire record for that point location was rejected (Hong et al., 2015). Also, it is recommended by the manufacturer that the signal to noise ratio (SNR) should be greater than 15 for accurate measurements. Typical correlation values in these experiments were greater than $90 \%$ and the SNR was $>15$. The sampling frequency of the ADV was chosen to be $25 \mathrm{~Hz}$ with a sampling duration of 2 minutes at each measuring location based on previous experiments at Georgia Tech. (Hong and Abid, 2015). The water depth and bed elevations before and after scouring were measured by a point gauge and the 3D down-looking ADV. The ADV can detect the distance from the center of the sampling volume to a solid boundary with $\pm 1 \mathrm{~mm}$ uncertainty. When the ADV failed to detect boundary distance along a steep incline, point gauge was used for the measurements.

\subsection{Physical river modeling}

\subsubsection{Model construction}

For the laboratory experiments, a 1:60 scale down physical model was constructed in the hydraulics laboratory at the Georgia Institute of Technology, including full river bathymetry of Towaliga River bridge at Macon, Georgia. Discharge, bed elevation, water level and all other field data measured by USGS were reproduced in the laboratory by using Froude number similarities between model and prototype as shown in following equations. (Hong and Abid, 2015).

$$
\begin{aligned}
& F r_{m}=F r_{p} \Rightarrow \frac{V_{m}}{\sqrt{g Y_{m}}}=\frac{V_{p}}{\sqrt{g Y_{p}}} \\
& \frac{Y_{m}}{Y_{p}}=\frac{1}{60}=L_{r}, \frac{V_{m}}{V_{p}}=L_{r}^{1 / 2}, \frac{Q_{m}}{Q_{p}}=L_{r}^{5 / 2}
\end{aligned}
$$

where, subscript $m$ and $p$ refers to model and prototype, respectively, $F r$ is Froude number, $L_{r}$ is length scale between model and prototype.

As shown in equations (3.1 \& 3.2), dynamic similarity could be achieved by Froude number similarities between field and lab. However, for selecting sediment size in the laboratory study, it is impossible to use same similarity criteria because the scaled sediment size is too small 
that does not exist in prototype stream. Hence, a physically reasonable model strategy is required to select proper model sediment size. Recently developed scour modeling methodology (Melville and Coleman, 2000; Hong and Sturm, 2009; Hong and Abid, 2015) was applied to decide the model sediment size. Selecting sediment size was mostly related to the ratio of pier size to sediment size $\left(a / d_{50}\right)$. The prevailing view in hydraulics community is that if the ratio of pier size to sediment size is greater than 25-50, the scour depth does not depend on sediment coarseness (C. Fael et al., 2006). In the field, the effect of sediment size, $d_{50}$, has not been considered to be important to pier scour because of very large values of $a / d_{50}$ (Lee and Strum, 2009). In the laboratory, pier scour depth to pier size ratio $\left(d_{p s} / a\right)$ tends to increase with $a / d_{50}$ up to a maximum at $a / d_{50} \approx 25$ and seemingly becomes independent of the ratio when $a / d_{50}$ is greater than 50 (Hong and Abid, 2015). However, Sheppard et al. (2004) have suggested that $d_{p s} / a$ may decrease at very large values of $a / d_{50}$ based on experiments in a large flume. Therefore, the value of $a / d_{50}$ can be one of the primary differences between field and laboratory results when considering all parameters affecting local scour around a bridge pier. Thus, sediment size, $d_{50}$, was chosen such that the ratio of pier size to sediment size, $a / d_{50}$ was in the range of $25-50$ where it has negligible influence on pier scour. Furthermore, the ratio of the approach velocity to the critical velocity which concludes the condition of clear water scour regime also an important factor to choose sediment size. Considering all above conditions, the sediment size for this experiment was chosen as $d_{50}=0.53 \mathrm{~mm}$ with $\sigma_{g}=$ 1.2 .

1: 60 scaled down model of SR-42 over Towaliga River was built inside a horizontal flume. The approach section of upstream of the bridge was $24 \mathrm{ft}$ long followed by a $20 \mathrm{ft}$ long moveable working bed section. The $24 \mathrm{ft}$ long approach section was filled with uniform size of small gravel $\left(d_{50}=3.3 \mathrm{~mm}\right)$ to make a fully rough turbulent approach flow. The bridge model was placed into this working bed section. Templates were utilized to reproduce the channel bathymetry. Figure 3.5 shows the experimental layout of the flume. 


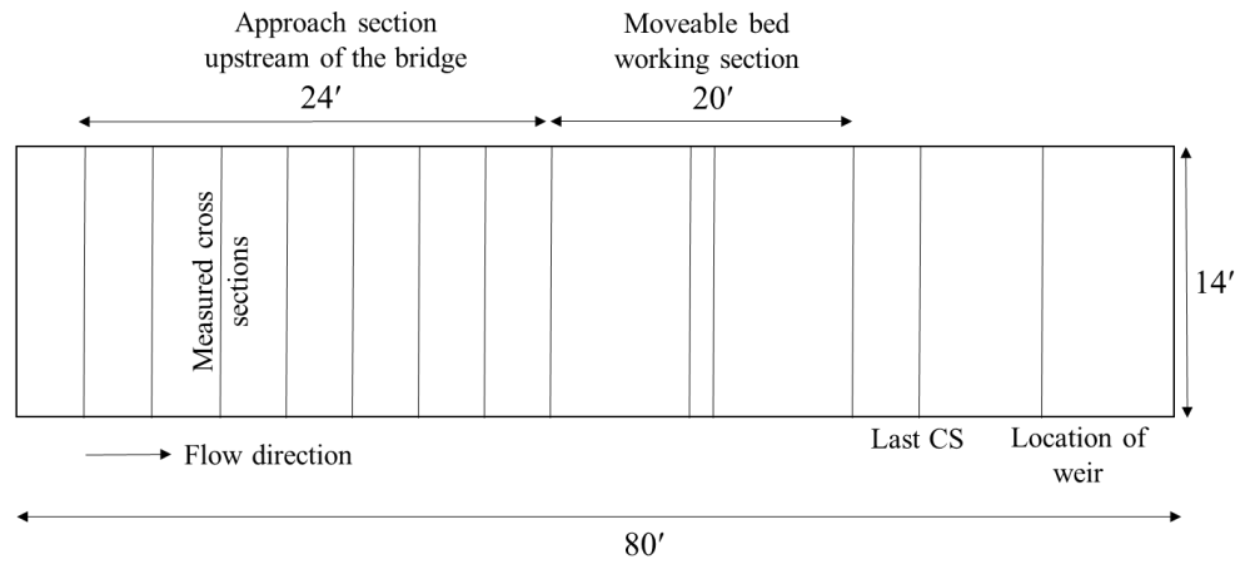

Figure 3.5. Plan view of flume for model construction

In order to reproduce the similar conditions as in the field, the embankment and abutment was built by same size of sand as in the bed and covered with rock rip-rap (Ettema et al., 2006 and Hong et al., 2010). Furthermore, the roadway and bridge deck was modeled and put on top of the embankment. With this approach, bridge overtopping during the extreme amount of hydrologic events as observed in the field can be modeled in the laboratory. Eight piers bents were also modeled in the flume for the experiment. Each of the pier bents was consisted of two in-line rectangular columns. End bents of pier (abutment structures) were buried in the both sides of the erodible embankments (figure 3.6).

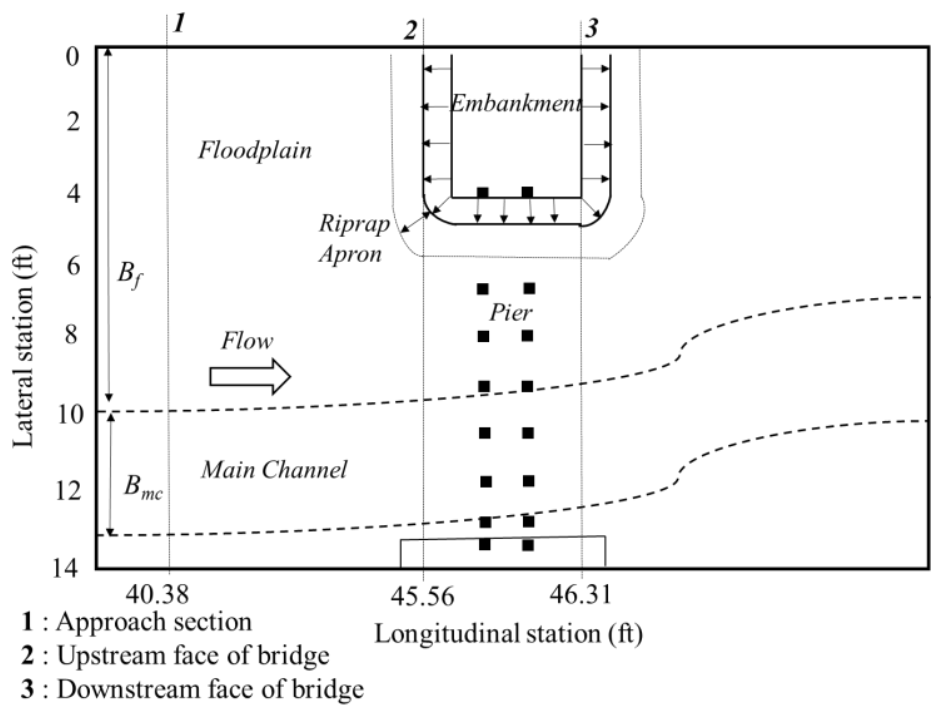

(a) 


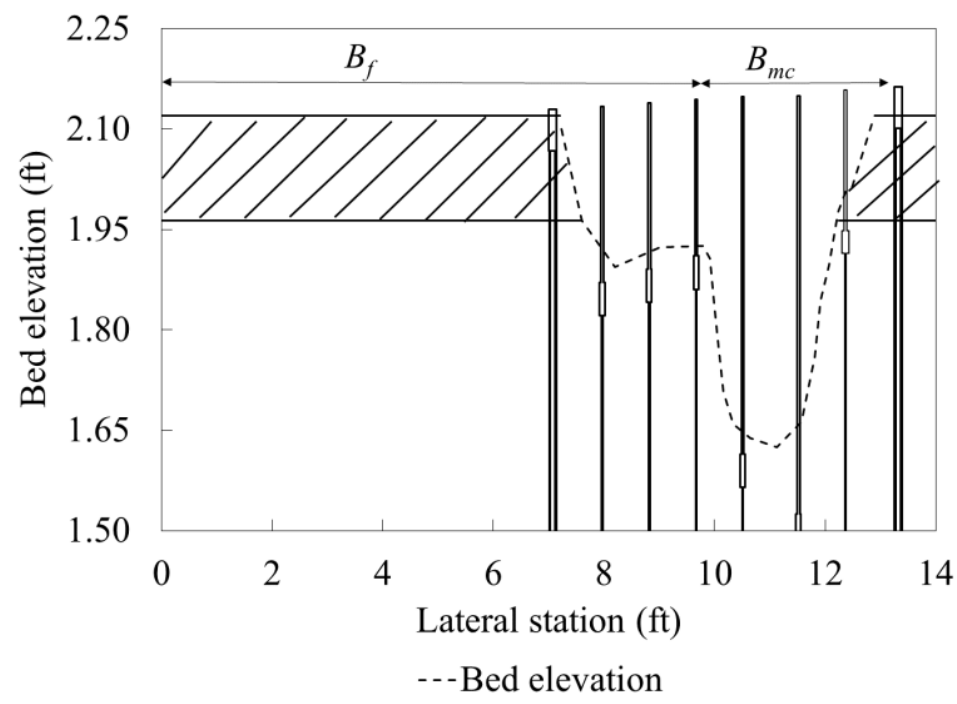

(b)

Figure 3.6. Geometry of compound channel for (a) plan view; (b) cross section view at bridge when looking downstream

\subsubsection{Bed materials}

The size distribution of bed materials was characterized by the sieve analysis. The $d_{50}$ and the geometric standard deviation of the distribution $\left(\sigma_{g}=\left(d_{84} / d_{16}\right)^{0.5}\right)$ were decided by the result from the sieve analysis. If the geometric standard deviation of the distribution is less than 1.5 , it can be considered as uniform size sediments. In the experiment, $\sigma_{g}$ was 1.2 which indicate that uniform bed materials and $d_{50}=0.53 \mathrm{~mm}$ as shown in figure 3.7 . 


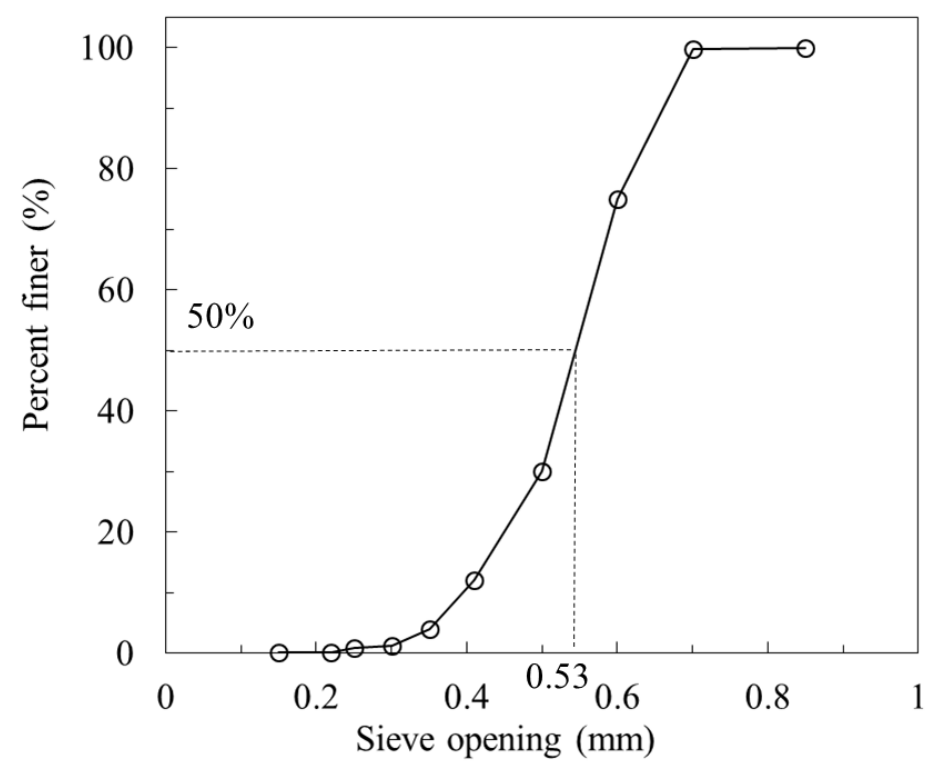

Figure 3.7. Sediment size distribution of the bed material for this study

\subsection{Experimental procedure}

After completion of the model structure, the flume was slowly filled with water from a downstream supply hose to saturate sand without disturbing the initial bottom contours. After complete saturation, the bottom elevations were measured throughout the entire working section using the ADV. After that, a larger flow depth than the required value was set by tailgate, then discharge was increased slowly to prevent initial scour while setting up the test discharge. Then the tailgate was lowered to achieve the desired depth of flow. In the meantime, a point gauge was used to measure the flow depth to measure the targeted water depth. Once the desired flow rate and flow depth was achieved, scouring continued for 5 to 6 days until the equilibrium (change in scour depth less than $2 \%$ within 24 hour) was reached. After reaching equilibrium condition, entire bed elevation were measured by a point gauge and the ADV in detail again to obtain accurate contours after scour.

After finishing the moveable bed experiment, all the movable bed was fixed by spraying polyurethane. In the fixed bed conditions, the initial velocities were measured by ADV in the approach section and bridge section. To measure velocity across the deeper portions of the cross 
section, 3D down-looking probe of ADV was used while a 2D side-looking probe was selected to measure in the shallow floodplain areas.

\subsubsection{Critical velocity assessment}

The flow velocity for initiation of motion of sediment grains is knows as critical velocity $\left(V_{c}\right)$. To determine clear water or live bed scour conditions and to estimate the sediment mobility parameter $\left(V_{1} / V_{c}\right)$, the critical velocity needs to be calculated.

For fully-rough turbulent flow, Keulegan applied the logarithmic velocity distribution to flow in open channel and integrated the Nikuradse fully-rough turbulent velocity distribution over the whole cross section to give the expression as mentioned by Hong (2005),

$$
\frac{V}{u_{*}}=5.75 \log \frac{12.2 R}{k_{s}}
$$

where, $V$ is mean cross-sectional velocity; $u *$ is shear velocity $=\left(\tau_{0} / \rho\right)^{1 / 2} ; \tau_{0}$ is mean boundary shear stress; $\rho$ is fluid density; $R$ is hydraulic radius; and $k_{s}$ is equivalent sand-grain roughness height.

To find the critical velocity, the shear velocity $(u *)$ should be replaced by the critical value of shear velocity $u *_{c}$ in the previous equation as given by,

$$
u_{* c}=\sqrt{\left(\tau_{* c}(S G-1) g d_{50}\right)}
$$

where, $u *_{c}$ is the critical value of shear velocity, $\tau *_{c}$ is Shields parameter, which is equal to $\tau_{c} /\left[\left(\gamma_{s}\right.\right.$ $\left.\gamma) d_{50}\right], \tau_{c}$ is the critical shear stress for incipient sediment motion, $\gamma_{s}$ is the specific weight of sediment, $\gamma$ is the specific weight of fluid and $S G$ is the specific gravity.

Shields parameter is defined by the critical shear stress which is related to the threshold of sediment movement. Using collected experimental data on the initiation of motion and sediment transport, Shields presented the diagram as a dimensionless parameter $\tau *_{c}$ to express the initiation of sediment motion which is a function of the boundary Reynolds number. Later, the Shields diagram was modified by the many other researchers, including Rouse (1939), Yalin (1979) and 
Karahan (1979). In the modified Shields diagram in terms of a dimensionless grain diameter $d *$ expressed as,

$$
d_{*}=\left(\frac{(S G-1) g d^{3}}{v^{2}}\right)^{1 / 3}
$$

Substituting the critical values of velocity and shear stress into equation 3.3, the result of critical velocity is,

$$
V_{c}=5.75 \sqrt{\tau_{* c}(S G-1) g d_{50}} \log \left(\frac{12.2 R}{k_{S}}\right)
$$




\subsection{Results and Analysis}

\subsection{Introduction}

In this chapter, the experimental data are presented and analyzed in terms of nondimensional flow variables and resulting scour depth. The current practice of maximum scour depth prediction requires separate estimates of local scour and contraction scour using different equations resulting from idealized laboratory experiments and adding them in linearly, but local scour and contraction scour may interact so that this addition of the two types of scour resulted in unreliable scour depth compared to the actual field measurement. The results in this research show that maximum clear water scour depth in free and pressure flow can be predicted without considering of separate calculation of different scour components. In the suggested methods, theoretical pier scour depth was used as reference scour depth, and the effect of flow contraction on the maximum scour depth was parameterized with measured flow contraction ratio and the calculated reference scour depth. For the calculations of reference scour depth, two different widely used pier scour equations (CSU and Melville-Sheppard equations) (Arneson et al., 2012) were chosen and investigated the effect of using different method for the calculation of reference scour depth. In the last section of this chapter, area average contraction scour depth was calculated using ambient bed elevation (Hong and Abid, 2015) and correlated with flow contraction ratio. The correlation shows that contraction scour depth increases as flow contraction increases in both pressure and free flow conditions, and pressure flow condition has more scour depth than free flow condition due to the combined effect of lateral and vertical contraction. Also, the effect of presence of a pier bent (located close to abutment) on the maximum scour depth was investigated and summarized in the end of this chapter.

\subsection{Experimental program and velocity measurements}

Total eight experiments (run 1 to 8 ) were conducted for this research using a Towaliga River Bridge model and the experimental conditions have been summarized in table 4.1. Run 9 and 10 have been selected from the previous study by Hong (2011) using different bridge river model to validate the obtained results in this research so that the predicted equation can be used for different hydraulics and geometry conditions. Based on the amount of discharge $(Q)$ and water 
depth, each run has unique flow condition in bridge section; Free (F), Submerged orifice (SO), and Overtopping (OT) flow. Runs 1, 4, 5, and 6 were performed in free flow condition. Remaining runs were conducted in the pressure flow condition. Among them, runs 2 and 7 were categorized as submerged orifice flow (pressure flow without overtopping), and runs 3 and 8 were characterized as overtopping (pressure flow with overtopping). To find the effect of vertical flow contraction due to the existence of a bridge deck, runs 5 and 6 were conducted without bridge deck (removing the bridge deck from the original river model) in exact same flow condition as in runs 2 and 3. Also, to discover the effect of pier located near to abutment on maximum scour depth, pier bent \#7 (located near to abutment) was removed and experiments were conducted in runs 7 and 8. Even if velocities and scour depths were measured in the entire working moveable bed section, only floodplain flow variables and scour depths are presented in this study. The reason behind of choosing only floodplain variables is the maximum scour depth, which is one of the important factor to design the bridge, occurred on the floodplain in all our cases. In addition to the flow types and discharge, other important experimental conditions are presented in table 4.1; mean floodplain cross-sectional flow velocity in the approach and bridge section $\left(V_{1}\right.$ and $\left.V_{2}\right)$, and floodplain hydraulic depth in the approach and bridge section $\left(Y_{1}\right.$ and $\left.Y_{2}\right)$.

Table 4.1. Experimental conditions

\begin{tabular}{ccccccc}
\hline Run & $\begin{array}{c}\text { Flow } \\
\text { type }\end{array}$ & $\boldsymbol{Q}\left(\mathbf{f t}^{\mathbf{3}} / \mathbf{s}\right)$ & $\boldsymbol{V}_{\mathbf{1}}(\mathbf{f t} / \mathbf{s})$ & $\boldsymbol{Y}_{\mathbf{1}}(\mathbf{f t})$ & $\boldsymbol{V}_{\mathbf{2}}(\mathbf{f t} / \mathbf{s})$ & $\boldsymbol{Y}_{\mathbf{2}}(\mathbf{f t})$ \\
\hline 1 & $\mathrm{~F}$ & 1.04 & 0.27 & 0.41 & 0.44 & 0.36 \\
2 & $\mathrm{SO}$ & 1.33 & 0.27 & 0.40 & 0.58 & 0.29 \\
3 & $\mathrm{OT}$ & 1.86 & 0.25 & 0.49 & 0.60 & 0.29 \\
4 & $\mathrm{~F}$ & 1.61 & 0.28 & 0.48 & 0.46 & 0.43 \\
5 & $\mathrm{~F}$ & 1.86 & 0.25 & 0.49 & 0.48 & 0.45 \\
6 & $\mathrm{~F}$ & 1.33 & 0.27 & 0.40 & 0.48 & 0.36 \\
7 & $\mathrm{SO}$ & 1.33 & 0.27 & 0.40 & 0.58 & 0.29 \\
8 & $\mathrm{OT}$ & 1.86 & 0.25 & 0.49 & 0.60 & 0.29 \\
9 & $\mathrm{~F}$ & 3.70 & 0.54 & 0.24 & 0.99 & 0.23 \\
10 & OT & 7.00 & 0.72 & 0.49 & 1.28 & 0.29 \\
\hline \multicolumn{7}{|c}{ (F= free flow, $P=$ Submerged orifice flow, OT=Overtopping) }
\end{tabular}


Velocities were measured at the location shown in figure 4.1 approach section (subscript 1 refers to approach section), upstream face (subscript 2 refers to upstream face of the bridge section) and downstream face (subscript 3 refers to downstream face of the bridge section) of the bridge. The approach cross section was located at a cross section of $40.38 \mathrm{ft}$ in lateral direction from the entrance of flume which was approximately $5 \mathrm{ft}$ upstream from the upstream face of bridge. The center of bridge model was located approximately $46 \mathrm{ft}$ from the entrance of the flume and upstream and downstream face of bridge cross section were located at $45.56 \mathrm{ft}$ and $46.31 \mathrm{ft}$ from the entrance of the flume. At each cross-section, point velocities were measured along multiple vertical transects, and at each vertical transect, point velocities were measured at minimum four points and maximum ten points vertically depending on the depth of water.

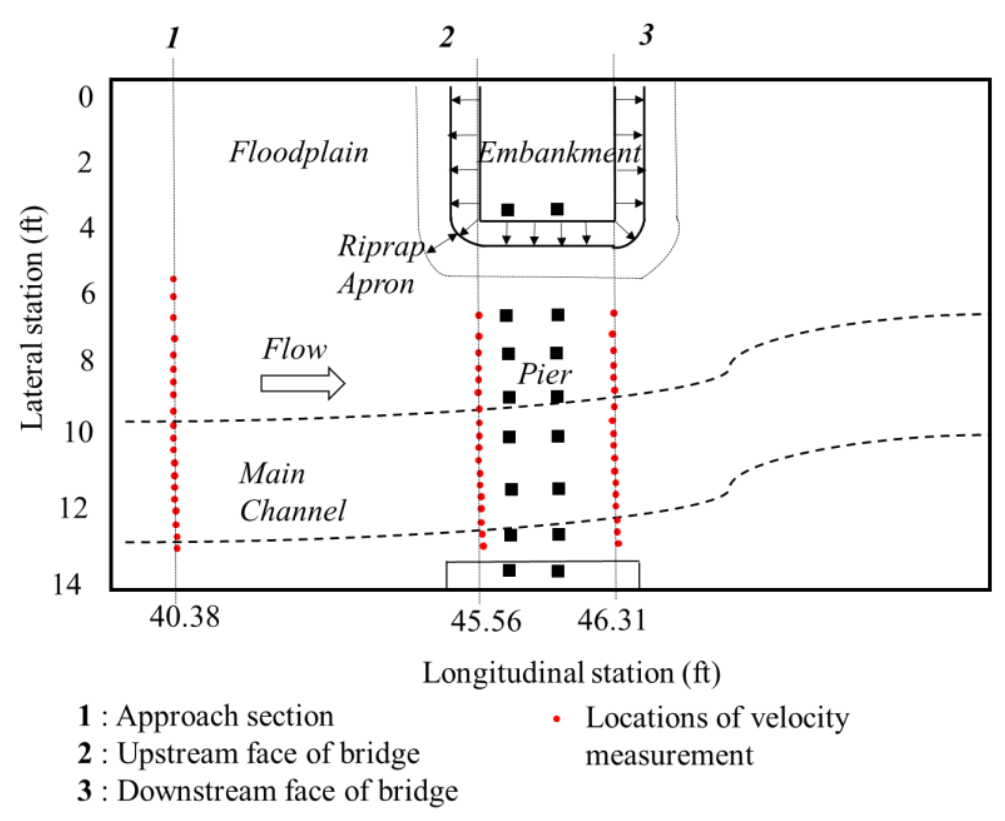

Figure 4.1. Plan view of velocity measurement locations

With the point velocity measurements in each vertical transects, depth-averaged velocities in the approach cross section were determined by the fitting measured data to the logarithmic velocity profile. The depth-averaged velocity was then evaluated as the point velocity from the best-fit log relation at a relative distance above the bed of 0.4 times the depth. However, in the bridge section, the depth-averaged velocities were calculated by taking the integral of the point 
velocity measurements within each vertical velocity profile over the depth and dividing by the water depth because the velocity profile in the bridge section did not have a logarithmic relationship due to its complex three-dimensional behavior (Hong, 2006).

Figure 4.2 shows the depth-averaged velocity distributions at the approach cross-section for run 1. The velocities were higher in the main channel than in the floodplain, as expected for an overbank flow in the floodplain. Figure 4.3 shows lateral distribution of depth-averaged velocity at the upstream face of the bridge section for run 1. Using the depth-averaged velocity as shown in figure 4.2 and 4.3 and measured water depth, cross-sectional mean velocity of floodplain was calculated for the approach and bridge section as presented in table 4.1. In addition to the velocity, discharge per unit width $(q)$ was also calculated with the measured depth-averaged velocity and flow depth in the approach section $\left(q_{1}\right)$ and the bridge section $\left(q_{2}\right)$. The ratio of the discharge per unit width of the bridge section to approach section, as shown in table 4.2, can be used as keyindependent variable that accounts for flow redistribution and resulting flow acceleration through a bridge section. In this study, flow contraction ratio was correlated with non-dimensional scour depth via regression analysis of experimental data.

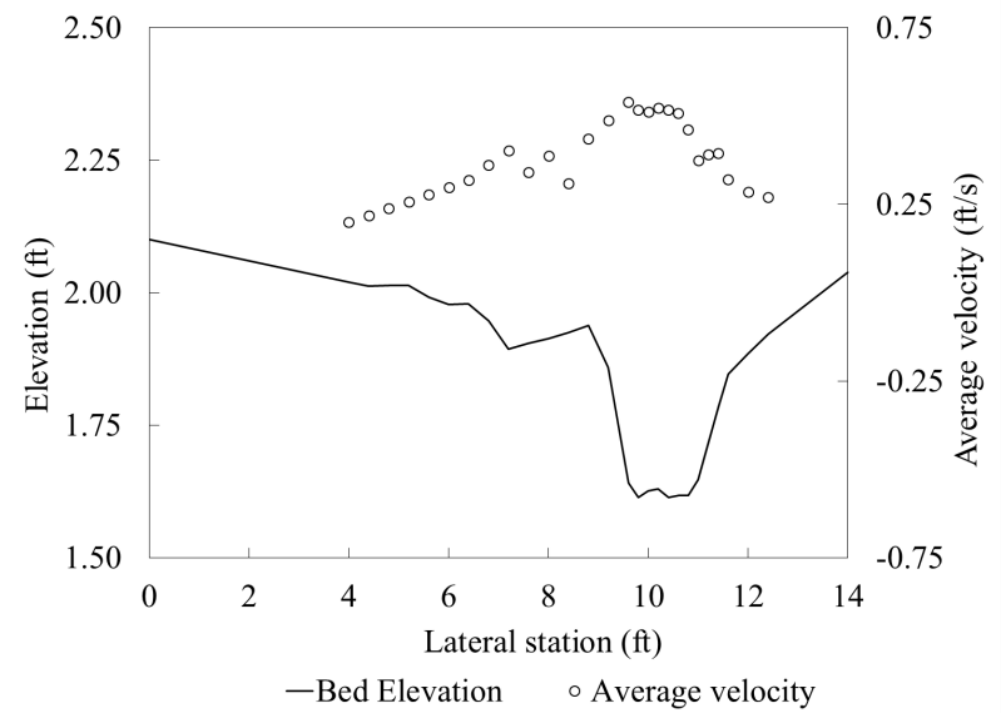

Figure 4.2. Approach flow velocity distributions for run 1 when looking downstream 


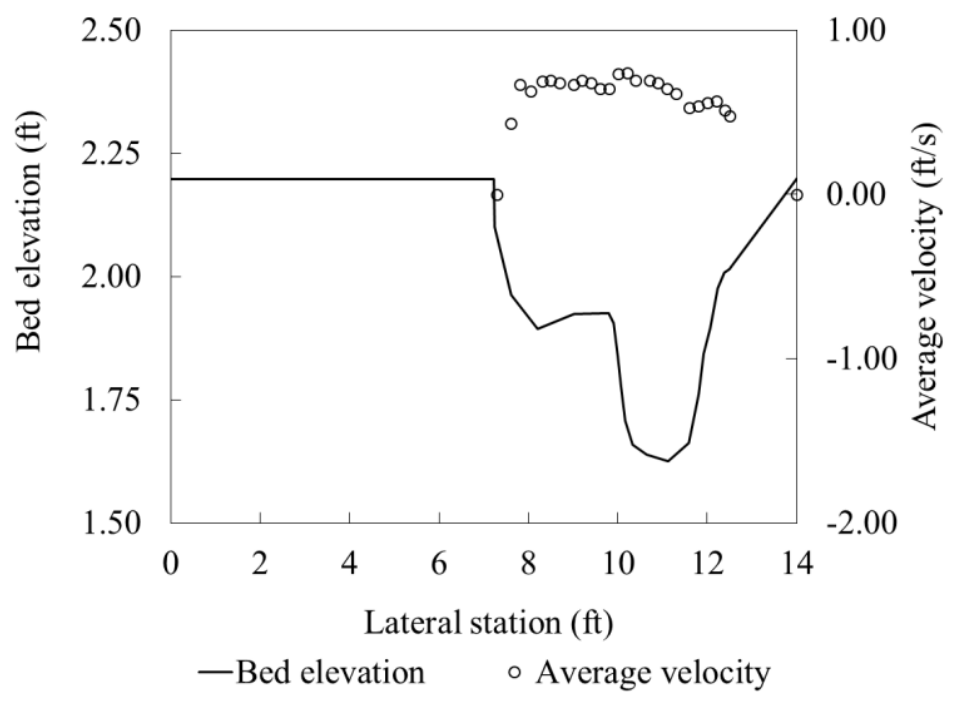

\section{Figure 4.3. Velocity distributions at upstream face of bridge section for run 1 when looking downstream}

\subsection{Verification of physical laboratory modeling}

With the available field measurements, as shown in figure 4.4, scour distribution at the bridge cross sections for runs were compared to validate our modeling strategy. The best comparison between measured bed elevations in the laboratory and observed bed elevations in the field, some measured during Alberto (1994) and others reported after the flood from USGS, is in the case of submerged-orifice flow (run 2). The difference between the scour depth at pier bents \#4 and \#6 in run 2 was reproduced in the laboratory within a few tenths of an inch. Such strong agreement confirmed that the hydraulic modelling procedure using full river bathymetry developed in previous research (Lee et al. 2004, Lee and Sturm 2009, Hong et al. 2015, and Hong and Abid 2016) can be a useful tool for filling the gaps between field and laboratory measurements. 


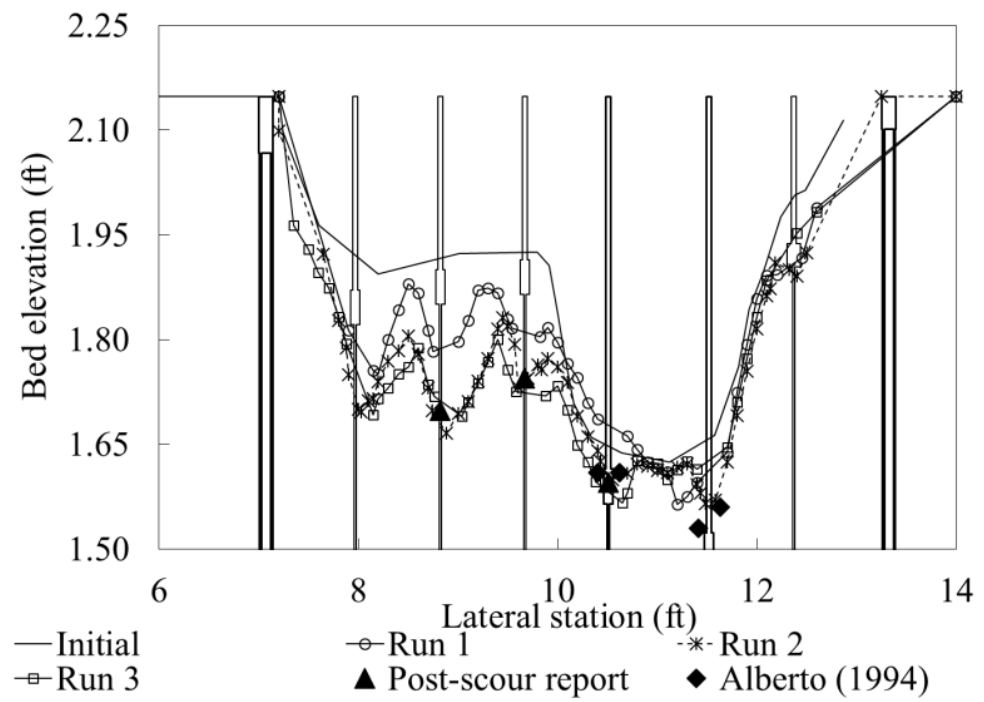

Figure 4.4. Comparison between measured laboratory data and observed field data

\subsection{Location and measurement of the maximum scour depths}

Initial bottom elevations were measured throughout the test section before the experiment and then the final bottom elevations were measured at the same locations after finishing each experiment. Then, to find the location and magnitude of the maximum scour depth, bed elevations after and before the experiments were plotted as shown in figure 4.5. It is obvious that the bed elevation of the downstream face of the bridge section has greater scour depth than the upstream one. But without examining bed contours through the bridge section along the flow direction, the location of maximum scour depth cannot be identified accurately. Thus, Dr. Hong measured three additional cross-section between upstream and downstream face of the bridge section after scour, then compared thoroughly to find the location of maximum scour depth as shown in figure 4.5. The maximum scour depth in all of the laboratory experimental runs was found in the middle of the bridge section in flow direction. As shown in figures 4.5 and 4.6, it is clearly visible that the maximum scour (lowest elevation of the contour) located at the cross section of $45.87 \mathrm{ft}$ from the entrance of the flume for run 2. 


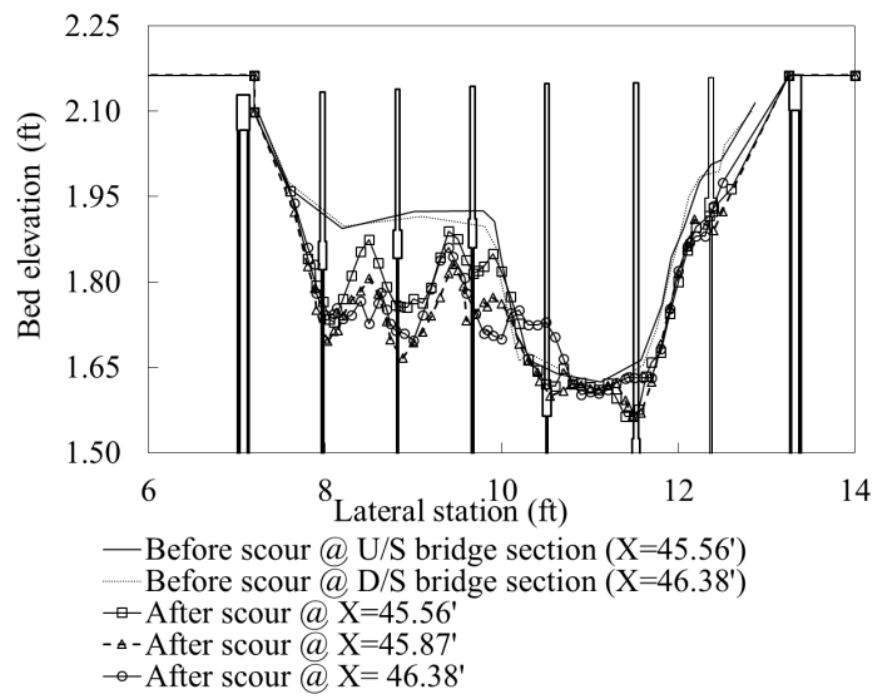

Figure 4.5. Bridge cross-section comparison after scour for run 2

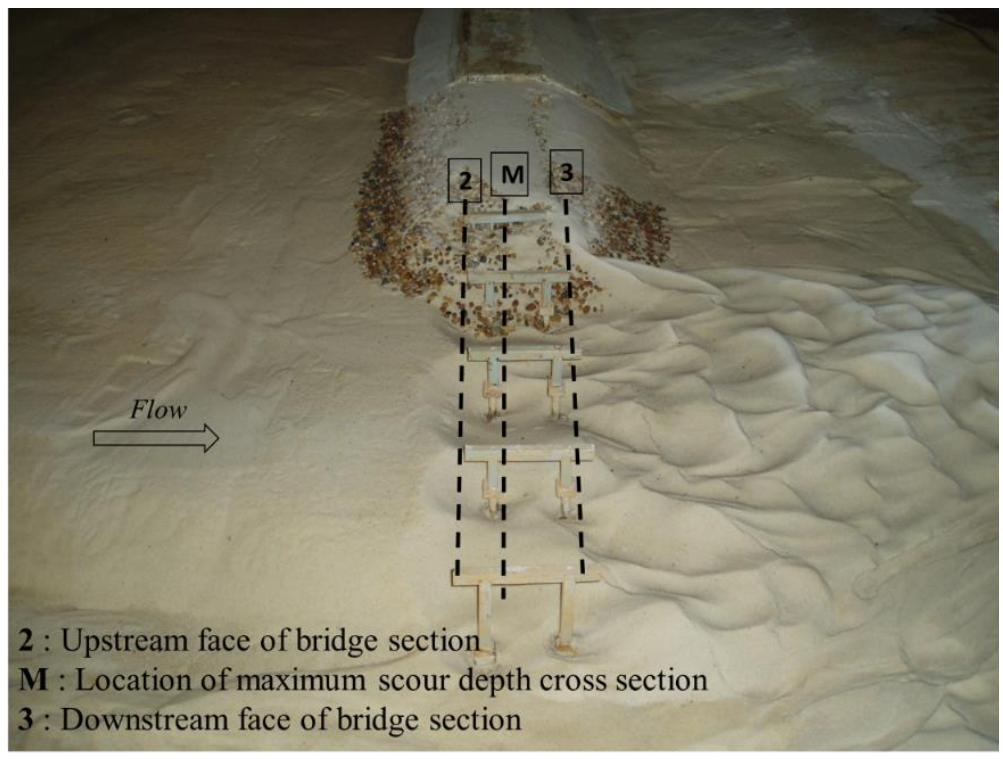

Figure 4.6. Photographs of bed after scour for run 2

In this research, maximum scour depth was expressed as flow depth at the location of maximum scour depth $\left(Y_{m}\right)$. The maximum flow depth after scour in the bridge section was normalized by the approach hydraulic depth $\left(Y_{1}\right)$ to make a non-dimensional variable for further analysis. Figure 4.7 shows a schematic diagram that explain the notation used in the calculation of maximum scour depth. The locations and values of maximum scour depth are shown in table 4.2 
in terms of lateral distance measured from the upstream face of the bridge as well as water depth measured at maximum location of scour.

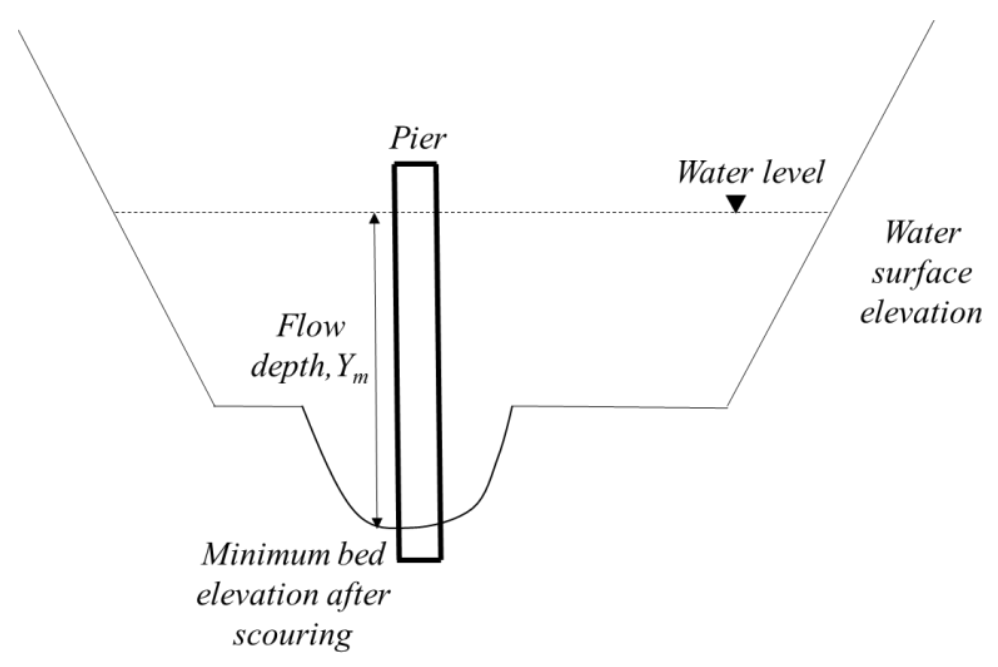

Figure 4.7. Schematic diagram of notations to calculate maximum scour depth

Table 4.2 Summary of maximum scour depth measured location and calculation ( $X=$ distance from upstream face of bridge to maximum scour depth location)

\begin{tabular}{ccccc}
\hline Run & $\begin{array}{c}\text { Flow } \\
\text { type }\end{array}$ & $\boldsymbol{q}_{2} / \boldsymbol{q}_{\mathbf{1}}$ & $\boldsymbol{X}(\mathbf{f t})$ & $\boldsymbol{Y}_{\mathbf{m}}(\mathbf{f t})$ \\
\hline 1 & $\mathrm{~F}$ & 1.45 & 0.40 & 0.57 \\
2 & SO & 1.53 & 0.31 & 0.66 \\
3 & OT & 1.37 & 0.25 & 0.72 \\
4 & F & 1.46 & 0.16 & 0.68 \\
5 & F & 1.71 & 0.16 & 0.69 \\
6 & F & 1.58 & 0.16 & 0.61 \\
7 & SO & 1.53 & 0.61 & 0.66 \\
8 & OT & 1.37 & 0.31 & 0.75 \\
9 & F & 1.71 & & 0.59 \\
10 & OT & 1.05 & & 0.90 \\
\hline
\end{tabular}




\subsection{Reference scour depth calculation}

Two well established theoretical pier scour equations were used to decide the reference scour depth for this research. The most commonly used HEC-18 pier scour equation (also known as CSU equation) predicts maximum theoretical pier scour depth. This equation includes correction factor for pier shape, angle of attack of flow and bed conditions. Using above mentioned correction factors and Froude number $(F r)$ at upstream face of the pier, maximum pier scour depth $\left(d_{c s u}\right)$ has been calculated. NCHRP study (NCHRP 2011a) evaluated 22 pier scour equations and found that although the HEC-18 equation did well in comparison to the other equations, the Sheppard and Miller (2006) equation generally performed better for both laboratory and field data. A second NCHRP study (NCHRP 2011c) made a slight modification of the Sheppard and Miller equation to further improve its performance, which is known as Melville-Sheppard or M/S equation (2011). Using the measured experimental conditions shown in table 4.1, the reference pier scour depth was calculated by HEC-18 and M/S equations, respectively, and the results are shown in table 4.3. More details of the HEC-18 and M/S equations can be found in chapter 2 literature review. 
Table 4.3. Summary of pier scour calculation using HEC-18 and M/S equations

\begin{tabular}{ccccccccccc}
\hline Run & Type & $\begin{array}{c}\text { Pier } \\
\text { number }\end{array}$ & $\boldsymbol{F r}$ & $\boldsymbol{\theta}$ & $\boldsymbol{a}^{*}$ & $\boldsymbol{d}_{\boldsymbol{c s u}}$ & $\boldsymbol{d}_{\mathbf{5 0}, \boldsymbol{f} \boldsymbol{t}}$ & $\boldsymbol{V}_{\boldsymbol{c}}$ & $\boldsymbol{V}_{\boldsymbol{2}} / \boldsymbol{V}_{\boldsymbol{c}}$ & $\boldsymbol{d}_{\boldsymbol{m} \boldsymbol{s}}$ \\
\hline 1 & $\mathrm{~F}$ & $\# 7$ & 0.13 & 20 & 0.031 & 0.094 & 0.002 & 0.96 & 0.46 & 0.019 \\
& & $\# 6$ & 0.13 & 10 & 0.028 & 0.077 & 0.002 & 0.96 & 0.46 & 0.017 \\
2 & SO & $\# 7$ & 0.19 & 22 & 0.031 & 0.106 & 0.002 & 0.93 & 0.63 & 0.051 \\
& & $\# 6$ & 0.19 & 12 & 0.028 & 0.087 & 0.002 & 0.93 & 0.63 & 0.045 \\
3 & OT & $\# 7$ & 0.20 & 15 & 0.029 & 0.095 & 0.002 & 0.93 & 0.64 & 0.048 \\
& & $\# 6$ & 0.20 & 8 & 0.027 & 0.079 & 0.002 & 0.93 & 0.64 & 0.044 \\
4 & F & $\# 7$ & 0.12 & 15 & 0.029 & 0.089 & 0.002 & 0.98 & 0.46 & 0.019 \\
& & $\# 6$ & 0.12 & 8 & 0.027 & 0.074 & 0.002 & 0.98 & 0.46 & 0.017 \\
5 & F & $\# 7$ & 0.13 & 15 & 0.029 & 0.092 & 0.002 & 0.99 & 0.49 & 0.024 \\
& & $\# 6$ & 0.13 & 8 & 0.027 & 0.076 & 0.002 & 0.99 & 0.49 & 0.023 \\
6 & F & $\# 7$ & 0.14 & 22 & 0.031 & 0.101 & 0.002 & 0.96 & 0.50 & 0.029 \\
& & $\# 6$ & 0.14 & 12 & 0.028 & 0.083 & 0.002 & 0.96 & 0.50 & 0.026 \\
7 & SO & $\# 6$ & 0.19 & 12 & 0.028 & 0.087 & 0.002 & 0.93 & 0.63 & 0.045 \\
8 & OT & $\# 6$ & 0.20 & 8 & 0.027 & 0.079 & 0.002 & 0.93 & 0.64 & 0.044 \\
9 & F & & 0.36 & 15 & 0.149 & 0.272 & 0.004 & 1.24 & 0.66 & 0.246 \\
10 & OT & & 0.42 & 15 & 0.149 & 0.313 & 0.004 & 1.29 & 0.68 & 0.264 \\
\hline
\end{tabular}

\subsection{Prediction of maximum scour depth}

The main assumption of our research is that maximum scour depth is consist of theoretical pier scour depth and additional scour due to the flow contraction. So, the equation is,

\section{Maximum scour depth $=$ Theoretical pier scour + Additional scour due to the flow contraction

Theoretical pier scour in Equation 4.1 is predicted using CSU or M/S equation and used it as a reference scour depth. Then, the effect of flow contraction on the maximum scour depth (additional scour) is investigated and parameterized with flow contraction ratio $\left(q_{2} / q_{1}\right)$. The schematic diagram is shown in figure 4.8 with definitions of the variables that will be used for the analysis. $Y_{m}$ is measured flow depth at the location of maximum scour depth listed in table 4.2, and $d_{c s u}$ and $d_{m s}$ is calculated pier scour depth using CSU equation and M/S equation, respectively. Then, "additional scour due to the flow contraction" was determined by the equations below; 
( $Y_{m-c s u}$ is the scour depth that was calculated with using CSU pier scour depth and $Y_{m-m s}$ is the scour depth with using M/S equation), and the results will be analyzed with the measured flow contraction ratio in next sub-section.

$$
\begin{aligned}
& Y_{m-c s u}=Y_{m}-d_{c s u} \\
& Y_{m-m s}=Y_{m}-d_{m s}
\end{aligned}
$$

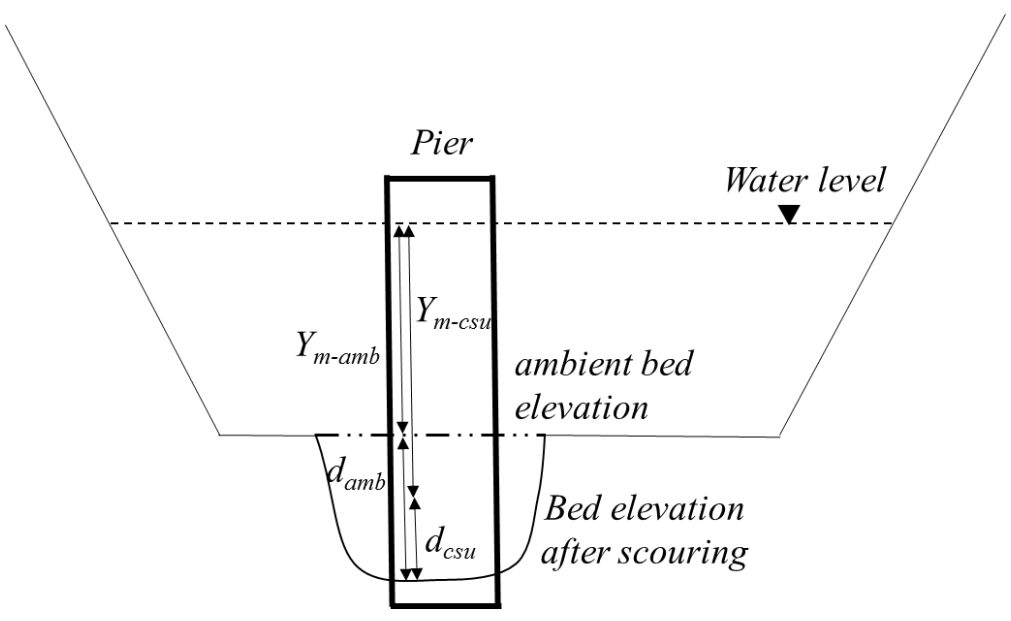

Figure 4.8. Schematic diagram for calculation of contraction scour using flow depth

The additional scour components in equation 4.1 are plotted in figure 4.9 for all three flow types (F, SO, and OT) according to the dimensionless flow variables suggested above. In figure 4.9, CSU pier scour equation was used to decide the additional scour depth. As shown in figure 4.9 , as the $q_{2} / q_{1}$ along the $\mathrm{x}$-axis increases, normalized additional scour depth gradually increases due to the higher flow contraction. As an initial fit, fixed origin $\left(Y_{m-\text { csu }} / Y_{1}=1.0\right.$ as $\left.q_{2} / q_{1}=1.0\right)$ was used in the regression analysis, which would imply that the effect of flow contraction on additional scour is zero when flow contraction ratio approaches to 1.0 (no flow contraction). The results clearly reveal that the effect of flow contraction on additional scour terms becomes higher as the value of $q_{2} / q_{1}$ increases. 


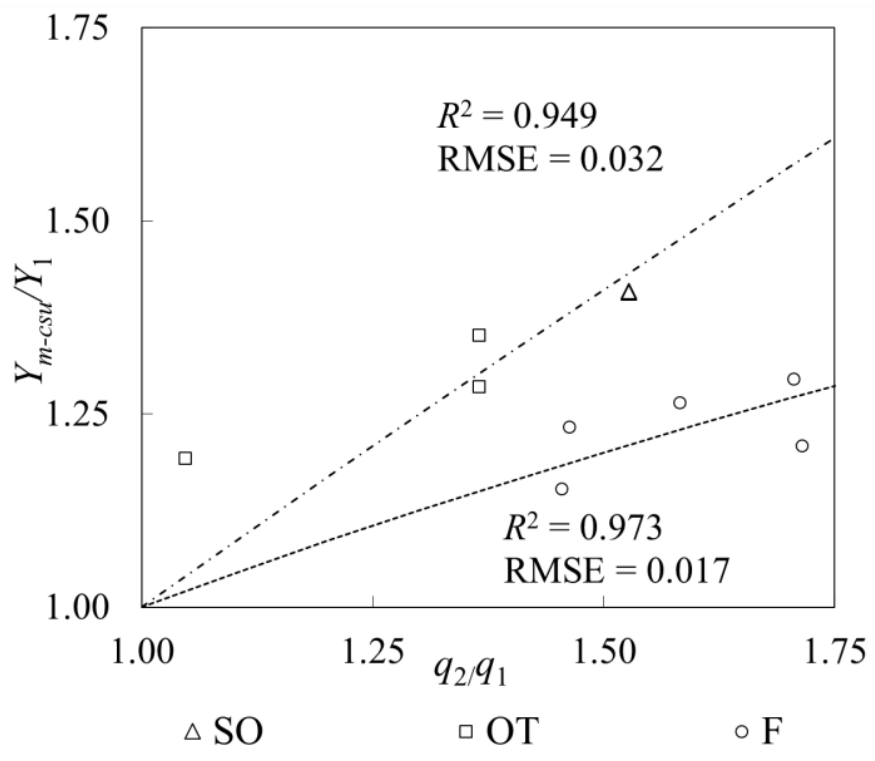

Figure 4.9. Normalized additional scour depth using CSU equation as a function of $q_{2} / q_{1}$

A least-squares regression analysis was conducted on the data given in figure 4.9 with respect to the different flow types (free and pressure flow), and the best-fit equation is given by

$$
\begin{array}{ll}
\frac{Y_{m-c s u}}{Y_{1}}=\left(\frac{q_{2}}{q_{1}}\right)^{0.848} & \text { for pressure flow } \\
\frac{Y_{m-c s u}}{Y_{1}}=\left(\frac{q_{2}}{q_{1}}\right)^{0.450} & \text { for free flow }
\end{array}
$$

For this relationship, coefficients of determination are $R^{2}=0.949$ and 0.973 , and root mean square errors are 0.032 and 0.017 for the pressure flow and free flow, respectively. The regression lines show that pressure flow line has stepper slope than for the free flow cases, and lies above. Because of the vertical flow contraction in addition to the existing lateral flow contraction in pressure flow, the resulting additional scour depth due to the flow contraction is higher than in the free flow cases.

As already explained in the previous paragraph, run 5 and 6 were conducted without bridge deck in exact same flow condition as in run 2 and 3. Thus, the comparison between these runs directly focused the effect of vertical contraction on scour. As shown in figure 4.10, the slope of the regression line for the pressure flow is stepper than for the free flow cases and the difference between this slopes has come directly from the effect of vertical contraction. Although we have 
regression equations for pressure flow and free flow from this analysis, the root mean square value for free flow cases is remarkably higher than pressure flow cases. Also, we had only two sets of same discharge experiments to find out the vertical contraction effect. For this reason, the best-fit equation is not provided here. Further experiments and analysis will improve to understand the effect of vertical contraction in future.

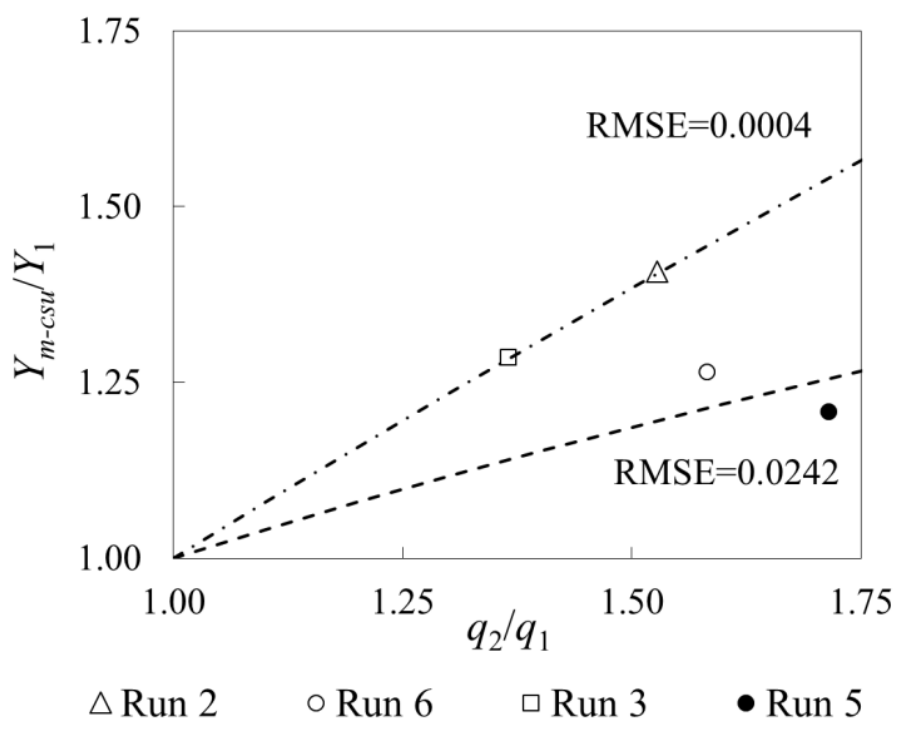

\section{Figure 4.10. Evaluation of vertical contraction effect using normalized additional scour depth as a function of $q_{2} / q_{1}$}

Similar way as in using CSU equation, in figure 4.11, M/S pier scour equation was applied to calculate the additional scour depth and plotted with the value of $q_{2} / q_{1}$. As shown in figure 4.11, additional scour depth calculated using M/S pier scour equation shows similar patterns which is gradually increase over the value of $q_{2} / q_{1}$. However, as shown in below, the regression analysis results show higher value of exponents of $q_{2} / q_{1}$ in the case and smaller value of $R^{2}$ in the case with $\mathrm{M} / \mathrm{S}$ pier scour equation.

$$
\begin{array}{ll}
\frac{Y_{m-m s}}{Y_{1}}=\left(\frac{q_{2}}{q_{1}}\right)^{1.023} & \text { for pressure flow } \\
\frac{Y_{m-m s}}{Y_{1}}=\left(\frac{q_{2}}{q_{1}}\right)^{\mathbf{0 . 6 9 1}} & \text { for free flow }
\end{array}
$$




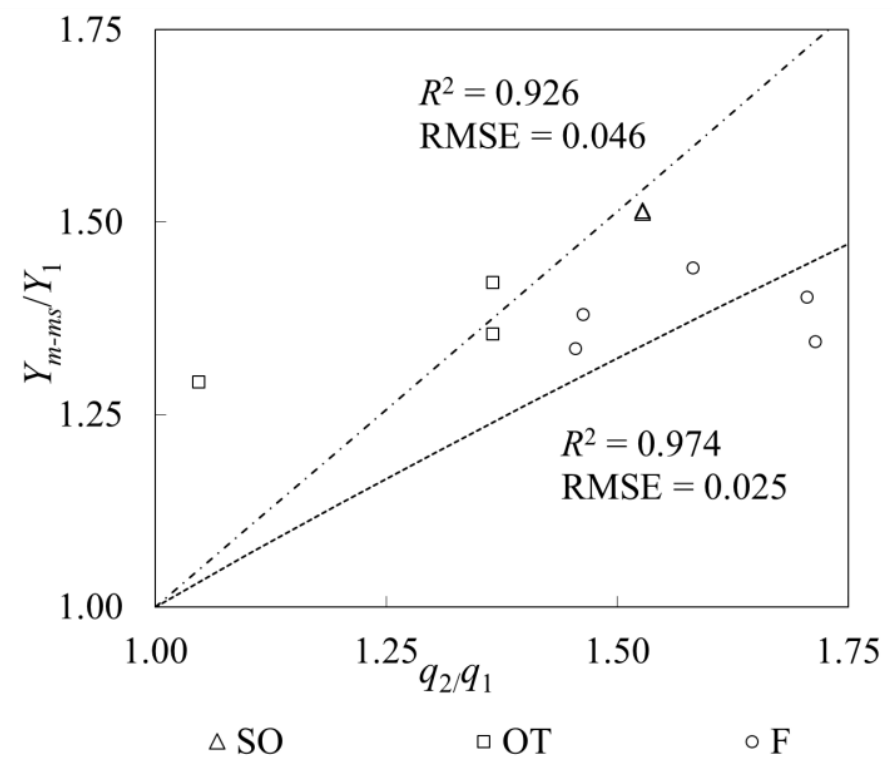

Figure 4.11. Normalized additional scour depth using $\mathrm{M} / \mathrm{S}$ equation as a function of $q_{2} / q_{1}$

Because of the higher value of exponents, the regression lines in figure 4.11 show steeper than the case with CSU equation (figure 4.9). This finding illustrated that the M/S equations shows smaller value of pier scour depth in clear water condition compared to the CSU equation. This is a clear indication that effect of flow contraction on maximum scour depth is higher when the engineer choose to use $\mathrm{M} / \mathrm{S}$ equations as a reference scour depth than using CSU equation. As shown in table 4.3, even in same flow conditions, M/S pier scour depth $\left(d_{m s}\right)$ is smaller than CSU pier scour depth $\left(d_{c s u}\right)$. In figure 4.12, eight experimental data were plotted to compare the ratio of the theoretical pier scour depths calculated using CSU $\left(d_{c s u}\right)$ and M/S $\left(d_{m s}\right)$ equations. Based on the author's understanding, CSU pier scour equation assumes that $V_{2} / V_{c}$ is equal to 1 because almost of the field is live-bed and pier scour depth is normally independent of flow intensity factor in live bed condition; but in $\mathrm{M} / \mathrm{S}$ equation, $V_{2} / V_{c}$ is considered as an individual factor for pier scour depth calculation in each experiment. So, it is obvious that CSU pier scour equation show larger value in clear water condition. However, there is another important difference between CSU and $\mathrm{M} / \mathrm{S}$ equation, which is the consideration of bed material size. But in our cases, 8 out of 10 runs have same sediment size. So, the effect of sediment size cannot be distinguished in pier scour depth comparison in our research. 


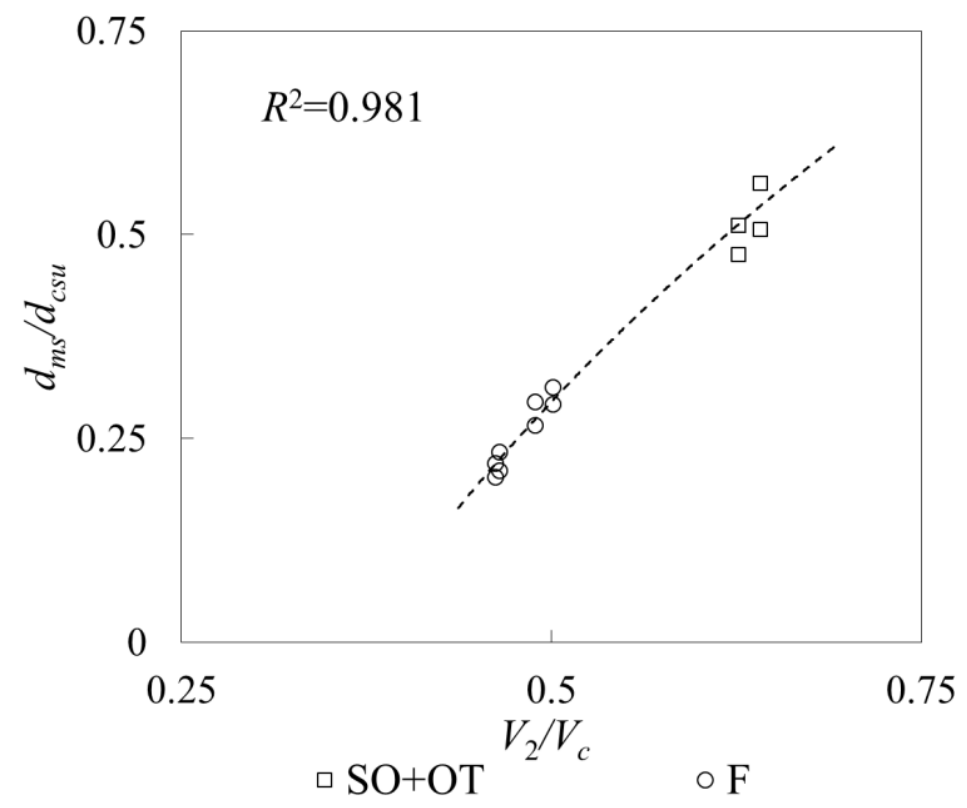

Figure 4.12. Theoretical pier scour depth ratio using CSU and M/S equation in terms of flow intensity

In the above paragraphs, additional scour depth resulting from the flow contraction was derived indirectly by calculating of theoretical local pier scour depth. However, Hong (2005) and Hong and Abid (2015) suggested a method that can be used to remove local scour hole from the measured bridge cross-section. As shown in figure 4.13, pier scour holes were removed by using concurrent ambient bed levels in which bed elevation is established on each side of the pier scour hole around pier and the bed elevations are interpolated between the two as a dashed line. The dashed line can be used as adjusted bed elevation without having local scour holes. Then, ambient pier scour depth $\left(d_{a m b}\right)$ can be decided by the scour depth measured from interpolated dashed line to the lowest point of local scour hole (figure 4.8). Finally, additional scour depth, $\left(Y_{m-a m b}\right)$ can be calculated after excluding $d_{a m b}$ from the maximum water depth at bridge section $\left(Y_{m}\right)$. 


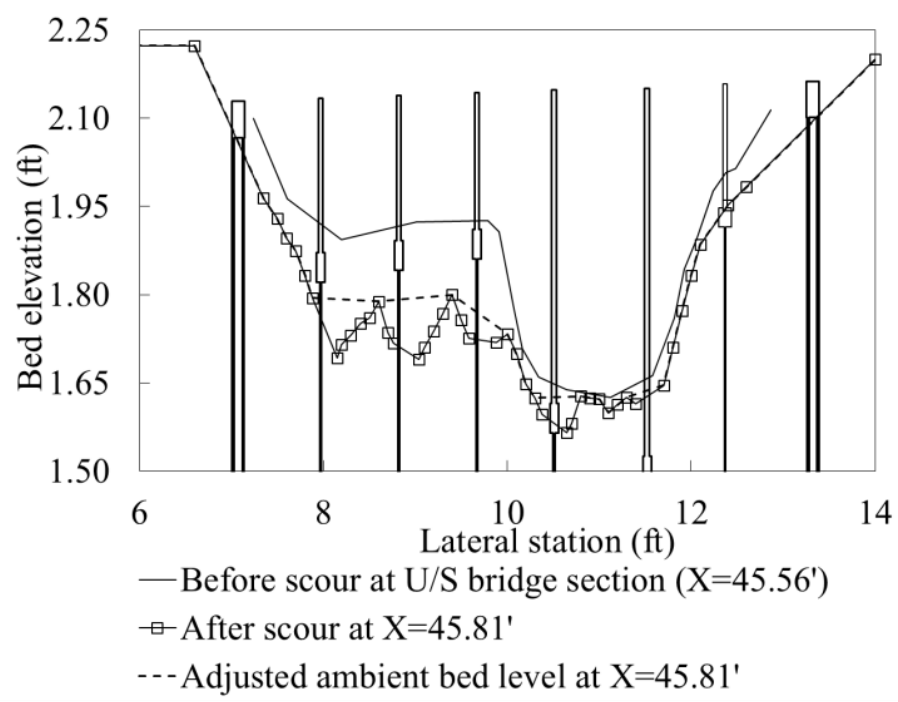

Figure 4.13. Adjusted ambient bed level after scouring of run 3

Figure 4.14 shows the trend of $Y_{m-a m b}$ with respect to the value of flow contraction ratio $\left(q_{2} / q_{1}\right)$. Similar to the cases using theoretical pier scour estimation methods, normalized additional scour depth $\left(Y_{m-a m b} / Y_{1}\right)$ gradually increases as the flow contraction increases. But the slopes of regression lines for both flow types are milder than the cases with using CSU and M/S for the calculation of pier scour depth. The results clearly reveal that in the same flow contraction, the Hong (2005) and Hong and Abid (2015)'s method overestimate the local pier scour depth compared to the other two equations. CSU and M/S equations are only valid for the pier scour depth without any flow contraction. However, the pier scour depth resulting from Hong and Abid (2015)'s methods includes not only theoretical pier scour depth but also the effect of flow contraction on local scour because their experiments were conducted using full river-bathymetry model. Thus, after excluding relatively larger $d_{a m b}$ from maximum scour depth $\left(Y_{m}\right)$, the additional scour terms due to the flow contraction shows smaller than using CSU $\left(Y_{m-c s u} / Y_{1}\right)$ and M/S $\left(Y_{m-}\right.$ ${ }_{m}\left(Y_{1}\right)$.

The results from a least-squares regression analysis for the case of $\left(Y_{m-a m b} / Y_{1}\right)$ are given by,

$$
\begin{array}{ll}
\frac{Y_{m-a m b}}{Y_{1}}=\left(\frac{q_{2}}{q_{1}}\right)^{0.623} & \text { for pressure flow } \\
\frac{Y_{m-a m b}}{Y_{1}}=\left(\frac{q_{2}}{q_{1}}\right)^{0.104} & \text { for free flow }
\end{array}
$$




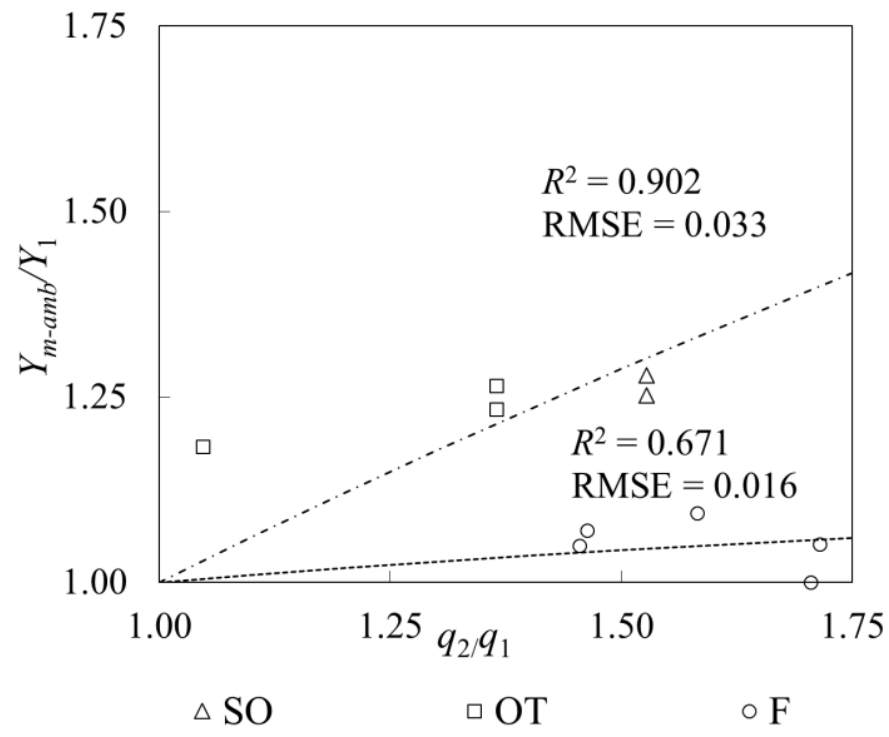

Figure 4.14. Normalized additional scour depth using ambient method as a function of $q_{2} / q_{1}$

The main goal of our research is to develop a methodology to predict maximum scour depth. Based on the assumption shown in equation 4.1 combined with the findings in previous paragraphs, the equations of predicted maximum scour depth for pressure flow conditions are,

$$
\begin{aligned}
& \frac{Y_{m}}{Y_{1}}=\frac{d_{c s u}}{Y_{1}}+\left(\frac{q_{2}}{q_{1}}\right)^{0.848} \\
& \frac{Y_{m}}{Y_{1}}=\frac{d_{m s}}{Y_{1}}+\left(\frac{q_{2}}{q_{1}}\right)^{1.023} \\
& \frac{Y_{m}}{Y_{1}}=\frac{d_{a m b}}{Y_{1}}+\left(\frac{q_{2}}{q_{1}}\right)^{0.623}
\end{aligned}
$$

For the free flow,

$$
\begin{aligned}
& \frac{Y_{m}}{Y_{1}}=\frac{d_{c s u}}{Y_{1}}+\left(\frac{q_{2}}{q_{1}}\right)^{0.450} \\
& \frac{Y_{m}}{Y_{1}}=\frac{d_{m s}}{Y_{1}}+\left(\frac{q_{2}}{q_{1}}\right)^{0.691} \\
& \frac{Y_{m}}{Y_{1}}=\frac{d_{a m b}}{Y_{1}}+\left(\frac{q_{2}}{q_{1}}\right)^{0.104}
\end{aligned}
$$




\subsection{Prediction of contraction effect on local scour}

As explained in the previous sub-chapter, $d_{a m b}$ includes theoretical pier scour depth as well as local pier scour depth due to the flow contraction. Thus, if the additional scour depth using ambient method $\left(Y_{m-a m b}\right)$ excluded from $Y_{m-c s u}$, only contraction effect on local scour is remained.

\section{Contraction effect on local scour $=Y_{m-c s u}-Y_{m-a m b}$}

Using this hypothesis, we plotted flow contraction effect on local scour in different flow conditions. As shown in figure 4.15, normalized contraction effect on local scour increases gradually over the value of $q_{2} / q_{1}$. However, unlikely to the other figures as shown in the previous paragraph, it needs to be point out that in similar value of $q_{2} / q_{1}$, contraction effect on local scour in free flow condition shows higher than in pressure flow condition. Although pressure flow condition includes lateral and vertical contraction, the combined effect of flow contractions on local scour is low. It appears that in pressure flow, vertical contraction combined with lateral contraction make higher contraction scour depth compared to free flow cases. The higher contraction scour depth make relatively lower ambient bed elevation in pressure flow cases. And also, vertical or lateral contraction is not considered in calculation of theoretical pier scour depth by CSU equation. Thus, there is no difference in theoretical pier scour depth for pressure and free flow cases in same discharge. Hence, the difference between ambient bed elevation and theoretical pier scour depth is relatively lower for pressure flow than free flow cases. In our study, this difference is denoted as flow contraction effect on local scour. In summary, vertical contraction increases the average contraction scour depth across the channel width which lower the ambient bed elevation, too. The regression equations for the effect of flow contraction on local scour depth are,

$$
\begin{array}{ll}
\frac{Y_{m-c s u}-Y_{m-a m b}}{Y_{1}}=0.297 * \ln \left(\frac{q_{2}}{q_{1}}\right) & \text { For pressure flow } \\
\frac{Y_{m-c s u}-Y_{m-a m b}}{Y_{1}}=0.395 * \ln \left(\frac{q_{2}}{q_{1}}\right) & \text { For free flow }
\end{array}
$$

For the equation 4.9, coefficients of determination are $R^{2}=0.952$ and 0.931 , and root mean square errors are 0.025 and 0.055 for the pressure flow and free flow respectively, as shown in figure 4.15 . 


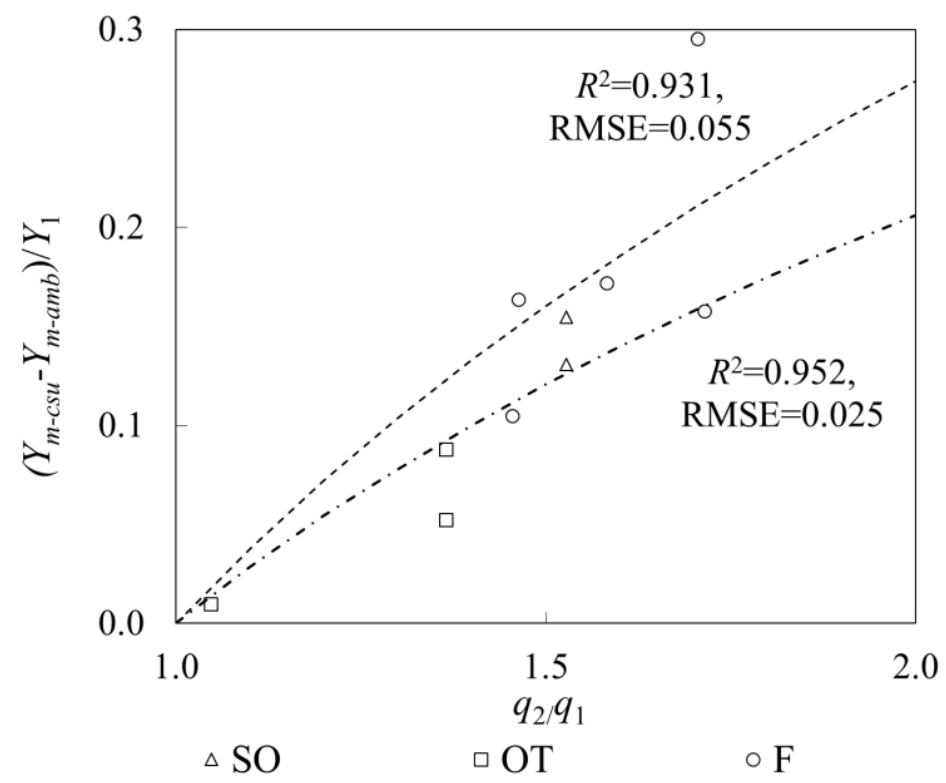

Figure 4.15. Normalized local scour depth due to contraction as a function of $q_{2} / q_{1}$

\subsection{Area average contraction scour depth prediction}

Based on Hong and Abid (2015), area average contraction scour depth has been calculated using ambient bed elevation. This scour depth is denoted as $d_{c s}$ and normalized by approach section flow depth $\left(Y_{1}\right)$ to make a non-dimension variable. A regression analysis has been performed between area average contraction scour depths and flow contraction ratio to find correlation. Figure 4.16 shows that contraction scour depth increases as flow contraction increases in both pressure flow and free flow conditions. But the incremental slope of contraction scour depth for pressure flow is steeper than the free flow. Combination of lateral and vertical contraction make higher contraction scour depth in pressure than solely lateral contraction in free flow cases. The equations of predicted area average contraction scour depth are expressed as,

$$
\begin{array}{ll}
\frac{d_{c s}}{Y_{1}}=1.46 * \log \left(\frac{q_{2}}{q_{1}}\right) & \text { For pressure flow } \\
\frac{d_{c s}}{Y_{1}}=\mathbf{0 . 3 2} * \log \left(\frac{q_{2}}{q_{1}}\right) & \text { For free flow }
\end{array}
$$

Coefficients of determination are $R^{2}=0.98$ and 0.91 , and root mean square errors are 0.035 and 0.023 for the pressure flow and free flow respectively, as shown in figure 4.16. 


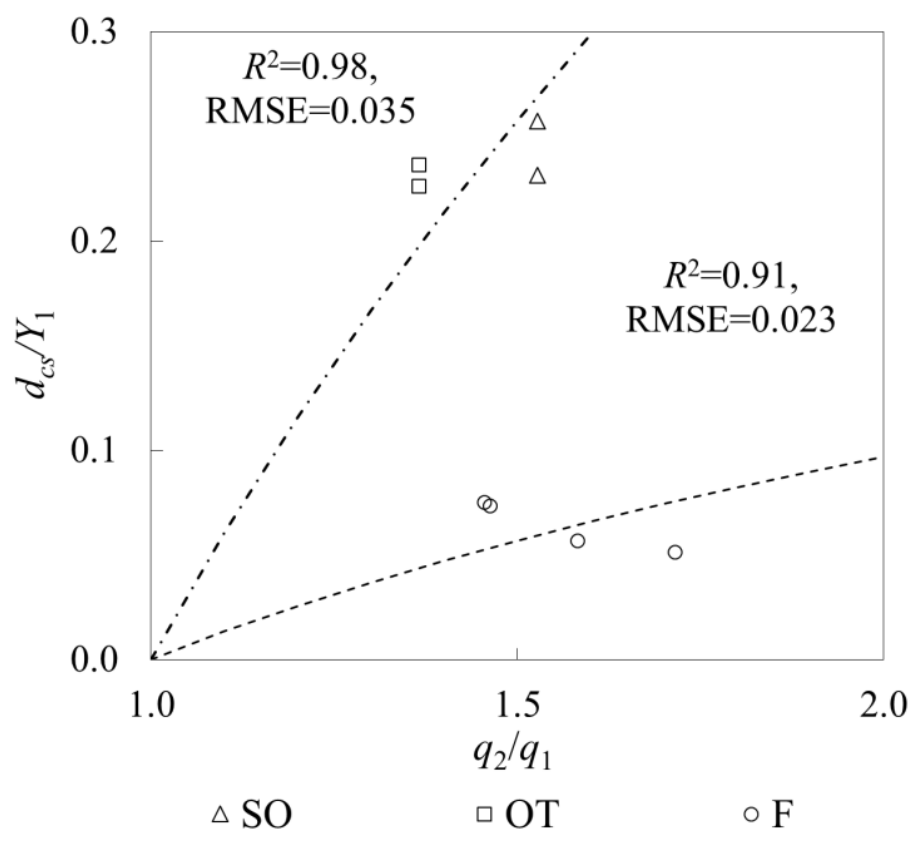

Figure 4.16. Normalized area average contraction scour depth as a function of $q_{2} / q_{1}$

Moreover, to find the effect of pier bent (located near to the abutment) on maximum scour depth, runs 7 and 8 were conducted with same flow condition as in runs 2 and 3 , but removing pier bent \#7 in their bridge section. In both conditions, maximum scour depth located in between upstream and downstream face of bridge section at pier bent \#6. So, the location was not dependent on the presence of closest pier bent (\#7). But the amount of normalized maximum scour depth $\left(Y_{m} / Y_{1}\right)$ was little bit higher in case of run 7 and 8 where pier bent \#7 was absent as shown in table 4.4. Discharge redistribution over the time may be the result for this difference of maximum scour depth.

Table 4.4 shows a summary of all the variables and experimental results, which are required to calculate maximum scour depth. Based on these experimental data, the equations 4.6 and 4.7 have been developed for prediction of the maximum scour depth in an improved way which will remove the difficulties of separating contraction scour and local scour. 
Table 4.4. Summary of experimental results to calculate maximum scour depth

\begin{tabular}{|c|c|c|c|c|c|c|c|c|c|c|c|}
\hline Run & $\begin{array}{l}\text { Flow } \\
\text { type }\end{array}$ & $\underset{\mathbf{f t}^{3} / \mathbf{s}}{Q,}$ & $\begin{array}{c}d_{c s u} \\
\mathbf{f t}\end{array}$ & $\begin{array}{c}d_{m s}, \\
\mathbf{f t}\end{array}$ & $\begin{array}{c}\boldsymbol{d}_{a m b}, \\
\mathbf{f t}\end{array}$ & $\frac{Y_{m}}{Y_{1}}$ & $\frac{q_{2}}{q_{1}}$ & $\frac{Y_{m-a m b}}{Y_{1}}$ & $\frac{Y_{m-m s}}{Y_{1}}$ & $\frac{Y_{m-c s u}}{Y_{1}}$ & $\frac{d_{c s}}{Y_{1}}$ \\
\hline 1 & $F$ & 1.04 & 0.09 & 0.02 & 0.14 & 1.38 & 1.45 & 1.05 & 1.34 & 1.15 & 0.08 \\
\hline 2 & SO & 1.33 & 0.09 & 0.04 & 0.15 & 1.62 & 1.53 & 1.25 & 1.51 & 1.41 & 0.23 \\
\hline 3 & OT & 1.86 & 0.08 & 0.04 & 0.10 & 1.45 & 1.37 & 1.23 & 1.36 & 1.29 & 0.24 \\
\hline 4 & $\mathrm{~F}$ & 1.61 & 0.09 & 0.02 & 0.17 & 1.42 & 1.46 & 1.07 & 1.38 & 1.23 & 0.07 \\
\hline 5 & $\mathrm{~F}$ & 1.86 & 0.09 & 0.02 & 0.17 & 1.39 & 1.71 & 1.05 & 1.35 & 1.21 & 0.05 \\
\hline 6 & $\mathrm{~F}$ & 1.33 & 0.10 & 0.03 & 0.17 & 1.51 & 1.58 & 1.09 & 1.44 & 1.27 & 0.06 \\
\hline 7 & SO & 1.33 & 0.09 & 0.04 & 0.14 & 1.63 & 1.53 & 1.28 & 1.51 & 1.41 & 0.26 \\
\hline 8 & OT & 1.86 & 0.08 & 0.04 & 0.12 & 1.51 & 1.37 & 1.26 & 1.42 & 1.35 & 0.23 \\
\hline 9 & $\mathrm{~F}$ & 3.7 & 0.27 & 0.25 & 0.34 & 2.41 & 1.71 & 1.00 & 1.40 & 1.30 & \\
\hline 10 & OT & 7 & 0.31 & 0.26 & 0.32 & 1.83 & 1.05 & 1.18 & 1.29 & 1.19 & \\
\hline
\end{tabular}




\subsection{Summary and Conclusions}

\subsection{Summary}

Scour hole that is developed around bridge piers can be the main cause of a bridge failure. Thus, predicting maximum scour depth around bridge piers is very important because underestimation of scour depth results in designing shallow foundations, which is dangerous for the bridge safety. Besides, bridge foundations can be designed uneconomically if prediction of scour depth is overestimated.

To suggest a better scour assessment method, the experiments were conducted in clear water condition in three different flow types (free flow, submerged orifice flow and overtopping). At first, scale down bridge river model was constructed in the lab, and a series of experimental tests were conducted in various flow conditions. The tests are comprised of measuring instantaneous three-dimensional velocities and bathymetry, and analysis of the maximum scour depth under various types of flow. Acoustic Doppler Velocimeter (ADV) and point gauge were employed to measure the instantaneous three-dimensional velocity components and water surface elevation respectively.

It was observed that the maximum scour depth was located in between upstream and downstream face of the bridge section. The basic assumption of this research is that maximum scour depth can be summation of theoretical pier scour depth and additional scour depth due to the effect of flow contraction. Based on this assumption, a procedure for predicting maximum scour depth was developed. At first, theoretical pier scour depth was calculated using CSU and M/S equations. Then, the effect of flow contraction on the maximum scour depth was decided by subtracting the theoretical pier scour depth from measured maximum scour depth. The effect of flow contraction on the maximum scour depth, then, correlated with measured flow contraction ratio using regression analysis. The result showed that the contraction effect on maximum scour depth increases as flow contraction ratio increases. In pressure flow case, the effect of flow contraction show larger than in free flow on the maximum scour depth because of additional vertical contraction. The theoretical pier scour equation combined with the regression analysis results using laboratory data, a procedure for predicting the maximum scour depth with respect of bridge design was introduced: 
1. Collecting field geometry data including sediment size;

2. Calculate the flow variables using software or hydraulic laboratory modeling;

3. Compute the theoretical pier scour depth from established pier scour equations (CSU, $\mathrm{M} / \mathrm{S}$ or ambient methods);

4. The additional scour depth due to the effect of flow contraction can be estimated with equations 4.3 or 4.4 or 4.5 depending on the step 3 calculation method;

5. Adding the results from steps 3 and 4 to predict the maximum scour depth for bridge design.

In addition to the design method, an investigation was done to find the effect of contraction on local scour. The result showed that free flow has more effect of contraction on local scour than pressure flow conditions. It may be occurred because of redistribution of flow pattern around the pier due to vertical contraction. Vertical contraction enhances the average contraction scour depth across the channel width which lower the ambient bed elevation. This occurrence changes the flow distribution and make difficult to separate different types scour depth as they occurred concurrently. Moreover, area average contraction scour depth was estimated using ambient bed elevation and correlated with flow contraction. It implies that contraction scour depth increases as flow contraction increases in both pressure flow and free flow conditions. Combination of lateral and vertical flow contraction make higher contraction scour depth in pressure flow than in free flow conditions. An investigation also carried out to find the effect of closest pier bent (located near to abutment) on maximum scour depth. Based on the findings, it can be concluded that location of maximum scour depth was independent of the existence of closest pier bent but absence of closest pier bent increased the scour depth.

\subsection{Conclusions}

Many investigations have been made attempting to estimate the maximum scour depth and to understand the mechanism of scour around bridge piers. Most of the previous investigations were based on the lab experiments using rectangular channel shape in free flow. However, due to the recent extreme rainfall events, submerged orifice flow and overtopping flow occur at the bridge frequently, in which the flow field around the bridge substructure is more complex than in free 
flow because of vertical flow contraction in addition to existing lateral flow contraction. Furthermore, most of the natural channel shape are not rectangular. To overcome these challenges, laboratory experiments were carried out in a scaled down physical model and maximum scour prediction method was suggested that can be used also in pressure flow as well as in free flow cases.

In addition to the reproducing the field geometry in the laboratory by Dr. Hong, My prime contribution of this research is to develop a new scour prediction formula of maximum clear water scour depth using single equation. The current guidelines recommended by HEC-18 assumed that contraction and local scour processes are independent and so they can be determined separately and summed to estimate total scour depth. However, as discussed in chapter 2, during the large flooding events, local scour and contraction scour occur simultaneously, which means time dependent. Thus, a separate calculation of local scour and contraction scour results in inaccurate scour depth. To overcome the weak point that the current methodology has, a single equation was developed to predict maximum scour depth that can be used without separate calculation of different types of scour components.

Even if this study suggested an improved method for the bridge design, following recommendations need to be made for further improvements in the study:

- In this study, all the experiments on scouring were conducted under clear water condition. Scouring occurred either in clear water and live bed conditions, also in mixed conditions. Hence, a well-designed physical model is recommended to investigate the scour characteristics under live bed conditions.

- Abutment scour and its effect on maximum scour depth is not considered in our study. Though an erodible embankment was installed in flume, the lateral distance from the embankment to the maximum scour depth was not considered as a variable to predict maximum scour depth. In future studies, abutment formation, shape and distance can be used as variables to predict equation of maximum scour depth for a wide range of applicability. 
- More laboratory study in wider range of $q_{2} / q_{1}$ could confirm the relationship suggested in this study. Also, additional experiments near $V_{2} / V_{c}=1$ would help to resolve the difference between calculated pier scour depth by CSU and M/S equations.

- Free flow cases show larger flow contraction effect on local scour than in pressure cases based on our findings. However, this results seems questionable because the effect of flow contraction on local scour should be higher in large flow contraction such as in pressure flow cases. A series of experiment need to be conducted to answer the doubtable question.

- Since the research was only conducted on a single, uniform size sediment, future research should incorporate different sediment sizes. In addition, non-uniform size sediment should be incorporated in the future research, as natural rivers generally consist of non-uniform sediment.

- The newly proposed equation may also undergo expanded analysis; for example, its applicability to field results should be further explored. Finally, scour modelling using computational fluid dynamics (CFD) should also be explored to refine the proposed equation for design purposes. 


\subsection{References}

Arneson, L.A., Zevenbergen, L.W., Lagasse, P.F., and Clopper, P.E. (2012). "Evaluating Scour at Bridges", Fifth Edition. FHWA-HIF-12-003, HEC-18. Washington, D. C.: U. S. Department of Transportation, Federal Highway Administration.

Arneson, L. A., and Abt, S. R. (1999). "Vertical contraction scour at bridges with water flowing under pressure conditions." Stream stability and scour at highway bridges, E. V. Richardson and P. F. Lagasse, eds., ASCE, Reston, Va., pp. 189-204.

Barbhuiya, A. K., and Dey, S. 2004. "Local scour at abutments: A review". Sadhana, Academy Proceedings in Engineering Sciences, 29(5), pp. 449-476.

Chabert J and Engeldinger P (1956) "Etude des affonillements author des piles des ponts". Laboratoire National d'Hydraulique de Chatou, Chatou, France.

Chiew, Y. (1984). "Local Scour at Bridge Piers". Ph.D Thesis, Auckland: School of Engineering, University of Auckland, New Zealand.

Cristina Maria Sena Fael, et al. (2006). "Local scour at vertical wall abutments under clear-water flow conditions", Water Resources Research, ASCE 42, pp. 1-12.

Davoren, A. (1985). "Local Scour around a Cylindrical Bridge Pier". Publication No. 3 of the Hydrology Centre, National Water and Soil Conservation Authority, Ministry of Works and Development, Christchurch, New Zealand.

Deng, L. and Cai, C. (2010). "Bridge Scour: Prediction, Modeling, Monitoring, and Countermeasures-Review." Practice Periodical on Structural Design and Construction, 15(2), pp. 125-134.

Dey, S., Raikar, R. (2007). "Characteristics of Horseshoe Vortex in Developing Scour Holes at Piers". Journal of Hydraulic Engineering, 133(4), pp. 399-413.

Dey, S., Bose, S., and Sastry, G. (1995). "Clear Water Scour at Circular Piers: a Model.” Journal of Hydraulic Engineering, 121(12), pp. 869-876. 
Ettema, R., Constantinescu, G., Melville B. (2011) "Evaluation of Bridge Scour Research: Pier Scour Processes and Predictions". National Cooperative Highway Research Program, Document 175. (NCHRP 175).

Ettema, R., Kirkil, G. and Muste, M. (2006). "Similitude of large-scale turbulence in experiments on local scour at cylinders". Journal of Hydraulic Engineering, A.S.C.E., Vol.132 (1), pp 33-40.

Ettema, R. (1980). "Scour at Bridge Piers". PhD Thesis, Department of Civil Engineering, University of Auckland, New Zealand.

Federal Highway Administration. (2012), "Evaluating Scour at Bridges- Fifth Edition. Hydraulic Engineering Circular No. 18". Report No. FHWA-HIF-12-003, U.S. Department of Transportation, Washington, D.C..

Figliola, R.S. and Beasley, D.E. (2011). Theory and Design for Mechanical Measurements: Fifth Edition. USA: John Wiley \& Sons, Inc..

Gill, M.A. (1981). "Bed erosion in rectangular long contraction". Journal of the Hydraulics Division, ASCE 107(3): pp. 273-283.

Ghazvinei, P.T., Ariffin, J., Mohammad, T.A., Amini, S.A., Mir, M.A., Saheri, S., Ansarimohjaddam, S. (2015). "Contraction scour analysis at protruding bridge abutments". Proceedings of the Institution of Civil Engineers - Bridge Engineering, Volume 169 Issue 1, March, 2016, pp. 39-53.

Goel, A. (2015). "Predicting bridge pier scour depth with SVM". World Academy of Science, Engineering and Technology, International Journal of Civil, Environmental, Structural, Construction and Architectural Engineering Vol: 9, No: 2, 2015, pp. 211-216.

Guo, J. (2012). "Pier Scour in Clear Water for Sediment Mixtures.” Journal of Hydraulic Research, 50(1), pp. 18-27.

Hahn, E.M. and Lyn, D.A. (2010). "Anomalous contraction scour? Vertical-contraction case". Journal of Hydraulic Engineering, 136(2): pp. 137-141. 
Hallegatte, S. (2015). "The Indirect Cost of Natural Disasters and an Economic Definition of Macroeconomic Resilience". Policy Research working paper; no. WPS 7357. Washington, D.C.: World Bank Group.

Hamill, L. (1999). “Bridge hydraulics”. London: E\& FN Spon, London.

Holnbeck, Stephen R., Parrett, Charles., and Tillinger, Todd N. (1993). "Bridge scour and change in contracted section, Razor Creek.” Proc., Hydraulic Engineering, ASCE, San Francisco, CA, pp. 2249-2255.

Hong, S., Abid, I. (2015). "Physical Model Study of Bridge Contraction Scour”. KSCE Journal of Civil Engineering, Volume 20, Issue 6, pp 2578-2585.

Hong, S., Sturm, T.W. and Stoesser, T. (2015).” Clear Water Abutment Scour in a Compound Channel for Extreme Hydrologic Events". Journal of Hydraulic Engineering, Volume 141, Issue 6, pp 1-12.

Hong, S. (2011). "Prediction of clear-water abutment scour depth in compound channel for extreme hydrologic events". Ph.D Thesis, School of Civil and Environmental Engineering, Georgia Institute of Technology, Atlanta, Georgia.

Hong, S., and Sturm, T. W. (2010). "Physical modeling of abutment scour for overtopping, submerged orifice, and free surface flows." Proc., $5^{\text {th }}$ Int. Conf. Scour and Erosion, ASCE, Reston, VA.

Hong, S. and Sturm, T.W. (2009). "Physical model study of bridge abutment and contraction scour under submerged orifice flow conditions", 33rd IAHR Congress: Water Engineering for a Sustainable Environment, VANCOUVER, British Columbia, Canada.

Hong, S., Gotvald, A. Sturm, T.W. and Landers, M. (2006). "Laboratory and field measurement of bridge contraction scour", Proc. Third International Conference on Scour and Erosion, CURNET, Gouda, Netherlands.

Hong, S. (2005). "Interaction of Bridge Contraction Scour and Pier Scour in a Laboratory River Model." Master's thesis, Georgia Institute of Technology. 
Johnson, P. A. (1995). "Comparison of pier-scour equations using field data". Journal of Hydraulic Engineering, 121(8): pp. 626-629.

Kalantari, O. (2014). "Time-Dependent Local Scour of Circular Bridge Pier". PhD Thesis, University of Nebraska-Lincoln, Lincoln, Nebraska.

Kattell, J. and Eriksson, M. (1998). "Bridge Scour Evaluation: Screening, Analysis, and Countermeasures”. Gen. Tech. Rep. 9877 1207-SDTDC, U.S. Department of Agriculture, San Dimas, CA.

Khwairakpam, P., Ray, S.S., Das, S., Das, R., Mazumdar, A. (2012). "Scour hole characteristics around a vertical pier under clearwater scour conditions". ARPN Journal of Engineering and Applied Sciences, Vol. 7, No. 6, pp. 649-654.

Komura, S. (1966). "Equilibrium depth of scour in long constrictions". Journal of the Hydraulics Division, ASCE 92(5): pp. 17-37.

Laursen, E.M. (1963). "An analysis of relief bridge scour". Journal of the Hydraulic Division, ASCE 89(3): pp. 93-109.

Lee, S. O. and Sturm, T.W. (2009). "Effect of sediment size scaling on physical modeling of bridge pier scour", Journal of Hydraulic Engineering, ASCE 135, no 10, pp. 793-802.

Lee, S.O. (2006). "Physical modeling of local scour around complex bridge piers". PhD Thesis, School of Civil and Environmental Engineering, Georgia Institute of Technology, School of Civil and Environmental Engineering, Georgia Institute of Technology, Atlanta, US.

Lee, S. O., Sturm, T. W., Gotvald, A., and Landers, M. (2004). "Comparison of laboratory and field measurements of bridge pier scour". Proc. 2nd Int. Conf. on Scour and Erosion, Singapore, pp. 231-239.

Lee, K.G. and Hedgecock, T.S. (2007). "Clear-Water Contraction Scour at Selected Bridge Sites in the Black Prairie Belt of the Coastal Plain in Alabama, 2006". Scientific Investigations Report, Alabama Water Science Center, Geological Survey (U.S.), viii, pp. 57.

Lim, S.Y. (1997). "Equilibrium clear-water scour around an abutment". Journal of Hydraulic Engineering, 123(3): pp. 237-243. 
Lyn, D. A. (2008). "Pressure-flow scour: A re-examination of the HEC-18 equation." Journal of Hydraulic Engineering, 134(7), pp. 1015-1020.

Melville, B. W., and Coleman, S. E. (2000). “Bridge scour”, Water Resources Publications, LLC, Highlands Ranch, Colorado, U.S.A.

Melville, B., and Chiew, Y. (1999). "Time Scale for Local Scour at Bridge Piers.” Journal of Hydraulic Engineering, 125(1), pp. 59-65.

Melville, B.W. (1997). "Pier and abutment scour: integrated approach". Journal of Hydraulic Engineering, 123(2): pp. 125-136.

Melville, B.W. (1975). “Local scour at bridge sites”. Report no. 117, School of Engineering, The University of Auckland, Auckland, New Zealand.

Mueller, D. S. (1996). "Local scour at bridge piers in nonuniform sediment under dynamic conditions". Ph.D. thesis, Colorado State University Fort Collins, Colo, USA.

Najafzadeh, M., Shahidi, A.E., Lim, S.Y. (2016). "Scour prediction in long contractions using ANFIS and SVM”. Ocean Engineering, Volume 111, 1 January 2016, pp. 128-135.

Novey, M. (2013). "CDOT assessing 'millions and millions' in road bridge damage". www.coloradoan.com, Sep. 15, 2013.

Oben-Nyarko, K. and Ettema, R. (2011). "Pier and Abutment Scour Interaction". Journal of Hydraulic Engineering, Volume 137, Issue 12, pp. 1598-1605.

Ozturk, N., Azie, A., Besir, S. (2008). "Flow Details of a Circular Cylinder Mounted on a Flat Plate”. Journal of Hydraulic Research, 46(3), pp. 344-355.

Qadar, A. (1981). "Vortex Scour Mechanism at Bridge Piers." Proceedings of the Institution of Civil Engineers, London, England, pp. 739-757.

Raudkivi, A.J. and Ettema, R. (1983). "Clear-water scour at cylindrical piers". Journal of Hydraulic Engineering, 109(3): pp. 338-350.

Richardson, E., and Davis, S. (2001). "Evaluating Scour at Bridges,” Fourth Edition. Federal Highway Administration, Washington, D.C. 
Rouse, H. (1939). "Criteria for similarity in the transportation of sediment". Proc. Hyd. Conf. Studies Engineering Bull., Univ. of Iowa, pp 33-49.

Schreider, Mario., Scacchi, Graciela., Franco, Felipe., and Romano, Carlos. (2001). "Contraction and abutment scour in relief bridge in a flood plain", Proc., Wetlands Engineering and River Restoration, ASCE, Reno, NV, pp. 1375-1386

Shatanawi, K.M., Aziz, N.M. and Khan, A.A. (2008). "Frequency of discharge causing abutment scour in south carolina", Journal of Hydraulic Engineering, ASCE 134, no. 10, pp. 15071512.

Shen, J., Shan, H., Suaznabar, O., Xie, Z., Bojanowski, C., Lottes, S., Kerenyi, K. (2012). "Submerged-flow bridge scour under clear-water conditions". 6th International Conference on Scour and Erosion (ICSE6-216), Paris, pp. 755-760.

Shen, H. W., Schneider, V. R. and Karaki, S. (1969). "Local scour around bridge piers”. Proc. ASCE. 95(6): pp. 1919-1940.

Sheppard, D., Melville, B., Demir, H. (2014). "Evaluation of Existing Equations for Local Scour at Bridge Piers”. Journal of Hydraulic Engineering, Volume 140 Issue 1, pp. 14-23.

Sheppard, D. and Miller, W. (2006). “Live-Bed Local Pier Scour Experiments.” Journal of Hydraulic Engineering, 132(7), pp. 635-642.

Sheppard, D., Odeh, M., and Glasser, T. (2004). "Large Scale Clear-Water Local Pier Scour Experiments.” Journal of Hydraulic Engineering, 130(10), pp. 957-963.

Shrestha, C. K. (2015). "Bridge Pier Flow Interaction and Its Effect on the Process of Scouring". Ph.D. dissertation, University of Technology Sydney (UTS).

Shirhole, A. M., and Holt, R. C. (1991). "Planning for a comprehensive bridge safety program". Transportation Research Record No. 1290: Transportation Research Board, National Research Council, Washington.

Simpson, R. L. (2001). “Junction Flows”. Annual Review of Fluid Mechanics, vol. 33, pp. 415443. 
SonTek (2001). "Acoustic Doppler Velocimeter (ADV) principles of operation", SonTek Technical Notes, SonTek, San Diego, CA.

Stamey, T. C. (1996). "Summary of data-collection activities and effects of flooding from tropical storm Alberto in parts of Georgia, Alabama, and Florida, July 1994”. U.S. Geological Survey, Georgia Department of Transportation, Atlanta, Georgia.

Sturm, T.W., Ettema, R., and Melville, B.M. (2011) "Evaluation of bridge-scour research: Abutment and contraction scour processes and prediction" NCHRP p 24-27(02), National Co-operative Highway Research Program, Washington D.C., U.S.A.

Sturm, T.W. (2001). Open Channel Hydraulics. Text book series in Water resources and Environmental Engineering, McGraw-Hill, NY.

Tejada, S. (2013). "Effects of blockage and relative coarseness on clear water bridge pier scour". Master's thesis, University of Windsor, Ontario, Canada.

Umbrell, E. R., Young, G. K., Stein, S. M., and Jones, J. S. (1998). “Clear-water contraction scour under bridges in pressure flow.” J. Hydraul. Eng., 124(2), pp. 236-240.

Williams, P. D. (2014). "Scale effects on design estimation of scour depths at piers". Master's thesis, University of Windsor, Ontario, Canada.

Yalin, M.S., and Karahan, E. (1979). “Inception of sediment transport”, Journal of Hydraulic Div., ASCE 105, no. HY11, pp. 1433-1443. 
APPENDIX A

Final Bed Elevation Pictures 


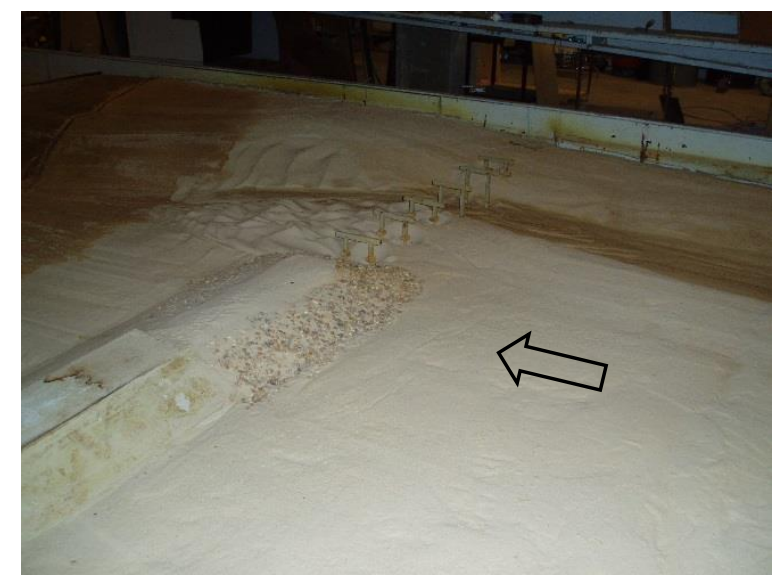

(a)

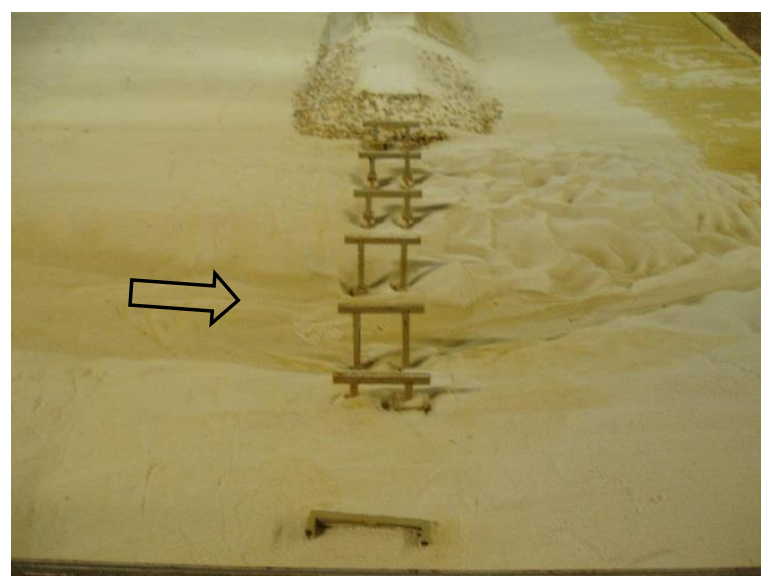

(c)

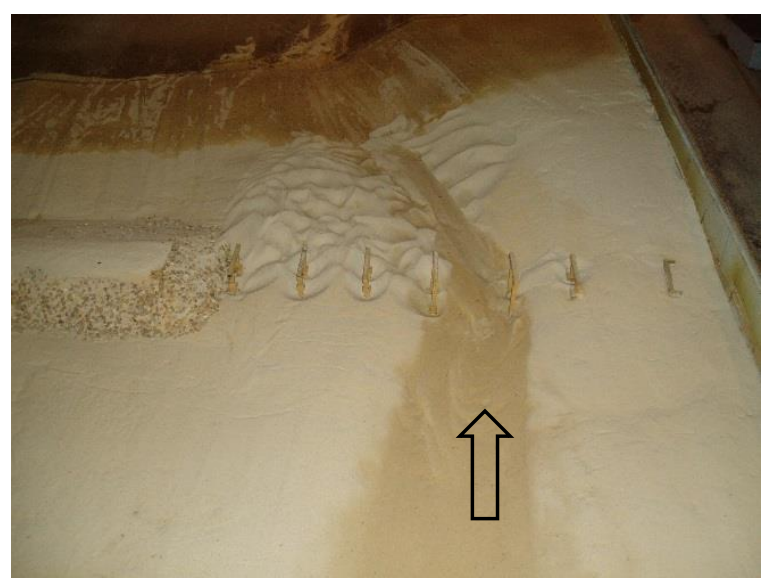

(e)

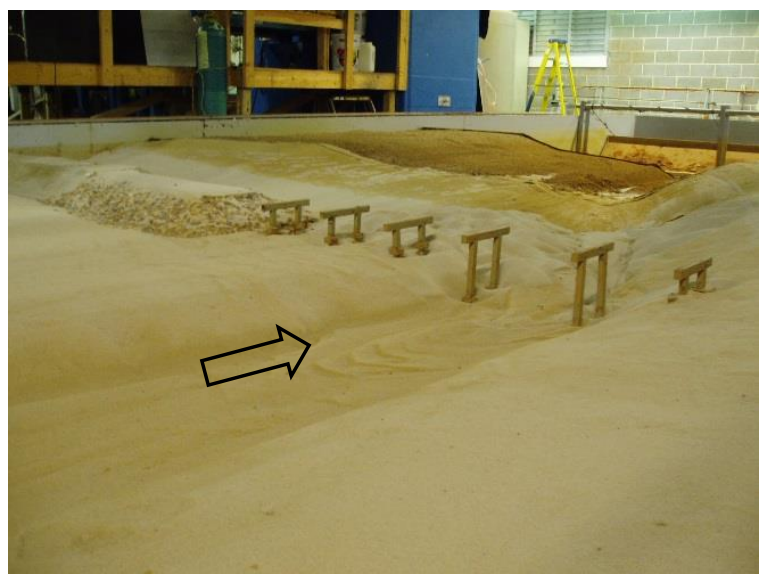

(b)

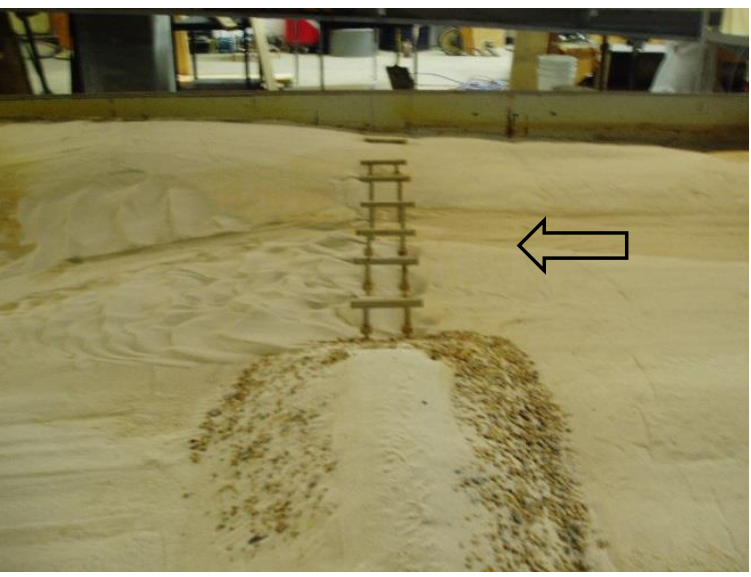

(d)

Run $1(\mathrm{~F}), \mathrm{Q}=1.04 \mathrm{cfs}$

When looking downstream,

(a) looking from left floodplain

(b) looking from right floodplain

(c) looking from right abutment

(d) looking from left abutment

(e) looking from upstream 


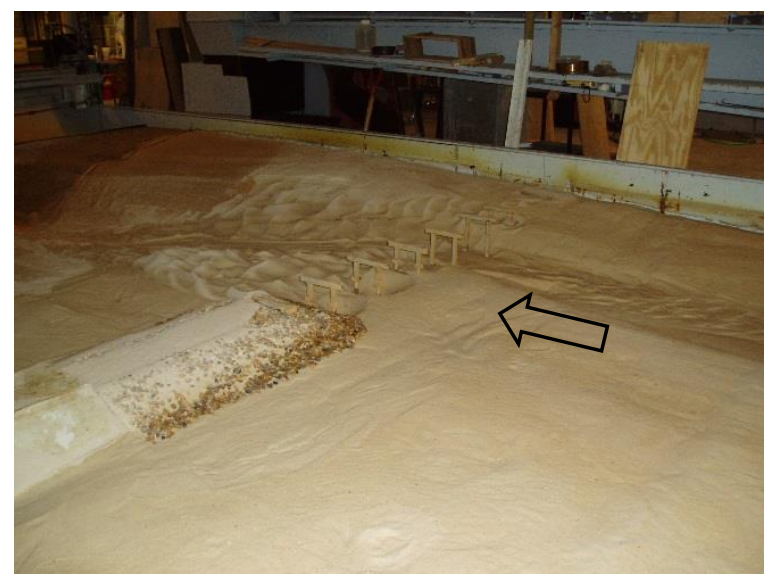

(a)

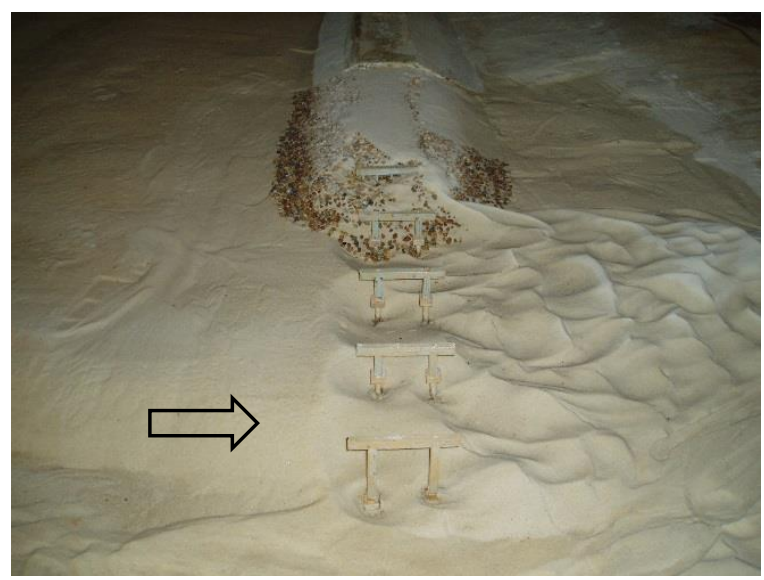

(c)

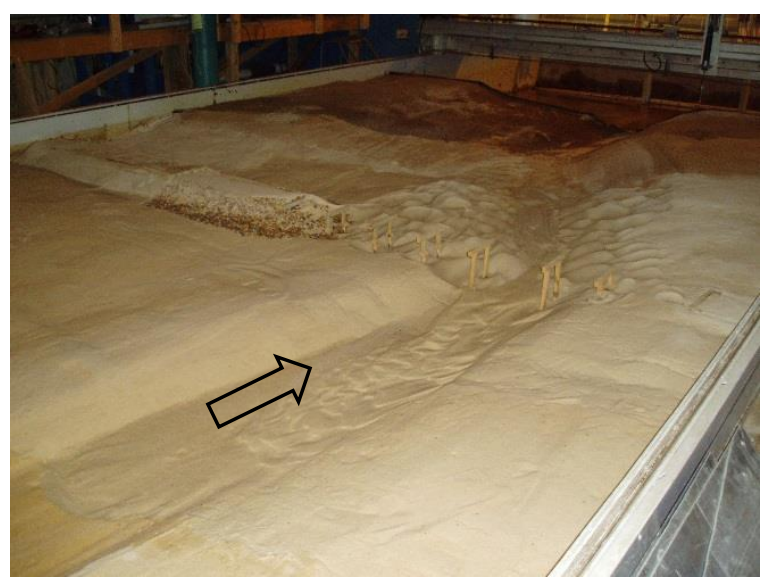

(e)

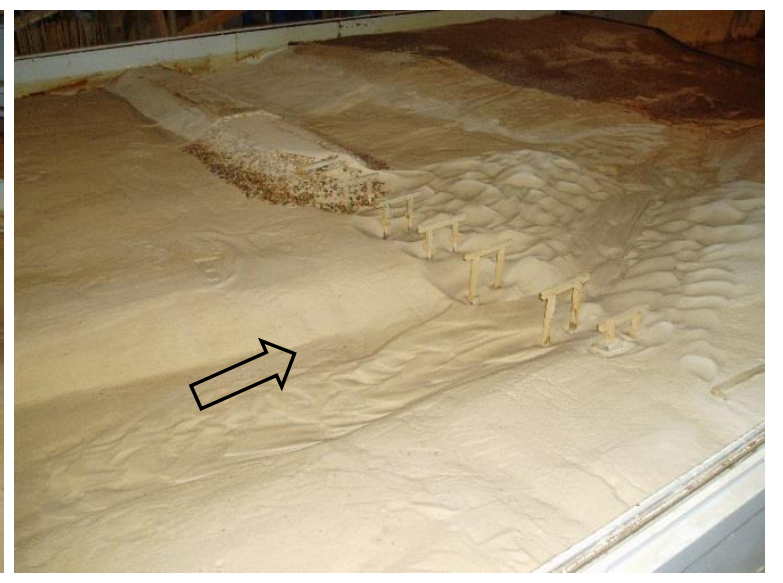

(b)

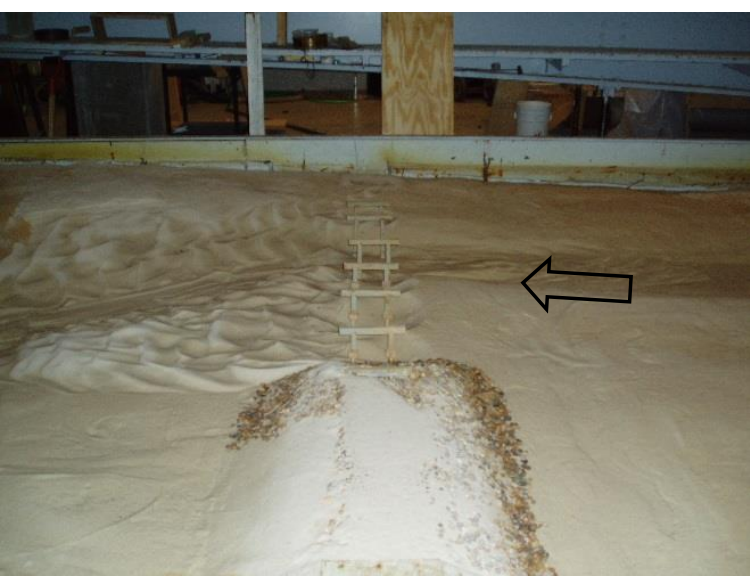

(d)

Run 2 (SO), Q = 1.33 cfs

When looking downstream,

(a) looking from left floodplain

(b) looking from right floodplain

(c) looking from right abutment

(d) looking from left abutment

(e) looking from upstream 


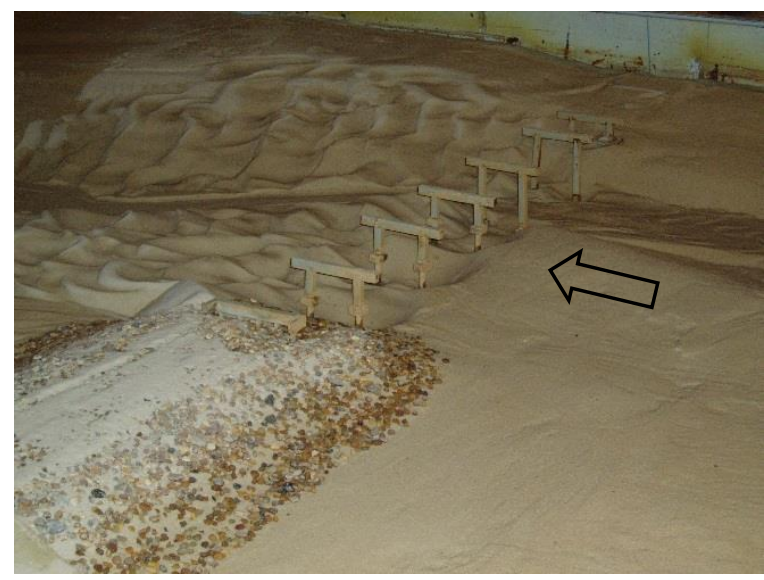

(a)

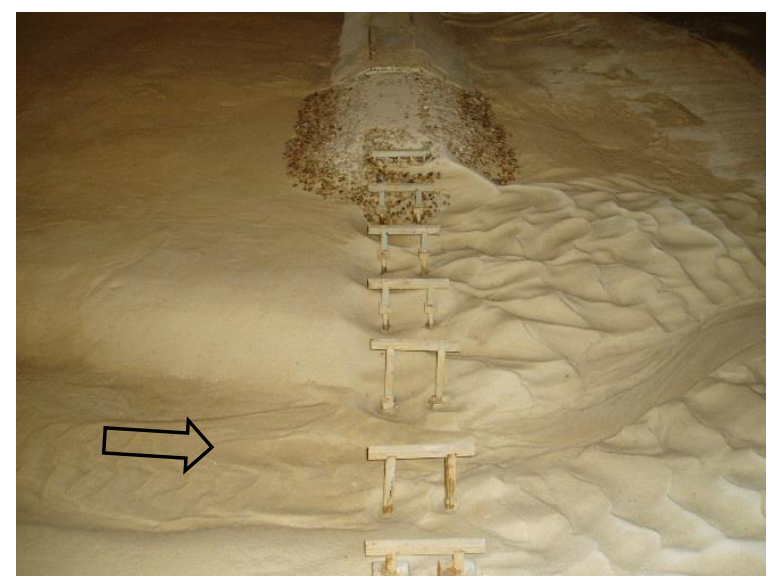

(c)

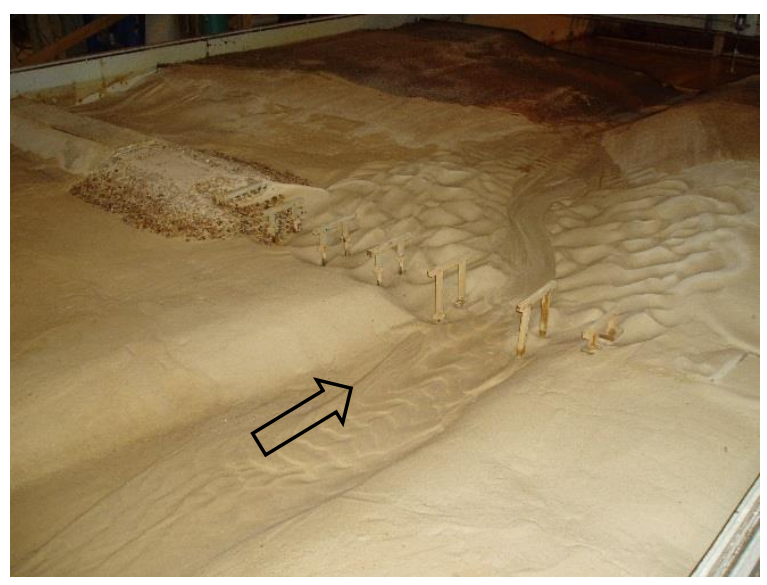

(e)

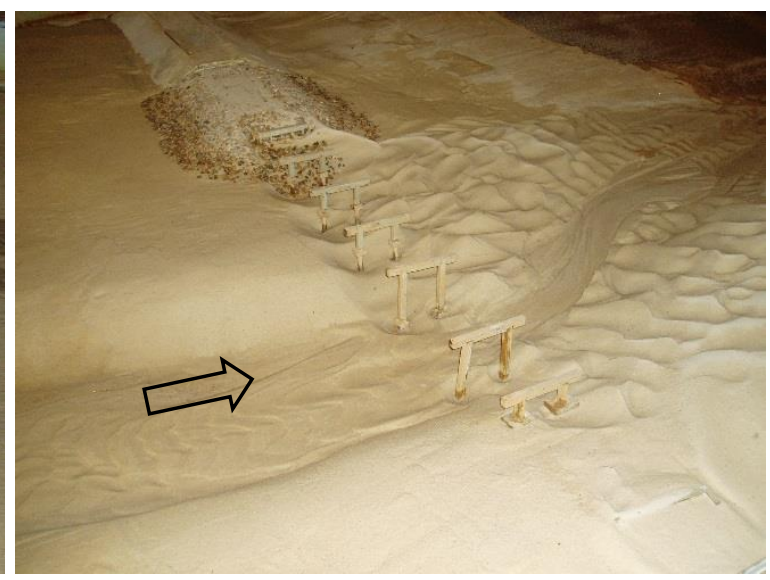

(b)

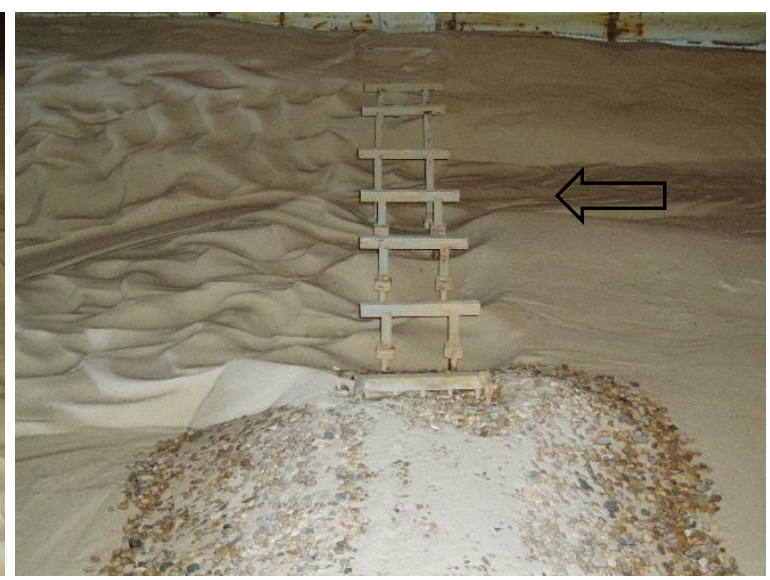

(d)

Run $3(\mathrm{OT}), \mathrm{Q}=1.86 \mathrm{cfs}$

When looking downstream,

(a) looking from left floodplain

(b) looking from right floodplain

(c) looking from right abutment

(d) looking from left abutment

(e) looking from upstream 


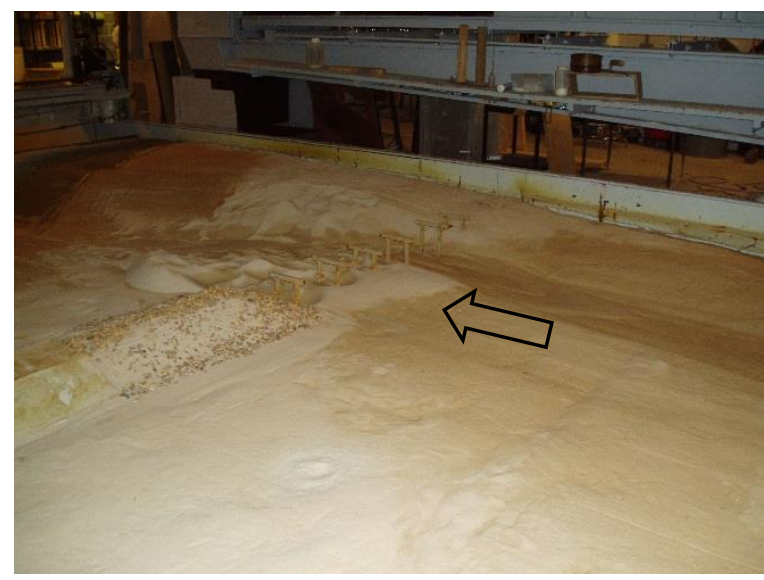

(a)

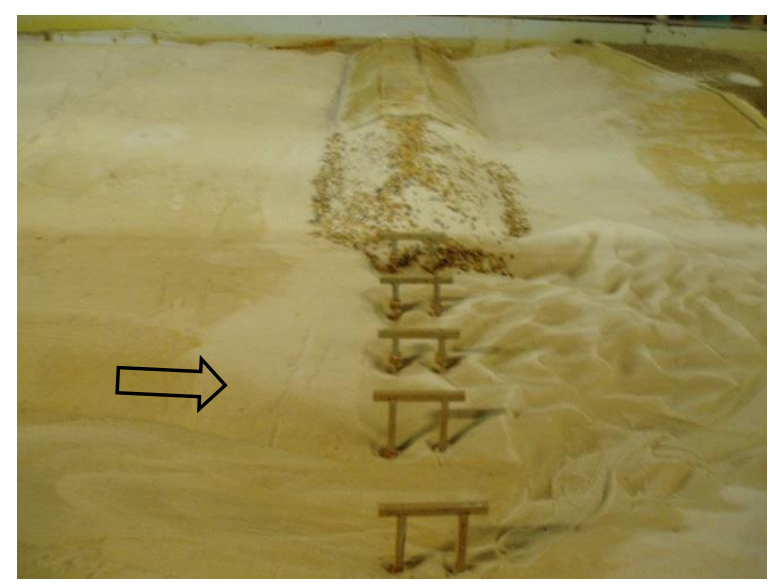

(c)

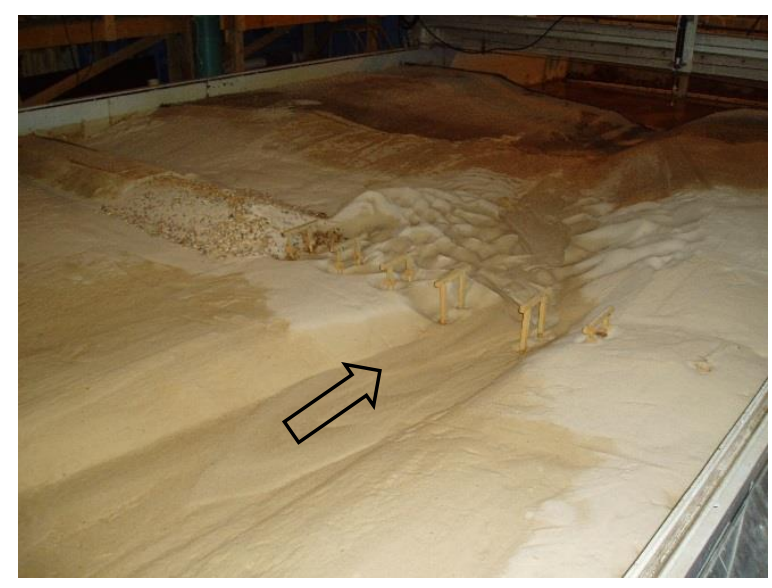

(e)

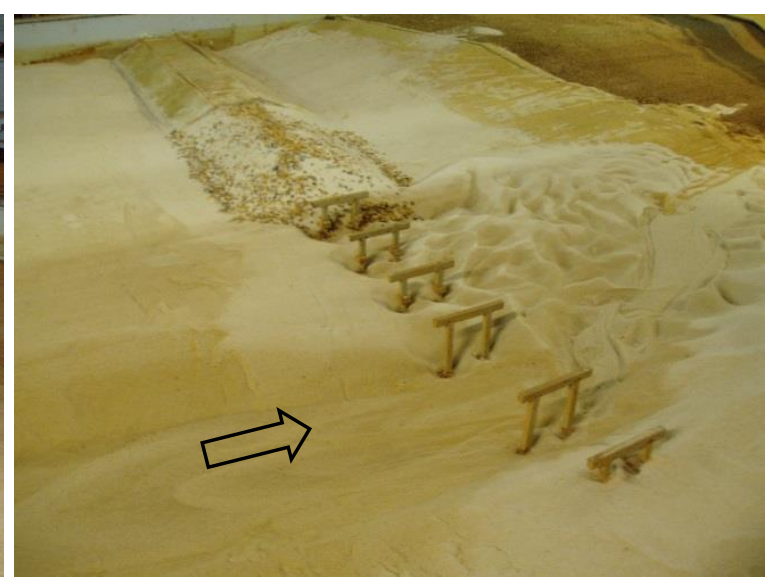

(b)

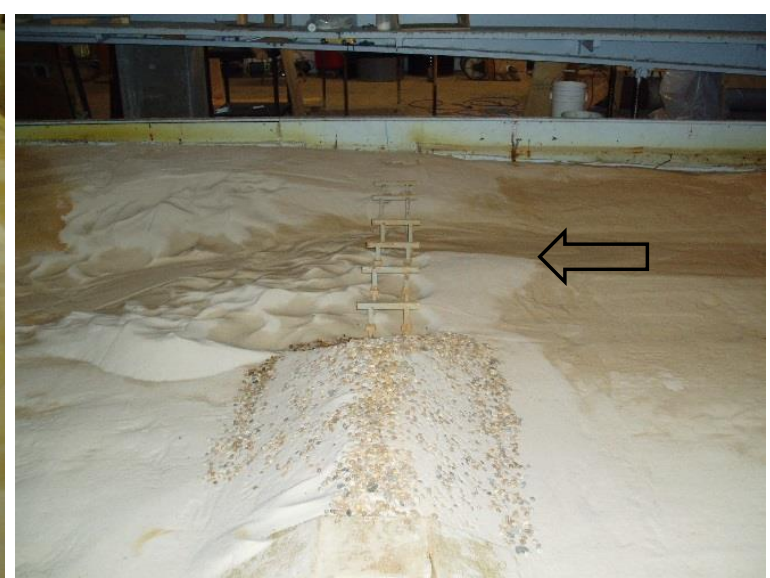

(d)

Run $4(\mathrm{~F}), \mathrm{Q}=1.61 \mathrm{cfs}$

When looking downstream,

(a) looking from left floodplain

(b) looking from right floodplain

(c) looking from right abutment

(d) looking from left abutment

(e) looking from upstream 


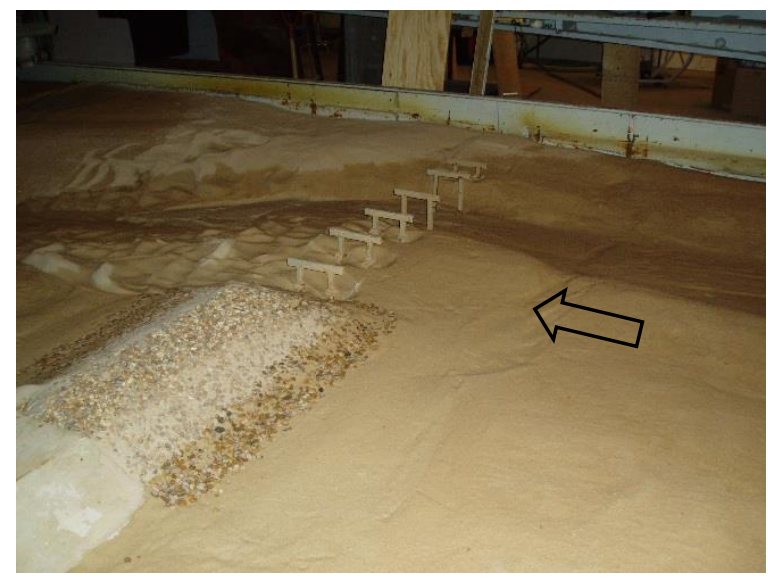

(a)

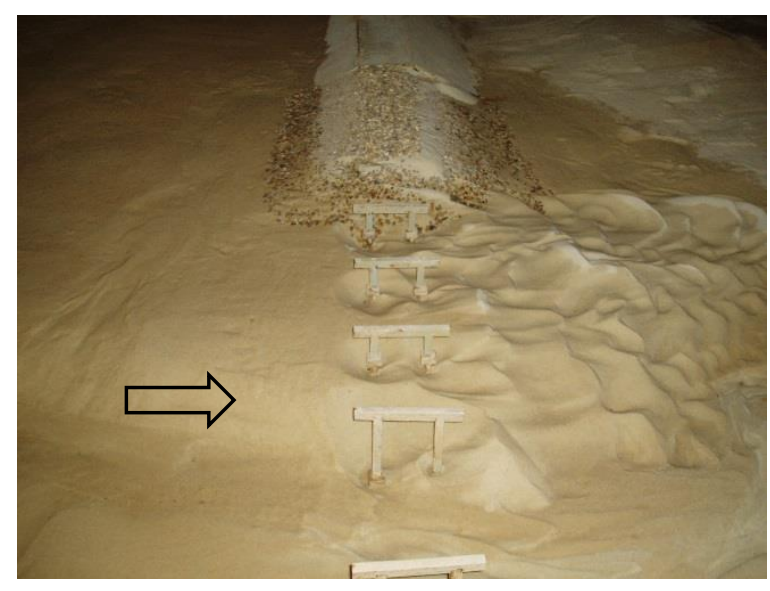

(c)

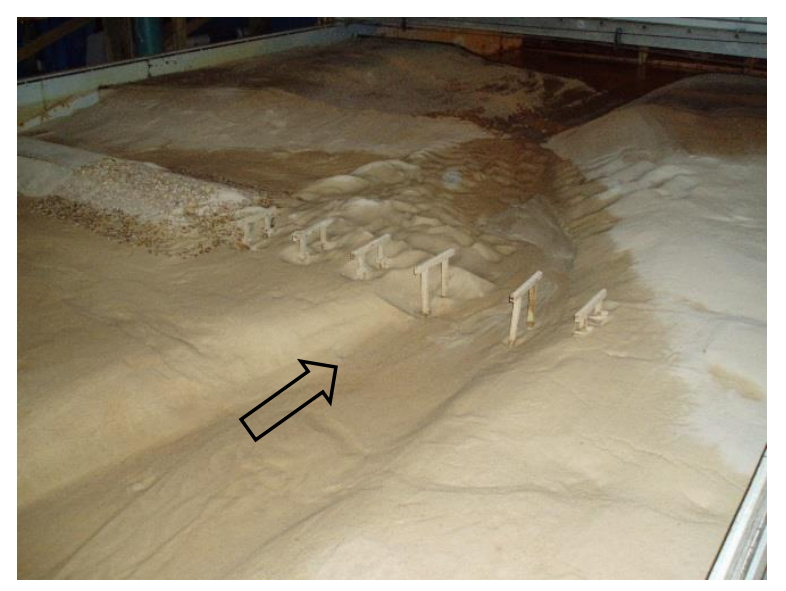

(e)

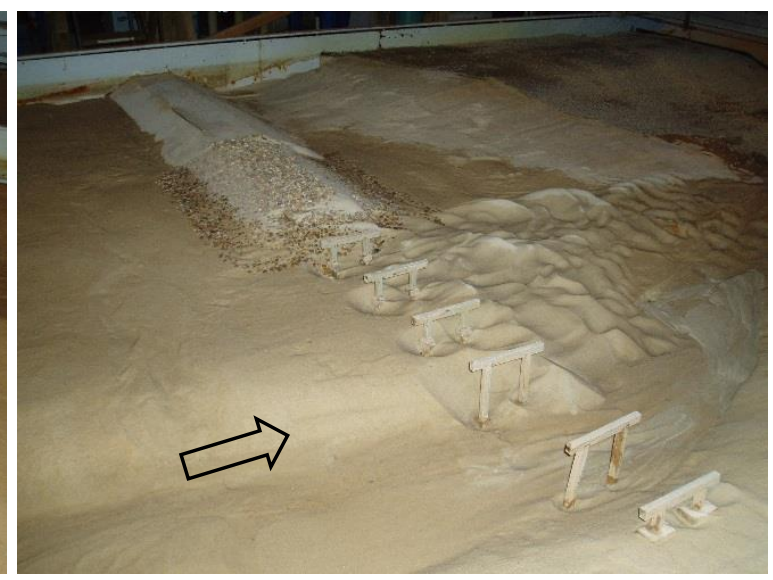

(b)

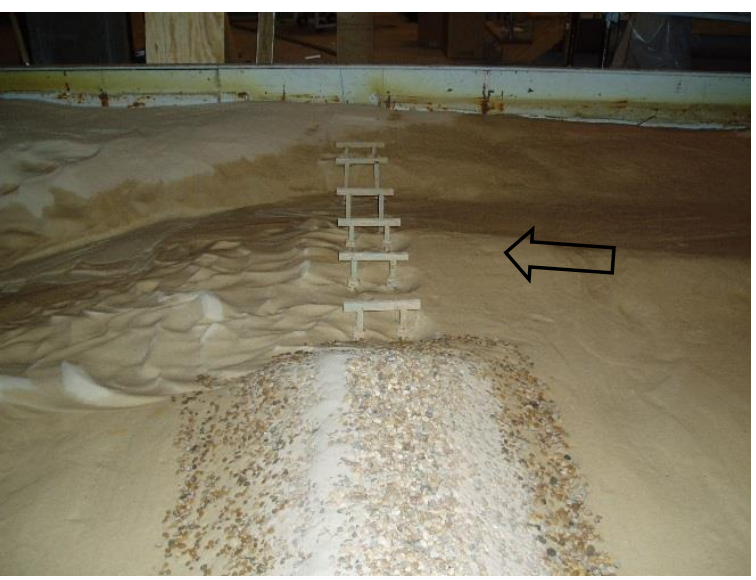

(d)

Run $5(\mathrm{~F}), \mathrm{Q}=1.86 \mathrm{cfs}$

When looking downstream,

(a) looking from left floodplain

(b) looking from right floodplain

(c) looking from right abutment

(d) looking from left abutment

(e) looking from upstream 


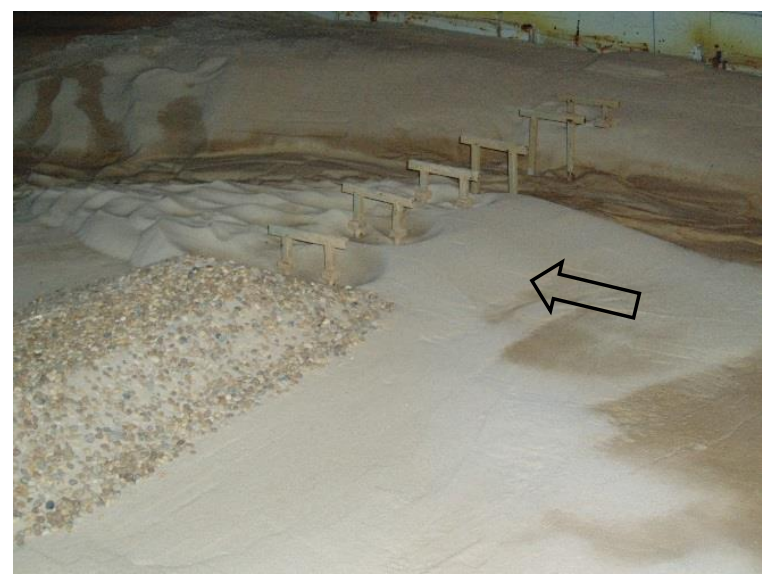

(a)

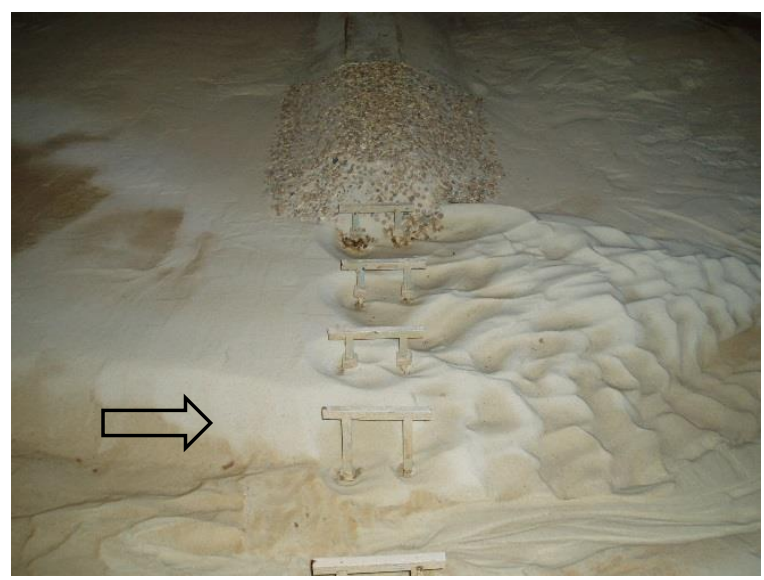

(c)

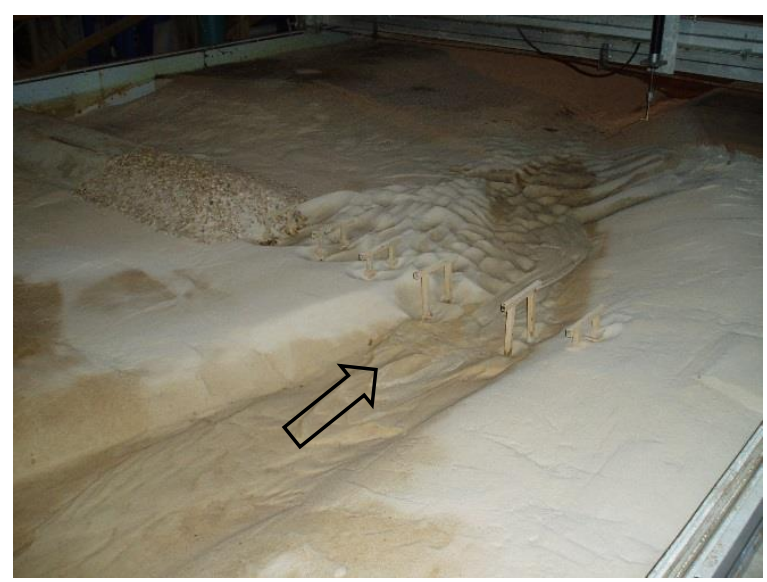

(e)

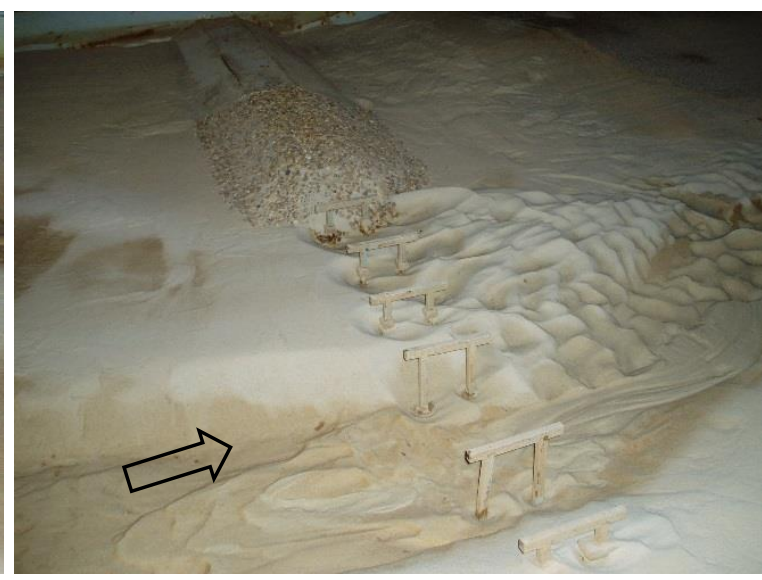

(b)

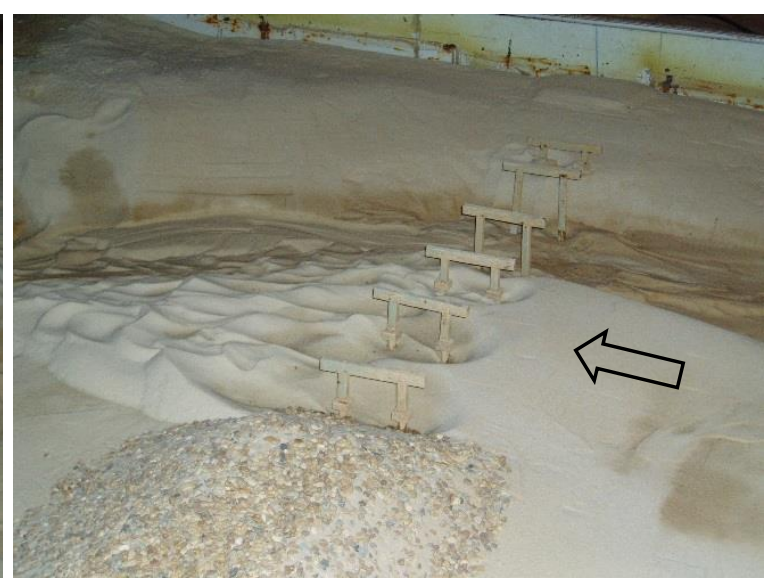

(d)

Run $6(\mathrm{~F}), \mathrm{Q}=1.33 \mathrm{cfs}$

When looking downstream,

(a) looking from left floodplain

(b) looking from right floodplain

(c) looking from right abutment

(d) looking from left abutment

(e) looking from upstream 


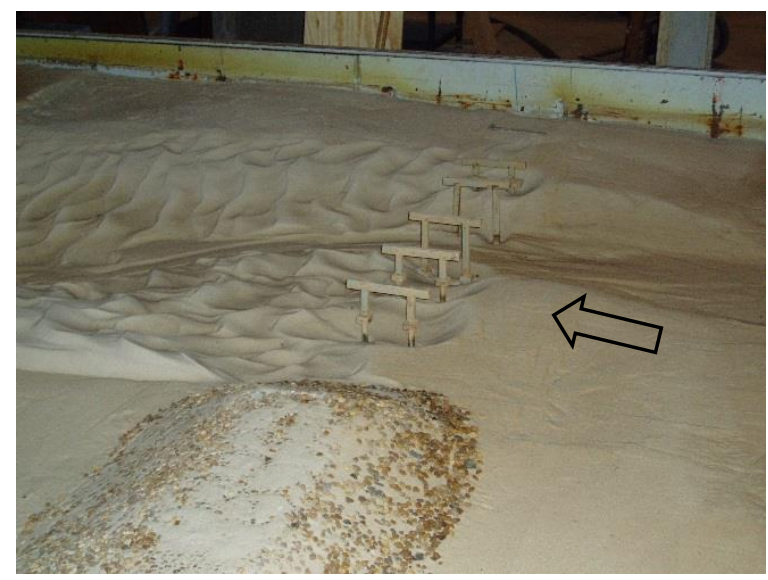

(a)

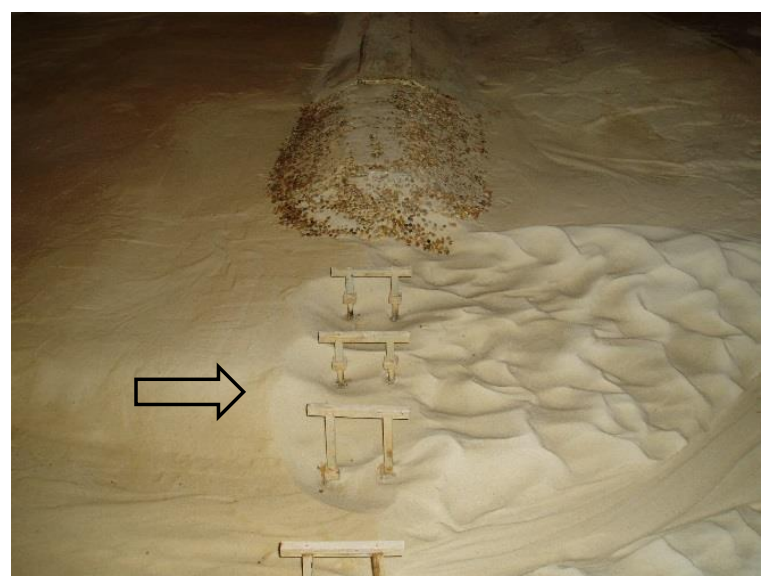

(c)

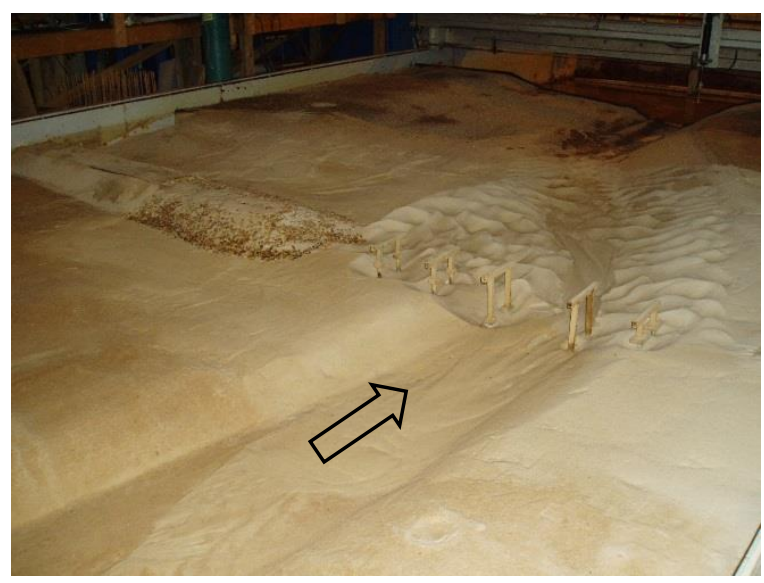

(e)

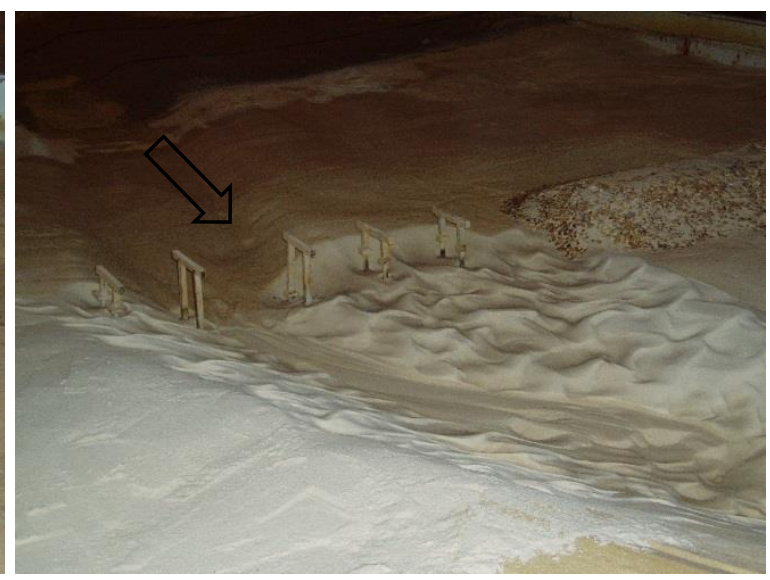

(b)

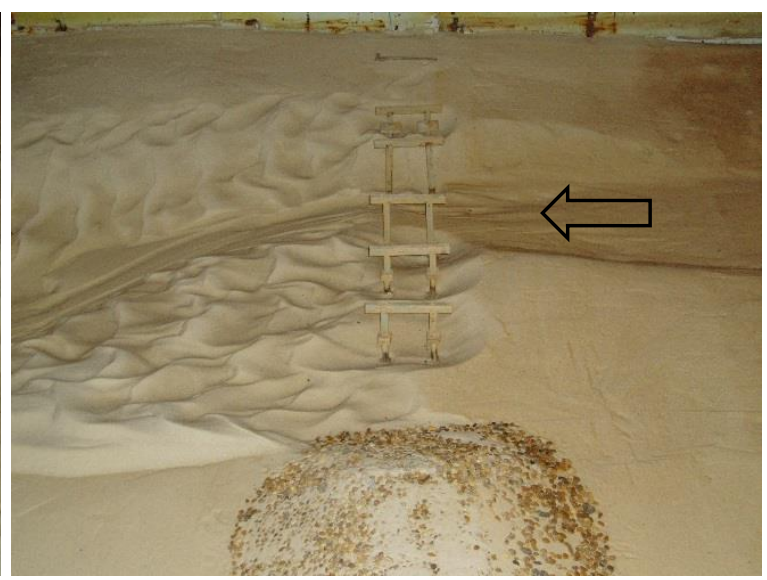

(d)

Run 7 (SO), Q = 1.33 cfs

When looking downstream,

(a) looking from left floodplain

(b) looking from downstream

(c) looking from right abutment

(d) looking from left abutment

(e) looking from upstream 


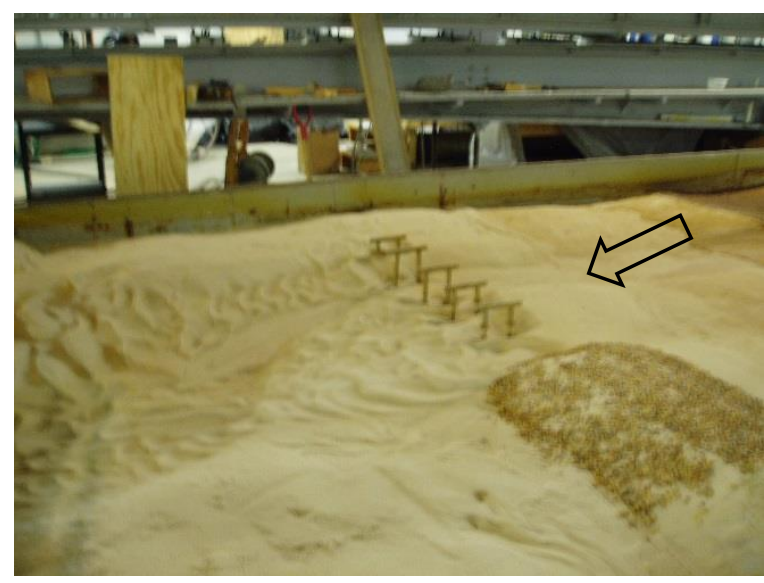

(a)

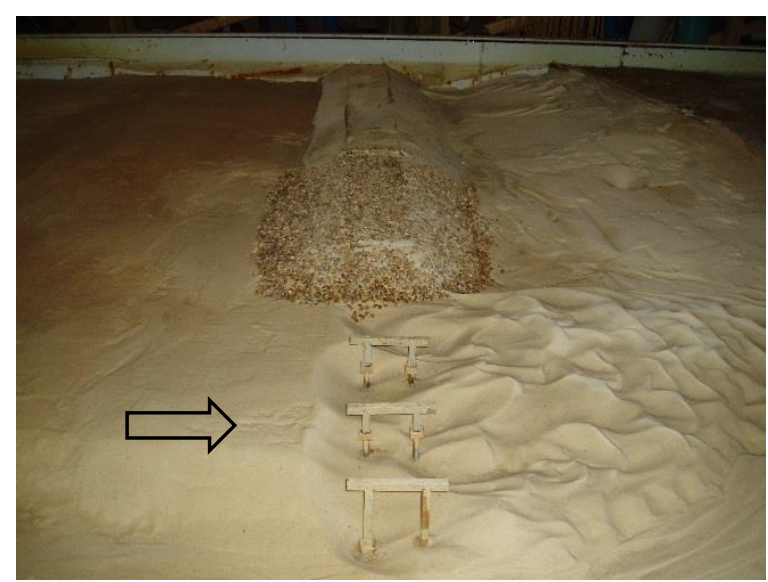

(c)

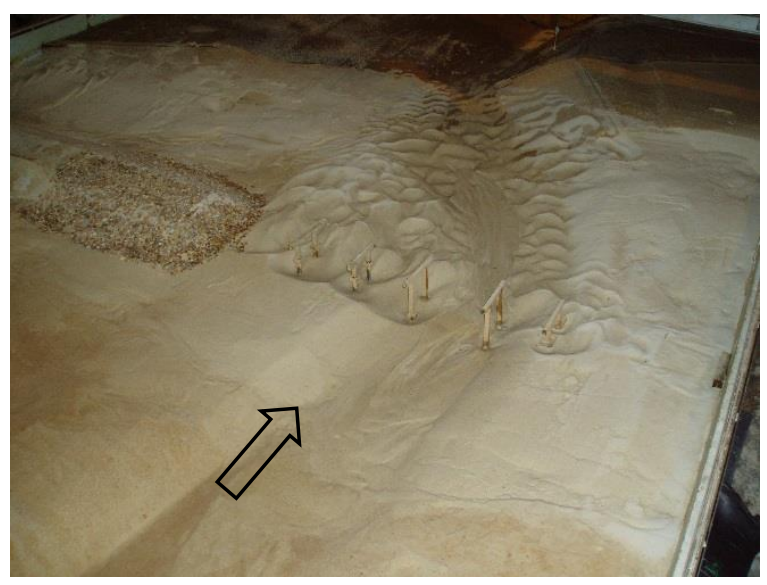

(e)

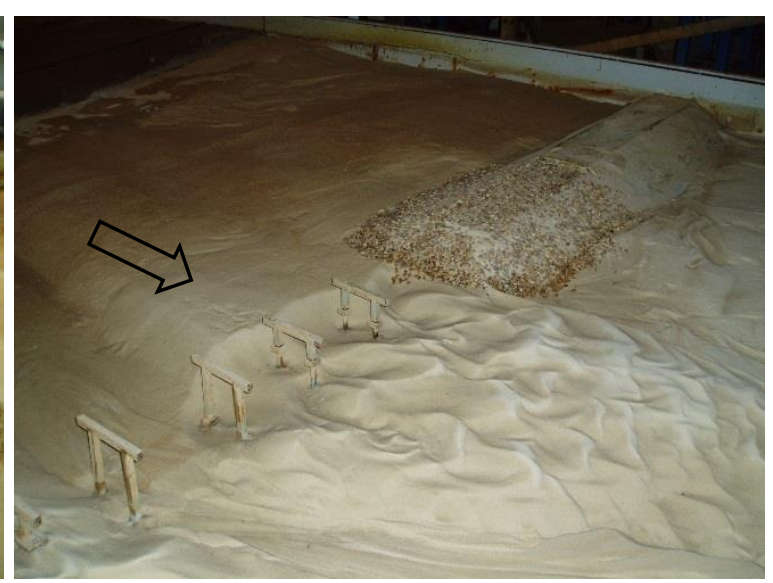

(b)

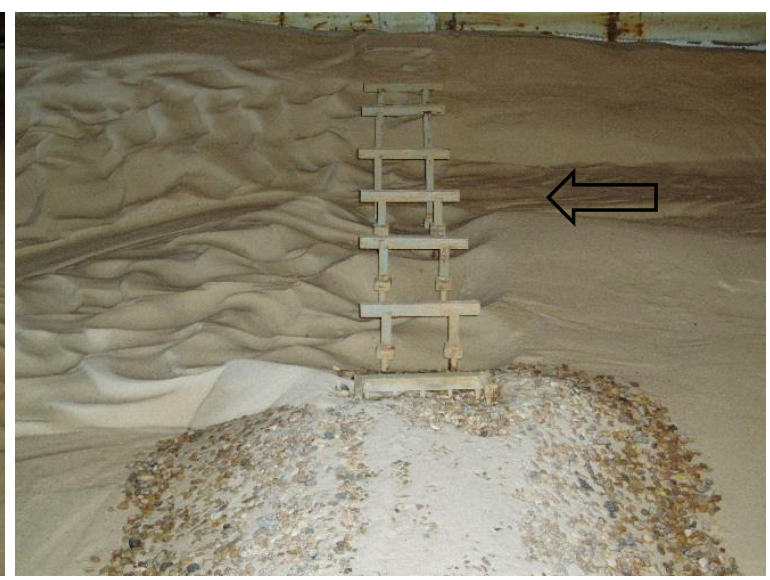

(d)

Run 8 (OT), Q = 1.86 cfs

When looking downstream,

(a) looking from downstream

(b) looking from dowstream

(c) looking from right abutment

(d) looking from left abutment

(e) looking from upstream 


\section{APPENDIX B}

\section{Maximum scour depth location cross-sections}




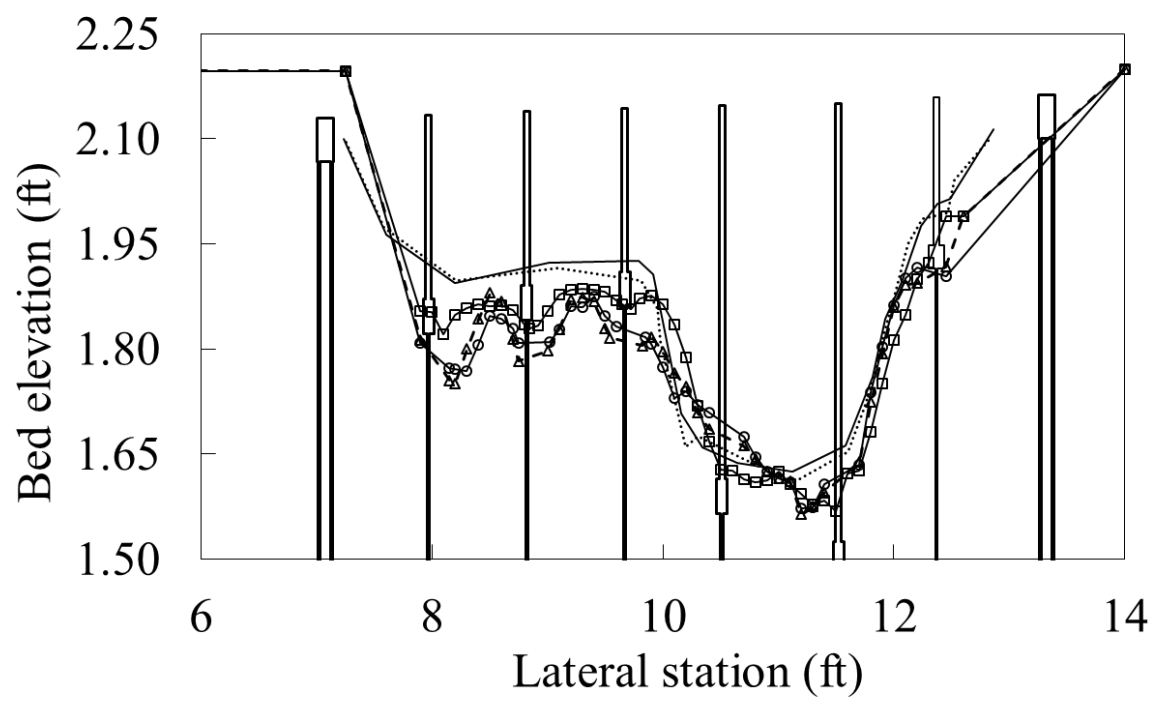

- Before scour @ U/S bridge section $\left(\mathrm{X}=45.56^{\prime}\right)$

....... Before scour@ $@$ D/S bridge section $\left(X=46.38^{\prime}\right)$

$\rightarrow$ After scour@ X=45.56'

--After scour@X=45.96'

$\rightarrow$ After scour@X=46.38'

Figure B.1. Location of maximum scour depth for run 1

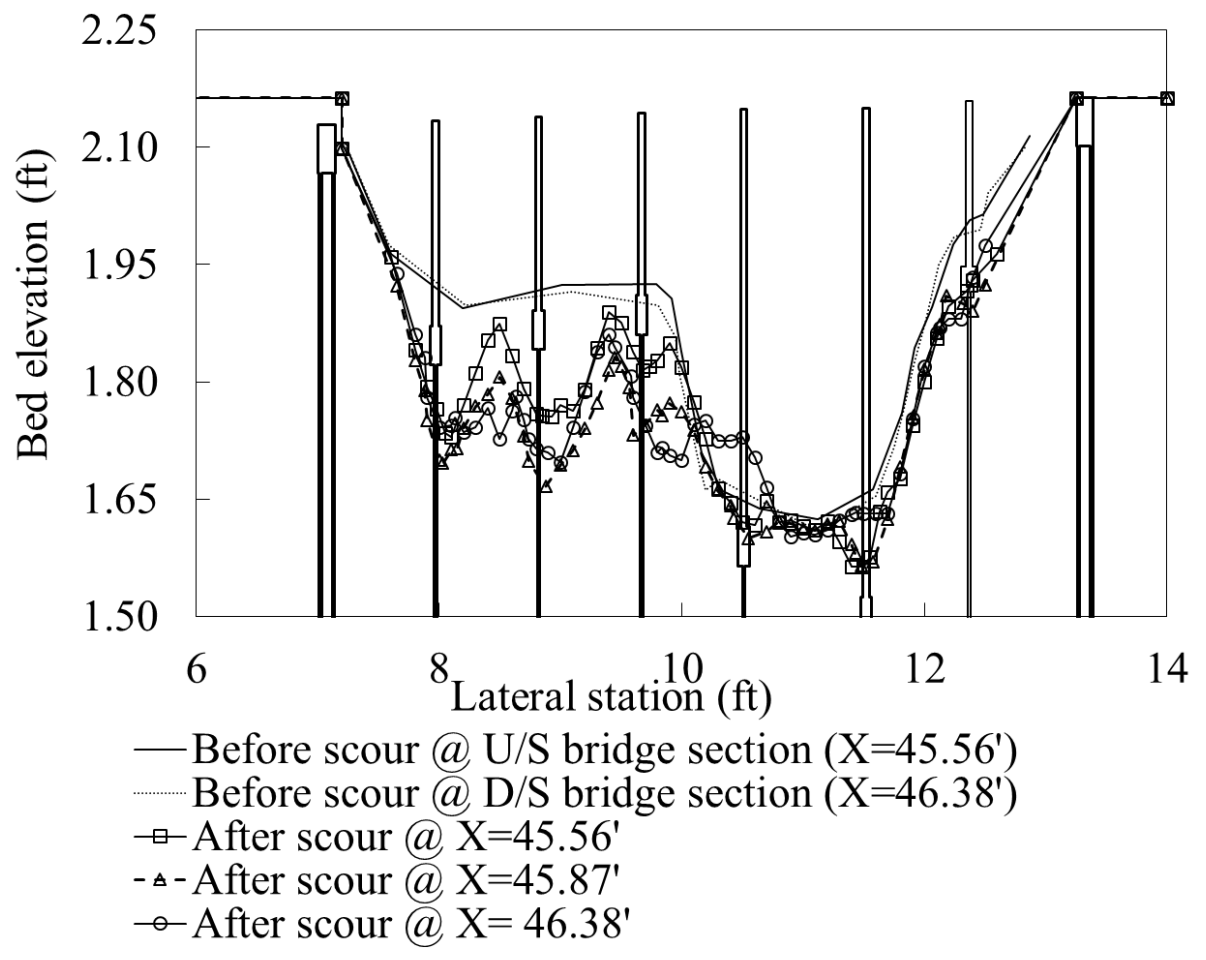

Figure B.2. Location of maximum scour depth for run 2 


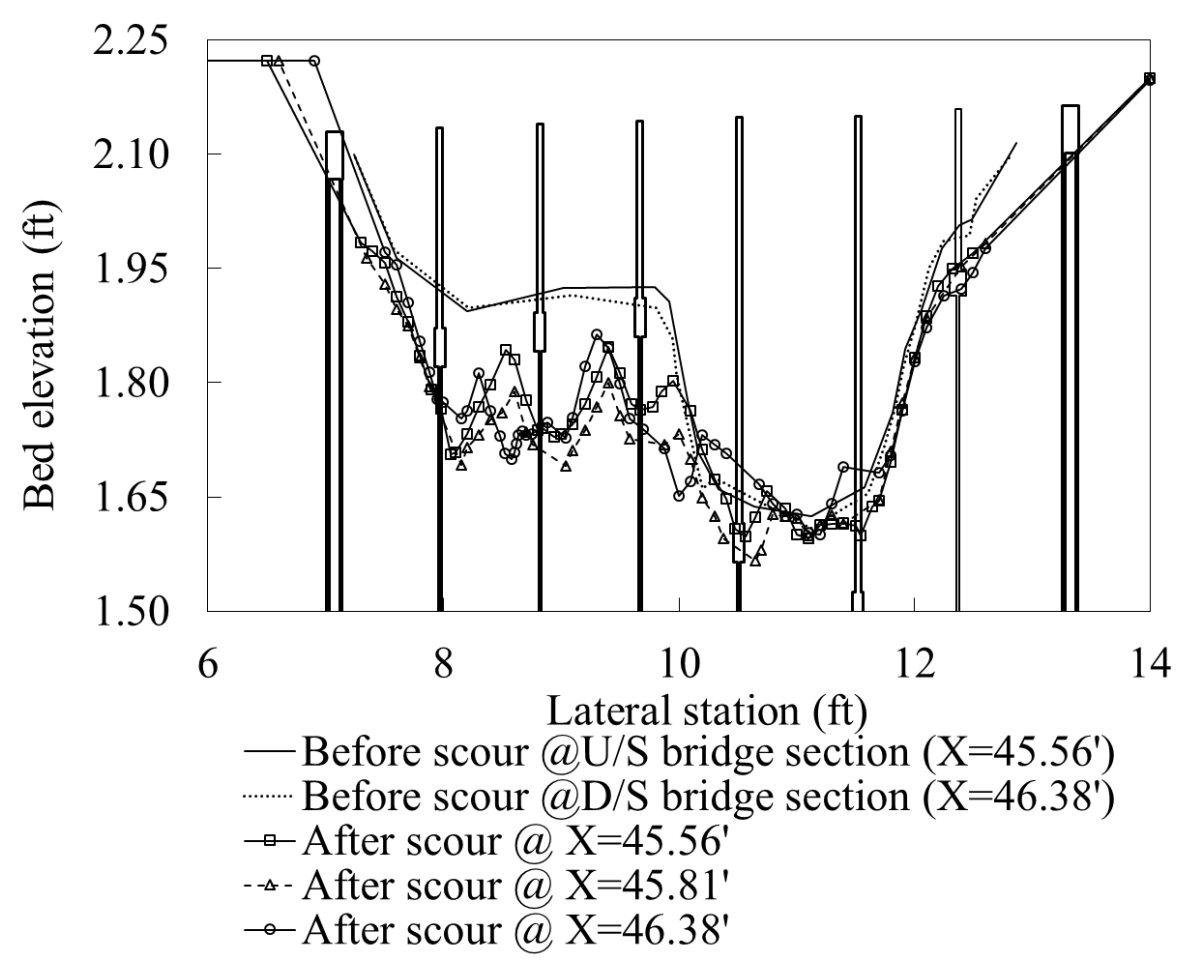

Figure B.3. Location of maximum scour depth for run 3

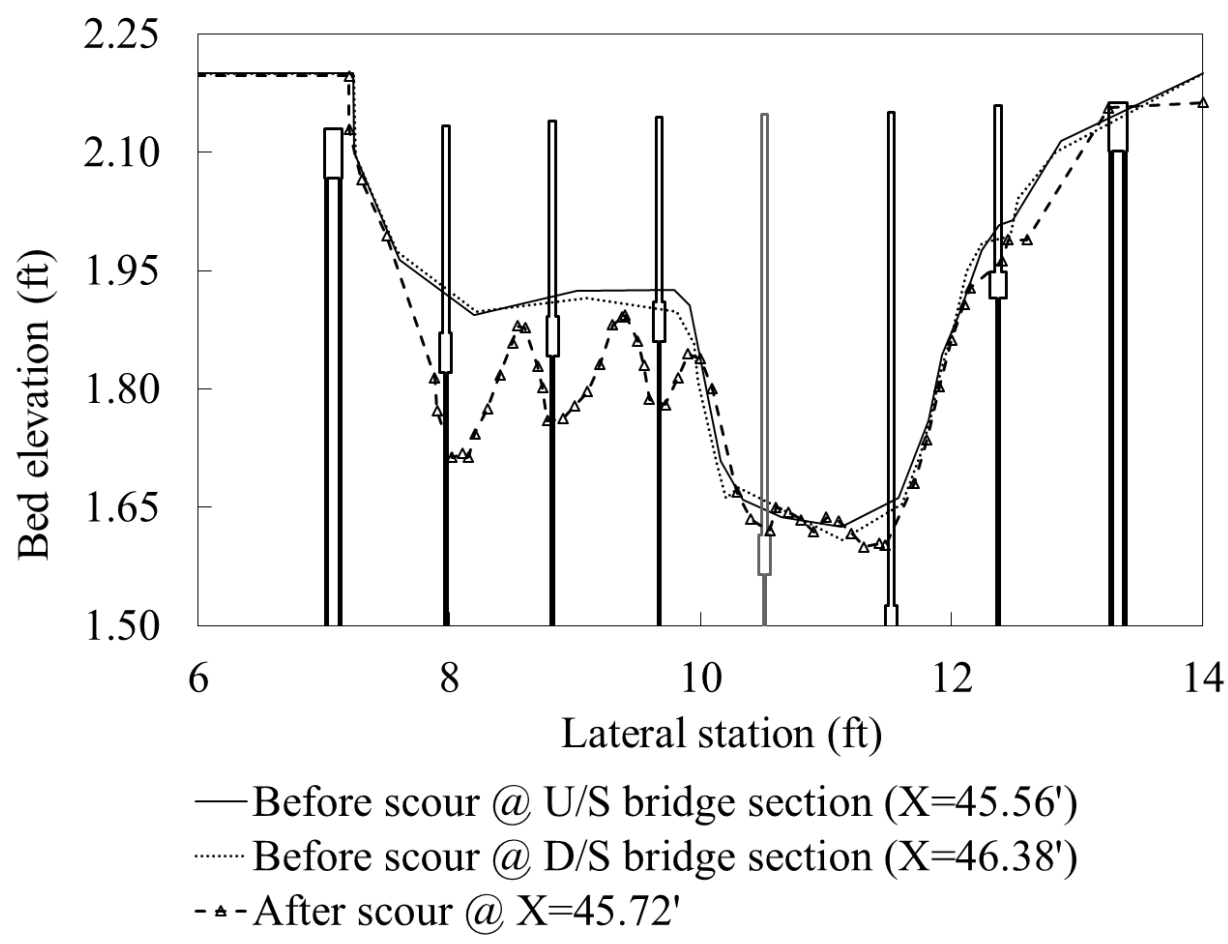

Figure B.4. Location of maximum scour depth for run 4 


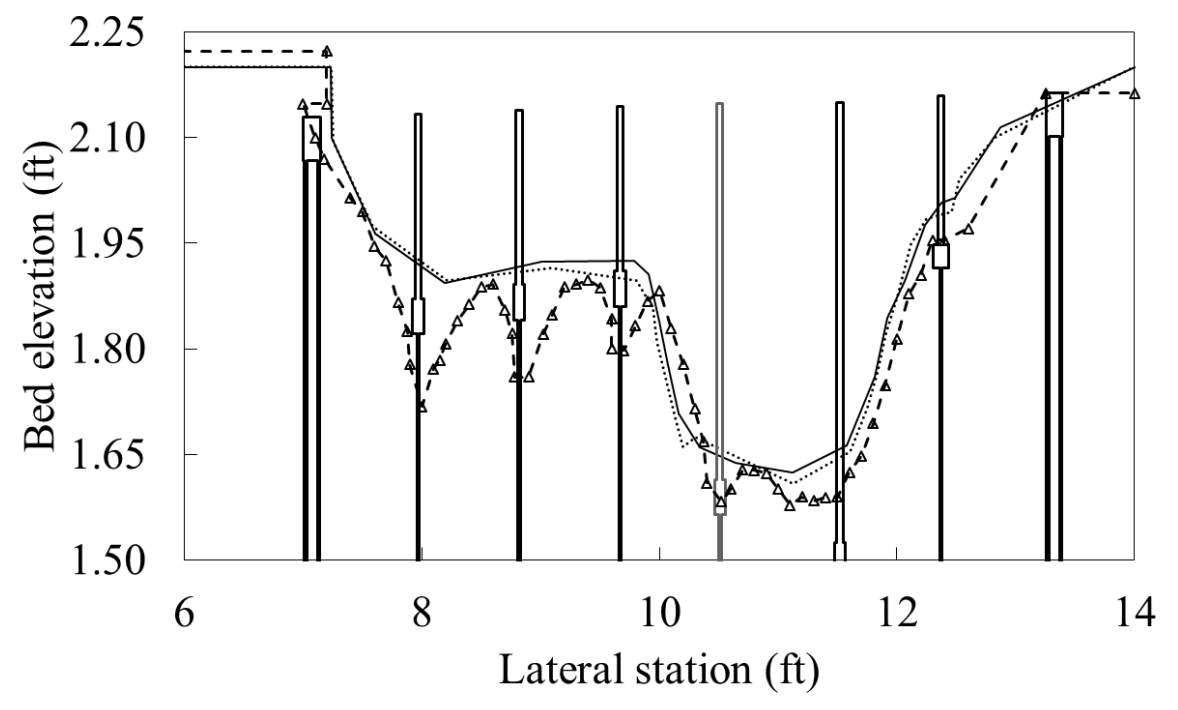

—Before scour@U/S bridge section $(X=45.56$ ')

........ Before scour@D/S bridge section $\left(X=46.38^{\prime}\right)$

- -After scour @ X=45.72'

Figure B.5. Location of maximum scour depth for run 5

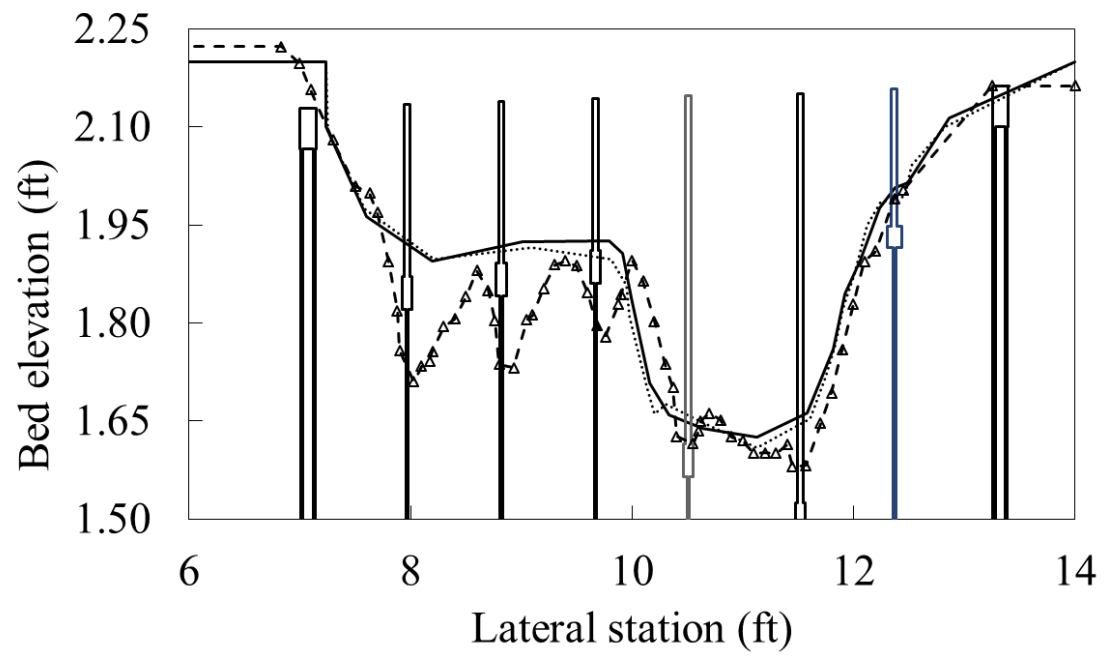

—Before scour @ U/S bridge section ( $\mathrm{X}=45.56$ ')

....... Before scour@ D/S bridge section (X=46.38')

--After scour@X=45.72'

Figure B.6. Location of maximum scour depth for run 6 


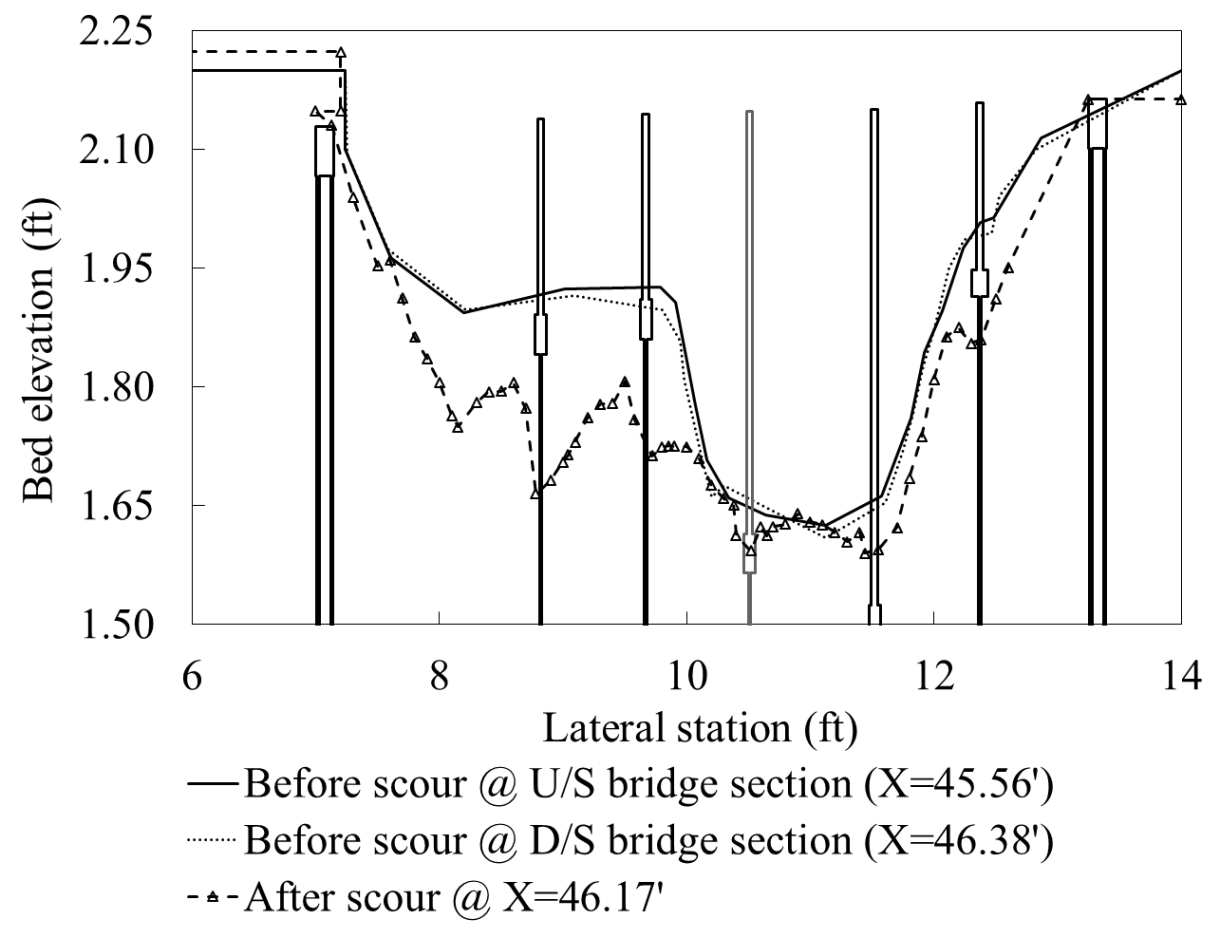

Figure B.7. Location of maximum scour depth for run 7

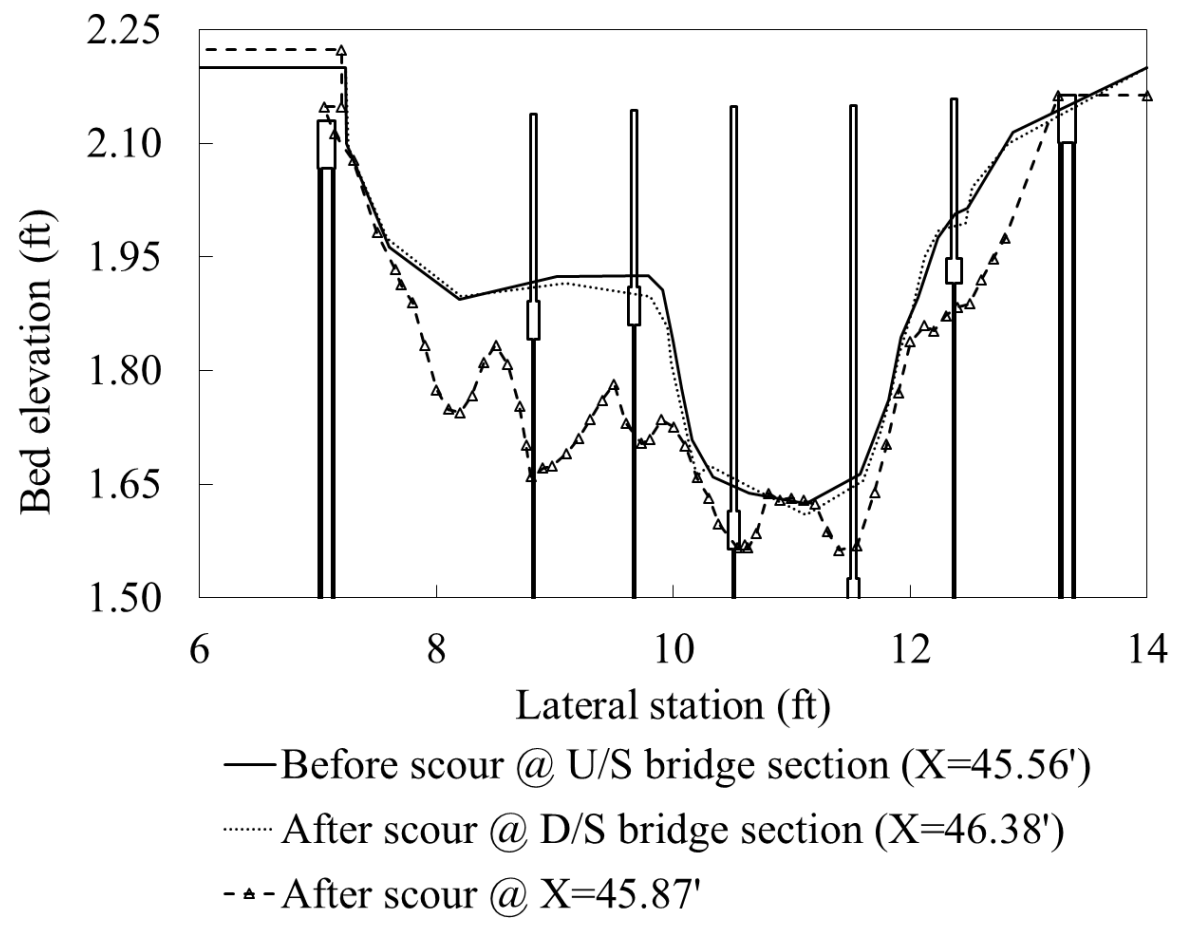

Figure B.8. Location of maximum scour depth for run 8 